\title{
Stereochemical Control of Skeletal Diversity
}

\author{
Jason K. Sello, Peter R. Andreana, Daesung Lee, Stuart L. Schreiber \\ Howard Hughes Medical Institute \& Institute of Chemistry and Cell Biology \\ Dept. of Chemistry and Chemical Biology \\ Harvard University, Cambridge, MA 02138
}

\section{Supporting Information}

Materials and Methods. All reagents were purchased from Aldrich with the exception of the ruthenium based olefin metathesis catalyst containing 1,3-dimesityl-4,5dihydroimidazol-2-ylidene, which was purchased from Strem and (S)-phenylglycinol, which was purchased from Fluka. Methylene chloride and tetrahydrofuran were passed through two activated alumina columns to remove impurities prior to use (as described in Organometallics 1996, 15, 1518-1520). Except as otherwise indicated, reactions were carried out under nitrogen with dry, freshly distilled solvents. Triethylamine was distilled from calcium hydride.

All reactions were monitored by thin layer chromatography using $0.25 \mathrm{~mm}$ E. Merck precoated silica gel 60 (particle size $0.040-0.063 \mathrm{~mm}$ ). Column chromatography performed using Merck $60 \AA$ (230-400 mesh ASTM) silica gel. Yields refer to chromatographically and spectroscopically pure compounds, except as noted. Concentration refers to the removal of solvent using a Büchi rotary evaporator followed by use of a vacuum pump at approximately 1 torr. 
Proton and carbon-13 NMR spectra were recorded on Varian Mercury 400, Varian Mercury 500 and Varian Unity/Inova 600 spectrometers. Proton and carbon-13 chemical shifts are reported in $\delta$ values relative to chloroform $(7.26 \mathrm{ppm}) . \quad 1 \mathrm{D}$ and 2D NMR experiments were configured using the GLIDE NMR software package VNMR 6.1B Software provided by Varian. Optical rotations were measured using a $2 \mathrm{~mL}$ cell with a $1 \mathrm{dm}$ path length on a JASCO DIP 370 digital polarimeter. High resolution mass spectra were obtained with JEOL AX-505 and JEOL SX-102 spectrometers.

X-Ray Crystallographic Data. All the crystal structure information for (+/-)-1, 6, 8, and 12 will be submitted to the Cambridge Crystal Structure Data Base following the instructions given by the Journal of Organic Letters.

\section{Experimental Section}

Tricyclic Cycloadduct (+/-) 1. Furfural (1.0 mL, $12.2 \mathrm{mmol})$ was dissolved in $20 \mathrm{~mL}$ of methanol. To this solution were added, 4-methoxybenzylamine (2.5 g, $18.3 \mathrm{mmol})$, fumaric acid monoethyl ester $(2.6 \mathrm{~g}, 18.3 \mathrm{mmol})$, and benzyl isocyanide $(1.5 \mathrm{~mL}, 12.2$ mmol). The reaction was judged to be complete after $48 \mathrm{~h}$ based on TLC analysis. After removal of solvent, the crude reaction mixture was applied directly to a silica gel column. The reaction yielded an 11:1 mixture of diastereomers. The major isomer $\mathbf{1},\left(\mathrm{R}_{\mathrm{f}}=0.73\right.$, 2:1 ethyl acetate:hexanes) was separated by column chromatography (silica gel, 2:1 hexanes:ethyl acetate) from the minor isomer $\left(\mathrm{R}_{\mathrm{f}}=0.79,2: 1\right.$ ethyl acetate:hexanes). The major isomer was isolated as a pale yellow oil in $90 \%$ yield. 1 was recrystallized from

ethyl acetate:hexanes (6:1). ${ }^{1} \mathrm{H}$ NMR $\left(\mathrm{CDCl}_{3}, 500 \mathrm{MHz}\right)$. See spectral data for 
assignment of the tricyclic lactam core. $\delta 7.33-7.28(\mathrm{~m}, 3 \mathrm{H}), 7.21(\mathrm{~d}, J=2.2 \mathrm{~Hz}, 2 \mathrm{H})$ $7.07(\mathrm{~d}, J=8.5 \mathrm{~Hz}, 2 \mathrm{H}), 6.97(\mathrm{bs}, \mathrm{NH}) ; 6.80(\mathrm{~d}, J=8.0 \mathrm{~Hz}, 2 \mathrm{H}), 6.39(\mathrm{~d}, J=5.5 \mathrm{~Hz}, 1 \mathrm{H})$, $6.28(\mathrm{dd}, J=1.5,6.0 \mathrm{~Hz}, 1 \mathrm{H}), 5.2(\mathrm{dd}, J=1.5,5.0 \mathrm{~Hz}, 1 \mathrm{H}), 4.84(\mathrm{~d}, J=15.5 \mathrm{~Hz}, 1 \mathrm{H})$, 4.46-4.37 (qd, $J=6.0,14.5 \mathrm{~Hz}, 2 \mathrm{H}), 4.12(\mathrm{~s}, 1 \mathrm{H}), 4.10(\mathrm{q}, J=7.0 \mathrm{~Hz}, 2 \mathrm{H}), 3.99(\mathrm{~d}, J=$ $15.0 \mathrm{~Hz}, 1 \mathrm{H}), 3.76(\mathrm{~s}, 3 \mathrm{H}), 3.40(\mathrm{t}, J=4.0 \mathrm{~Hz}, 1 \mathrm{H}) 3.07(\mathrm{~d}, J=3.5 \mathrm{~Hz}, 1 \mathrm{H}) 1.24(\mathrm{t}, J=$ $7.0 \mathrm{~Hz}, 3 \mathrm{H}) ;{ }^{13} \mathrm{C}$ NMR $\left(\mathrm{CDCl}_{3}, 125 \mathrm{MHz}\right) \delta 174.3,170.3,166.9,159.5,137.7,135.1$, $134.4,129.8,129.0,128.2,128.0,127.1,114.5,92.1,80.4,63.5,61.5,55.5,50.7,47.3$, 45.9, 44.1, 14.4. HRMS (EI) calculated for $\mathrm{C}_{27} \mathrm{H}_{28} \mathrm{~N}_{2} \mathrm{O}_{6}[\mathrm{M}+\mathrm{H}]$ : 477.2026, found: 477.2017.

Crystallographic data: orthorhombic single crystal $\left(0.10 \times 0.15 \times 0.15 \mathrm{~mm}^{3}\right.$, Space group Pccn, Unit cell constants $a=17.972(1), b=20.562(1), c=13.0049(7) \AA, \alpha=90^{\circ}, \beta=$ $\left.90^{\circ}, \gamma=90^{\circ}, V=4805.8(5) \AA^{3}, Z=4, D x=1.317 \mathrm{~g} / \mathrm{cm}^{3}\right)$. X-ray diffraction data were collected using a Bruker SMART CCD diffractometer equipped with an LT-2 lowtemperature apparatus at $213 \mathrm{~K}$. Data were measured using omega scans of $0.3^{\circ}$ per frame for 30 seconds. A total of 1271 frames were collected with a maximum resolution of $0.75 \AA$. Cell parameters were retrieved using SMART software and refined using SAINT on all observed reflections. Data reduction was performed with SAINT and the structures are solved by the direct method using the SHELXS-97 program incorporated in SHELXTL-PC V 5.10 and refined by least squares method on $\mathrm{F}^{2}$. The final agreement factors are $R(F)=0.0610, R \mathrm{w}(F)=0.1231$.

Allyl Carboxylate (+/-) 4. The tricyclic cycloadduct 1, (7.2 g, $15.1 \mathrm{mmol})$ was dissolved in $35 \mathrm{~mL}$ of THF. To this solution were added cesium hydroxide-monohydrate $(4.1 \mathrm{~g}$, 
$24.2 \mathrm{mmol})$ and allyl bromide $(7.9 \mathrm{~mL}, 90.8 \mathrm{mmol})$. The reaction mixture was stirred at ambient temperature for $8 \mathrm{~h}$. The reaction was quenched by the addition of $30 \mathrm{~mL}$ of $2 \mathrm{~N}$ $\mathrm{HCl}$. The reaction mixture was diluted with water. The resultant solution was extracted three times with hexanes:ethyl acetate (1:1). The combined organic layers were washed twice with a saturated solution of sodium bicarbonate and brine. The organic layer was then dried over magnesium sulfate. After filtration over a short pad of silica gel, the organic solvent was removed yielding the crude allylation product as a pale brown oil. The crude material was carried forward without purification.

The crude allylation product $(1.5 \mathrm{~g}, 2.8 \mathrm{mmol})$ was dissolved in $20 \mathrm{~mL}$ of THF. To this solution was added barium hydroxide-octahydrate $(2.7 \mathrm{~g}, 8.5 \mathrm{mmol})$. The reaction mixture was stirred for $12 \mathrm{~h}$ at ambient temperature. The reaction was quenched by the addition of $20 \mathrm{~mL}$ of $2 \mathrm{~N} \mathrm{HCl}$. The resultant milky white solution was treated with hydrochloric acid until the $\mathrm{pH}$ of the reaction solution was adjusted to 2 . A small volume of methanol $(5 \mathrm{~mL})$ was added to clarify the turbid aqueous solution. The aqueous solution was extracted five times with methylene chloride. The combined organic layers were washed with brine. The organic layer was then dried over magnesium sulfate and filtered over a short pad of silica gel. The residue was purified by flash chromatography (silica gel, 9:1 ethyl acetate:methanol) affording (+/-)-4 (90\% yield over both steps) as a pale yellow oil that foams under vacuum. ${ }^{1} \mathrm{H}$ NMR $\left(\mathrm{CDCl}_{3}, 500 \mathrm{MHz}\right)$. See spectrum (mixture of rotamers). ${ }^{13} \mathrm{C} \mathrm{NMR}\left(\mathrm{CDCl}_{3}, 100 \mathrm{MHz}\right) \delta 175.2,166.6,166.3,159.2,159.1$, 136.6, 135.7, 135.1, 132.8, 131.9, 131.1, 129.5, 129.3, 129.0, 128.9, 128.9, 128.8, 128.6, $128.1,128.0,127.9,126.7,126.5,120.0,117.8,114.2,114.1,91.7,80.5,80.4,59.5,59.4$, 
$55.3,55.20,51.3,49.4,49.2,48.9,48.3,46.4,45.2$. HRMS (EI) calculated for $\mathrm{C}_{28} \mathrm{H}_{28} \mathrm{~N}_{2} \mathrm{O}_{6}[\mathrm{M}+\mathrm{H}]:$ 489.2026, found: 489.2026.

\section{Typical Procedure for Synthesis of the $N$-(4-pentenoyl) Amino Alcohols}

$N$-4-pentenoyl-(1R,2R)-pseudoephedrine. To a solution of 4-pentenoic acid $(2.4 \mathrm{~g}$, $24.2 \mathrm{mmol})$, triethylamine $(9.7 \mathrm{~mL}, 72.6 \mathrm{mmol})$, 1-(3-dimethylaminopropyl)-3ethylcarbodiimide (EDC) (5.1 g, $26.6 \mathrm{mmol}$ ), and dimethylaminopyridine (DMAP) (591 $\mathrm{mg}, 4.8 \mathrm{mmol})$ in $\mathrm{CH}_{2} \mathrm{Cl}_{2}$ was added $(1 R, 2 R)$-pseudoephedrine (4.0 g, $\left.24.2 \mathrm{mmol}\right)$. The reaction mixture was stirred at ambient temperature for $12 \mathrm{~h}$. After removal of the solvent in vacuo, the residue was purified by flash chromatography (silica gel, 1:1 hexanes:ethyl acetate) afforded 4-pentenoyl-(1R,2R)-pseudoephedrine (77\%) as a colorless oil. ${ }^{1} \mathrm{H} \mathrm{NMR}\left(\mathrm{CDCl}_{3}, 500 \mathrm{MHz}\right)$ (mixture of rotamers). $\delta 7.38-7.35(\mathrm{~m}, 4 \mathrm{H})$, 7.29-7.26 (m, 1H), 5.89-5.83 (m, 1H), $5.56(\mathrm{bt}, J=5.9 \mathrm{~Hz}, \mathrm{NH}), 5.08(\mathrm{dd}, J=1.5,17.0$ $\mathrm{Hz}, 1 \mathrm{H}), 5.03(\mathrm{~d}, J=1.5 \mathrm{~Hz}, 1 \mathrm{H}), 4.58(\mathrm{t}, J=3.4 \mathrm{~Hz}, 1 \mathrm{H}), 4.56(\mathrm{bs}, \mathrm{OH}), 4.01(\mathrm{q}, 1 \mathrm{H})$ $2.93(\mathrm{~s}, 1 \mathrm{H}), 2.83(\mathrm{~s}, 2 \mathrm{H}), 2.48-2.33(\mathrm{~m}, 4 \mathrm{H}), 1.1(\mathrm{dd}, J=4.4 \mathrm{~Hz}, 2 \mathrm{H}), 0.99(\mathrm{dd}, J=4.4$ $\mathrm{Hz}, 1 \mathrm{H}) ;{ }^{13} \mathrm{C} \mathrm{NMR}\left(\mathrm{CDCl}_{3}, 100 \mathrm{MHz}\right) \delta 174.6,142.3,137.8,137.4,128.6,128.3,128.3$, $127.6,126.9,115.2,115.0,76.4,75.4,58.3,33.5,32.9,32.5,29.3,29.0,26.8,15.3,14.4$; Low Res. EIMS [M+H] calculated for $\mathrm{C}_{15} \mathrm{H}_{21} \mathrm{NO}_{2}$ : 248.2, found 248.0.

$N$-4-pentenoyl-(1S,2S)-2-amino-3-methoxy-1-phenyl-1-propanol. Yield: 64\%, white solid. ${ }^{1} \mathrm{H}$ NMR $\left(\mathrm{CDCl}_{3}, 500 \mathrm{MHz}\right) \delta 7.36-7.32(\mathrm{~m}, 3 \mathrm{H}), 7.28-7.25(\mathrm{~m}, 1 \mathrm{H}), 6.18(\mathrm{~d}, J=$ $7.8 \mathrm{~Hz}, \mathrm{NH}), 5.76-5.68(\mathrm{~m}, 1 \mathrm{H}), 5.01(\mathrm{dd}, J=1.5,17.1 \mathrm{~Hz}), 5.0(\mathrm{t}, J=3.4 \mathrm{~Hz}, 1 \mathrm{H}), 4.22-$ $4.19(\mathrm{~m}, 1 \mathrm{H}), 3.84(\mathrm{~d}, J=2.9 \mathrm{~Hz}, 1 \mathrm{H}), 3.44(\mathrm{qd}, J=3.4,9.8 \mathrm{~Hz}, 2 \mathrm{H}), 3.36(\mathrm{~s}, 3 \mathrm{H}), 2.33-$ 
$2.29(\mathrm{~m}, 2 \mathrm{H}), 2.27-2.24(\mathrm{~m}, 2 \mathrm{H}) ;{ }^{13} \mathrm{C} \mathrm{NMR}\left(\mathrm{CDCl}_{3}, 100 \mathrm{MHz}\right) \delta 173.1,141.1,136.8$ 128.3, 127.6, 125.9, 115.5, 74.4, 73.4, 59.2, 54.6, 35.7, 29.5; EIMS $[\mathrm{M}+\mathrm{H}]^{+}$calculated for $\mathrm{C}_{15} \mathrm{H}_{21} \mathrm{NO}_{3}: 264.3$, found 264.1.

$N$-4-pentenoyl-(S)-1-phenyl-2-aminoethanol. Yield: $67 \%$, colorless oil. ${ }^{1} \mathrm{H}$ NMR $\left(\mathrm{CDCl}_{3}, 500 \mathrm{MHz}\right) \delta 7.26(\mathrm{~d}, J=4.4 \mathrm{~Hz}, 2 \mathrm{H}), 7.22-7.17(\mathrm{~m}, 3 \mathrm{H}), 5.9(\mathrm{bs}, \mathrm{NH}), 5.75-5.67$ (m, 1H), $4.96(\mathrm{dd}, J=1.5,17.1 \mathrm{~Hz}, 1 \mathrm{H}), 4.91(\mathrm{dd}, J=1.5,10.2 \mathrm{~Hz}, 1 \mathrm{H}), 4.76-4.73(\mathrm{~m}$, $1 \mathrm{H}), 3.6(\mathrm{dq}, J=2.9,6.8 \mathrm{~Hz}, 1 \mathrm{H}), 3.43(\mathrm{bs}, 1 \mathrm{H}), 3.24(\mathrm{qd}, J=1.5,6.8 \mathrm{~Hz}, 2 \mathrm{H}), 2.27(\mathrm{qd}$, $J=1.5,7.8 \mathrm{~Hz}, 2 \mathrm{H}), 2.19(\mathrm{t}, J=7.8 \mathrm{~Hz}, 2 \mathrm{H}) ;{ }^{13} \mathrm{C} \mathrm{NMR}\left(\mathrm{CDCl}_{3}, 100 \mathrm{MHz}\right) \delta 173.8$, 141.8, 136.8, 128.4, 127.7, 125.8, 115.6, 73.2, 47.4, 35.6, 29.5; EIMS $[\mathrm{M}+\mathrm{H}]^{+}$calculated for $\mathrm{C}_{13} \mathrm{H}_{17} \mathrm{NO}_{2}: 220.1$, found 219.9.

$\boldsymbol{N}$-4-pentenoyl-(S)-1-aminopropanol. Yield: $70 \%$, pale yellow oil. ${ }^{1} \mathrm{H}$ NMR $\left(\mathrm{CDCl}_{3}\right.$, $500 \mathrm{MHz}) \delta 6.10(\mathrm{bs}, \mathrm{NH}), 5.86-5.78(\mathrm{~m}, 1 \mathrm{H}), 5.07(\mathrm{dd}, J=1.5,17.1 \mathrm{~Hz}, 1 \mathrm{H}), 5.01(\mathrm{dd}, J$ $=1.95,10.3 \mathrm{~Hz}, 1 \mathrm{H}), 3.93-3.87(\mathrm{~m}, 1 \mathrm{H}), 3.43(\mathrm{dq}, J=2.9,6.8 \mathrm{~Hz}, 2 \mathrm{H}), 3.13-3.07(\mathrm{~m}$, $1 \mathrm{H}), 2.9(\mathrm{~d}, J=4.4 \mathrm{~Hz}, 1 \mathrm{H}),(2.39(\mathrm{qd}, J=1.5,6.8 \mathrm{~Hz}, 2 \mathrm{H}), 2.30(\mathrm{t}, J=7.3 \mathrm{~Hz}, 2 \mathrm{H}), 1.43$ $(\mathrm{d}, J=6.4 \mathrm{~Hz}, 3 \mathrm{H}) ;{ }^{13} \mathrm{C} \mathrm{NMR}\left(\mathrm{CDCl}_{3}, 100 \mathrm{MHz}\right) \delta 173.6,136.7,115.5,66.9,46.9,35.6$, 29.5, 20.7; EIMS [M+H] $]^{+}$calculated for $\mathrm{C}_{8} \mathrm{H}_{15} \mathrm{NO}_{2}: 158.1$, found 157.9.

$N$-4-pentenyl-(1S,2R)-norephedrine. Yield: $78 \%$, colorless oil. ${ }^{1} \mathrm{H}$ NMR $\left(\mathrm{CDCl}_{3}, 500\right.$ MHz) $\delta 7.38-7.26(\mathrm{~m}, 5 \mathrm{H}), 5.87-5.79(\mathrm{~m}, 1 \mathrm{H}), 5.56(\mathrm{~d}, J=5.9 \mathrm{~Hz}, \mathrm{NH}), 5.08(\mathrm{dd}, J=1.5$, $17.0 \mathrm{~Hz}, 2 \mathrm{H}), 5.03(\mathrm{dd}, J=1.5,9.8 \mathrm{~Hz}, 2 \mathrm{H}), 4.85(\mathrm{t}, J=3.4 \mathrm{~Hz}, 1 \mathrm{H}), 4.35(\mathrm{dq}, J=2.9$, $7.3 \mathrm{~Hz}, 1 \mathrm{H}), 3.54(\mathrm{~d}, J=4.4 \mathrm{~Hz}, 1 \mathrm{H}), 2.4(\mathrm{q}, J=6.8 \mathrm{~Hz}, 2 \mathrm{H}), 2.9(\mathrm{t}, J=1.5 \mathrm{~Hz}, 2 \mathrm{H}), 1.02$ 
$(\mathrm{d}, J=6.8 \mathrm{~Hz}, 3 \mathrm{H}) ;{ }^{13} \mathrm{C} \mathrm{NMR}\left(\mathrm{CDCl}_{3}, 100 \mathrm{MHz}\right) \delta 173.1,140.7,136.8,128.1,127.4$, 126.3, 115.7, 51.0, 35.7, 29.5, 14.4; EIMS $[\mathrm{M}+\mathrm{H}]^{+}$calculated for $\mathrm{C}_{14} \mathrm{H}_{19} \mathrm{NO}_{2}:$ 234.1, found 233.9.

$N$-4-pentenyl-2-amino-2-methyl-1-propanol. Yield: 52\%, colorless oil. ${ }^{1} \mathrm{H}$ NMR $\left(\mathrm{CDCl}_{3}, 500 \mathrm{MHz}\right) \delta 5.85-5.77(\mathrm{~m}, 1 \mathrm{H}) 5.56(\mathrm{bs}, \mathrm{NH}), 5.07(\mathrm{dd}, J=1.95,17 \mathrm{~Hz}, 2 \mathrm{H})$, $5.03(\mathrm{dd}, J=1.0,10.3 \mathrm{~Hz}, 2 \mathrm{H}), 4.87(\mathrm{~d}, J=5.9 \mathrm{~Hz}, \mathrm{OH}), 3.57(\mathrm{~d}, J=5.9 \mathrm{~Hz}, 2 \mathrm{H}), 2.37$ $(\mathrm{dt}, J=6.8,7.3 \mathrm{~Hz}, 2 \mathrm{H}), 2.25(\mathrm{t}, J=7.8 \mathrm{~Hz}, 2 \mathrm{H}), 1.28(\mathrm{~s}, 6 \mathrm{H}) ;{ }^{13} \mathrm{C} \mathrm{NMR}\left(\mathrm{CDCl}_{3}, 100\right.$ MHz) $\delta 173.4,136.7,115.8,70.7,56.1,36.2,29.7,24.6$; EIMS $[\mathrm{M}+\mathrm{H}]^{+}$calculated for $\mathrm{C}_{9} \mathrm{H}_{17} \mathrm{NO}_{2}:$ : 172.1, found 171.9 .

\section{Typical Procedures for Synthesis of Metathesis Substrates}

Protocol A: Metathesis substrates 2 and 3. Racemic 4 (1.7 g, 3.4 mmol) was dissolved in $10 \mathrm{~mL}$ of $\mathrm{CH}_{2} \mathrm{Cl}_{2}$. To this solution was added benzotriazol-1-yloxy-tris(dimethylamino)phosphoniumhexafluorophosphate (BOP) $(1.7 \mathrm{~g}, 3.8 \mathrm{mmol})$, triethylamine (2.3 $\mathrm{mL}, 17.2 \mathrm{mmol})$, and dimethylaminopyridine (126 mg, $1.0 \mathrm{mmol})$, and 4-pentenyl$(1 R, 2 R)$-pseudoephedrine $(851 \mathrm{mg}, 2.5 \mathrm{mmol})$. The reaction was allowed to proceed at ambient temperature for $16 \mathrm{~h}$. The deep purple reaction mixture was quenched by the addition of $10 \mathrm{~mL}$ of $2 \mathrm{~N}$ potassium hydroxide and water. The solution was extracted five times with hexanes:ethyl acetate (1:1). The combined organic layers were washed with twice with $2 \mathrm{~N} \mathrm{HCl}$, saturated sodium bicarbonate, and brine. The organic layer was then dried over magnesium sulfate and subsequently filtered over a short pad of silica gel. The residue left after removal of solvent in vacuo was purified by flash chromatography 
(silica gel, 4:1 ethyl acetate:hexanes) affording $\mathbf{2}$ and $\mathbf{3}$ in a combined yield of 67\%. The diastereomers were initially separated from unconsumed 4-pentenoyl- $(1 R, 2 R)$ pseudoephedrine by flash chromatography (1.5:1, hexanes:ethyl acetate). Subsequently, the diastereomers $\left(\mathrm{R}_{\mathrm{f}}=0.81 \& 0.75 ; 4: 1\right.$ ethyl acetate:methylene chloride) were separated from one another by flash chromatography (silica gel, 5:1 methylene chloride:ethyl acetate). 2 was the less polar of the two diastereomeric products.

Protocol B: Metathesis substrates 2 and 3. Racemic 4 (1.0 g, $2.0 \mathrm{mmol}$,) was dissolved in $60 \mathrm{~mL}$ of dry methylene chloride and stirred at room temperature. To this flask was added 1-[3-(Dimethylamino)propyl]-3-ethylcarbodiimide hydrochloride (EDC) (575 mg, $3.0 \mathrm{mmol}$ ) and 4-(Dimethylamino)-pyridine (DMAP) $(50 \mathrm{mg}, 0.40 \mathrm{mmol})$ which were stirred for $30 \mathrm{~min} . \quad N$-4-pentenoyl-( $(1 R, 2 R)$-pseudoephedrine $(760 \mathrm{mg}, 3.0 \mathrm{mmol})$ was dissolved in $10 \mathrm{~mL}$ of dry methylene chloride and then added slowly to the flask containing (+/-)-4, EDC and DMAP (complete addition took $20 \mathrm{~min}$ ). The reaction was monitored by TLC using a 2:1, methylene chloride:ethyl acetate mobile phase. Two product spots were visualized on the TLC plate using a Phosphomolybdic acid (PMA) stain. The $\mathrm{R}_{f}$ values of the newly formed diastereomers $\mathbf{2}$ and $\mathbf{3}$ were 0.47 and 0.40 respectively. Once all the starting material was consumed the mixture was concentrated under vacuum and loaded directly onto a silica gel column. Column chromatography was conducted using an isocratic 1:1, methylene chloride:ethyl acetate mobile phase and yielded compound $\mathbf{2}$ (47\%) and compound $\mathbf{3}(45 \%)$. 
Metathesis Substrate 2. Pale yellow oil, $\left(\mathrm{R}_{\mathrm{f}}=0.81,4: 1\right.$ ethyl acetate:methylene chloride). ${ }^{1} \mathrm{H} \mathrm{NMR}\left(\mathrm{CDCl}_{3}, 500 \mathrm{MHz}\right)$. See spectrum (mixture of rotamers). ${ }^{13} \mathrm{C} \mathrm{NMR}$ $\left(\mathrm{CDCl}_{3}, 100 \mathrm{MHz}\right) \delta 173.0,172.9,172.7,172.5,169.2,168.9,168.9,167.1,167.1,166.7$, 159.1, 159.0, 137.6, 137.6, 136.8, 136.8, 136.7, 135.7, 135.5, 135.4, 135.3, 135.2, 133.6, $133.6,133.4,132.0,131.9,131.2,129.4,129.2,129.2,129.1,129.0,129.0,128.9,128.9$, $128.6,128.5,128.4,128.0,128.0,127.4,127.3,127.3,127.2,127.2,127.1,126.5,126.5$, $119.8,119.7,117.8,115.5,115.1,114.1,91.6,91.7,80.2,80.1,80.0,76.3,76.2,59.0$ $58.8,55.6,55.2,55.2,50.8,50.7,50.6,49.5,49.2,48.8,48.4,47.0,46.7,44,9,33.4,33.2$, 29.4, 29.0, 26.8, 15.4, 14.7; HRMS (EI) calculated for $\mathrm{C}_{43} \mathrm{H}_{47} \mathrm{~N}_{3} \mathrm{O}_{7}[\mathrm{M}+\mathrm{H}]$ : 718.3493, found: 718.3492 .

Metathesis Substrate 3. Pale yellow oil, $\left(\mathrm{R}_{\mathrm{f}}=0.75,4: 1\right.$ ethyl acetate:methylene chloride). ${ }^{1} \mathrm{H} \mathrm{NMR}\left(\mathrm{CDCl}_{3}, 500 \mathrm{MHz}\right)$. See spectrum. ${ }^{13} \mathrm{C} \mathrm{NMR}\left(\mathrm{CDCl}_{3}, 100 \mathrm{MHz}\right)$ $\delta 173.6,173.0,173.0,172.9,169.3,169.3,167.7,166.0,166.7,159.2,159.1,137.7$, $137.7,137.6,137.5,137.3,137.2,136.7,135.3,135.0,134.9,134.4,134.0,133.3,131.2$, $129.6,129.5,129.4,129.3,129.2,129.0,128.9,128.9,128.8,128.8,128.8,128.7,128.6$ $128.6,128.1,128.0,128.0,127.8,127.5,127.5,127.4,127.3,127.3,127.2,127.2,127.0$, $127.0,126.5,119.7,117.7,115.1,114.2,114.1,114.0,91.8,91.7,91.6,91.3,80.0,77.4$ $76.7,63.7,63.1,59.0,58.9,55.6,55.3,55.2,55.2,51.1,50.6,50.5,50.3,49.3,49.1,48.7$, 48.3, 47.0, 46.6, 45.7, 44.9, 43.8, 33.2, 33.1, 32.9, 29.4, 29.0, 15.1, 14.3; HRMS (EI) calculated for $\mathrm{C}_{43} \mathrm{H}_{47} \mathrm{~N}_{3} \mathrm{O}_{7}[\mathrm{M}+\mathrm{H}]$ : 718.3493, found: 718.3495. 


\section{Typical Procedure for Metathesis Reactions}

12-5-5-7 fused ring macrocyle 5. To a solution of 2 ( $84 \mathrm{mg}, 0.12 \mathrm{mmol})$ in $\mathrm{CH}_{2} \mathrm{Cl}_{2}(250$

$\mathrm{mL}$ ) was added the ruthenium based olefin metathesis catalyst containing 1,3-dimesityl-4, 5-dihydroimidazol-2-ylidene (10 $\mathrm{mg}, 0.012 \mathrm{mmol})$. The catalyst was added portion-wise (5 mol \% catalyst every $6 \mathrm{~h}$ ) until reaction was complete. The reaction mixture was stirred at $40{ }^{\circ} \mathrm{C}$ for $12 \mathrm{~h}$. TLC analysis indicated that the reaction was complete. After quenching the reaction with ethyl vinyl ether and removal of the solvent, the residue was purified by flash chromatography (silica gel, 2:1 ethyl acetate:hexanes) to afford $\mathbf{5}$ (65\%) as a brown solid $\left(\mathrm{R}_{\mathrm{f}}=0.47\right.$ ethyl acetate $) .{ }^{1} \mathrm{H} \mathrm{NMR}\left(\mathrm{CDCl}_{3}, 600 \mathrm{MHz}\right)$ See spectral data for complete assignment. $\delta$ 7.39-7.36 (m, 5H), 7.33-7.27 (m, 3H), $7.19(\mathrm{~d}, J=6.6 \mathrm{~Hz}$, 2H), $7.14(\mathrm{~d}, J=8.4 \mathrm{~Hz}, 2 \mathrm{H}), 6.87(\mathrm{~d}, J=8.4 \mathrm{~Hz}, 2 \mathrm{H}), 6.40(\mathrm{td}, J=11.0,39.0 \mathrm{~Hz}, 1 \mathrm{H})$, $5.90(\mathrm{t}, J=4.8 \mathrm{~Hz}, 1 \mathrm{H}), 5.85(\mathrm{~m}, 2 \mathrm{H}), 5.65(\mathrm{~d}, J=10.8 \mathrm{~Hz}, 1 \mathrm{H}), 5.45(\mathrm{~m}, 1 \mathrm{H}), 5.25(\mathrm{~d}, J$ $=14.4 \mathrm{~Hz}, 1 \mathrm{H}), 5.13(\mathrm{dd}, J=9.0,15.6 \mathrm{~Hz}, 1 \mathrm{H}), 4.60(\mathrm{~d}, J=15.0 \mathrm{~Hz}, 1 \mathrm{H}), 4.56(\mathrm{~s}, 1 \mathrm{H})$, $4.52(\mathrm{~d}, J=14.4 \mathrm{~Hz}, 1 \mathrm{H}), 4.43(\mathrm{t}, J=7.2 \mathrm{~Hz}, 1 \mathrm{H}), 4.05(\mathrm{~d}, J=15.6 \mathrm{~Hz}, 1 \mathrm{H}), 3.99(\mathrm{~d}, J=$ $14.4 \mathrm{~Hz}, 1 \mathrm{H}), 3.81(\mathrm{~s}, 3 \mathrm{H}), 3.62(\mathrm{~d}, J=6.6 \mathrm{~Hz}, 1 \mathrm{H}), 3.25-3.16(\mathrm{~m}, 1 \mathrm{H}), 2.98(\mathrm{~s}, 3 \mathrm{H})$, 2.84-2.80 (m, 1H), 2.77-2.73 (m, 1H), 2.35-2.19 (m, 2H), $0.83(\mathrm{~d}, J=6.6 \mathrm{~Hz}, 3 \mathrm{H}) ;{ }^{13} \mathrm{C}$ NMR $\left(\mathrm{CDCl}_{3}, 100 \mathrm{MHz}\right) \delta 172.8,171.7,170.8,168.1,159.2,136.9,136.5,134.1,133.6$, $133.1,132.9,130.1,129.9,129.7,129.5,129.3,129.0,128.9,128.7,128.5,128.4,127.9$, $127.8,127.5,127.3,125.1,114.2,84.0,82.8,82.4,81.9,78.4,69.0,67.5,64.5,55.3,55.0$, 54.6, 54.2, 53.5, 51.2, 53.5, 51.1, 50.0, 45.8, 45.6, 42.0, 41.1, 32.6, 30.4, 29.5, 29.0, 27.1, 14.6, 14.0; HRMS (EI) calculated for $\mathrm{C}_{41} \mathrm{H}_{43} \mathrm{~N}_{3} \mathrm{O}_{7}[\mathrm{M}+\mathrm{H}]:$ : 690.3179, found: 690.3167 . 
The structure of the fused ring product was proposed based on spectroscopic analogy to a previously described 7-5-5-7 fused ring product of related structure (Lee, D.; Sello, J. K.; Schreiber, S. L. Org. Lett, 2000, 2, 709- 712). The spectra of both molecules share characeteristic olefinic protons signals. In particular. the spectra of these molecules have a characteristic doublet at 6.4 or 6.24 ppm that can be assigned as the olefinic hydrogen atom of the seven membered ring that is adjacent to the cycloadduct's quaternary center. In both cases, the doublet has a coupling constant of $10.7 \mathrm{~Hz}$ that is consistent with the proposed cis geometry of the olefin in the fused seven membered ring. Furthermore, both spectra share a multiplet at 5.8 ppm that can be assigned as the other three olefinic protons of the molecule. The proposed 12-5-5-7 fused structure was further validated by a series of 1D TOCSY NMR experiments. Moreover, the molecular mass of this molecule is consistent with the proposed fused ring structure. The structures of all other 12-5-5-7 fused ring compounds(10,14,18 and 22) were inferred by analogy to the NMR spectra of this molecule and by molecular mass.

Bridged macrocycle 6. To a solution of $3(80 \mathrm{mg}, 0.11 \mathrm{mmol})$ in $\mathrm{CH}_{2} \mathrm{Cl}_{2}(250 \mathrm{~mL})$ was added the ruthenium based olefin metathesis catalyst containing 1,3-dimesityl-4, 5dihydroimidazol-2-ylidene $(9 \mathrm{mg}, 0.01 \mathrm{mmol})$. The catalyst was added portion-wise (5 mol \% catalyst every $6 \mathrm{~h}$ ) until reaction was complete. The reaction mixture was stirred at $40{ }^{\circ} \mathrm{C}$ for $16 \mathrm{~h}$. After quenching the reaction with ethyl vinyl ether and removal of the solvent, the residue was purified by flash chromatography (silica gel, 2:1 ethyl acetate: hexanes) to afford $6(87 \%)$ as a brown solid with an $E / Z$ ratio of $10: 1 . \quad\left(\mathrm{R}_{\mathrm{f}}=0.83\right.$ ethyl acetate). The product was recrystallized from ethyl acetate:methylene chloride:hexanes 
2:1:2 mixture. ${ }^{1} \mathrm{H}$ NMR $\left(\mathrm{CDCl}_{3}, 600 \mathrm{MHz}\right)$. Data refers to the $Z$ isomer. $\delta 7.45(\mathrm{~d}, J=$ $7.2 \mathrm{~Hz}, 2 \mathrm{H}), 7.39-7.34(\mathrm{~m}, 3 \mathrm{H}), 7.30(\mathrm{t}, J=1.8 \mathrm{~Hz}, 3 \mathrm{H}), 7.00(\mathrm{~d}, J=8.4 \mathrm{~Hz}, 2 \mathrm{H}), 6.94(\mathrm{t}$, $J=3.6 \mathrm{~Hz}, 2 \mathrm{H}), 6.73(\mathrm{~d}, J=9.0 \mathrm{~Hz}, 2 \mathrm{H}), 6.53(\mathrm{~d}, J=4.8 \mathrm{~Hz}, 1 \mathrm{H}), 6.27(\mathrm{~d}, J=6.0 \mathrm{~Hz}$, $1 \mathrm{H}), 5.81-5.73(\mathrm{~m}, 2 \mathrm{H}), 5.62(\mathrm{~d}, J=10.8 \mathrm{~Hz}, 1 \mathrm{H}), 5.43-5.40(\mathrm{dd}, J=6.0,14.4 \mathrm{~Hz}, 1 \mathrm{H})$, 5.31-5.27 (m, 1H), $5.25(\mathrm{~d}, J=3.0 \mathrm{~Hz}, 1 \mathrm{H}), 5.21(\mathrm{~d}, J=15.6 \mathrm{~Hz}, 1 \mathrm{H}), 4.55(\mathrm{~s}, 1 \mathrm{H}), 5.53$ $(\mathrm{d}, J=16.8 \mathrm{~Hz}, 1 \mathrm{H}), 4.21(\mathrm{~d}, J=16.8 \mathrm{~Hz}, 1 \mathrm{H}), 3.81(\mathrm{~d}, J=15.0 \mathrm{~Hz}, 1 \mathrm{H}), 3.72(\mathrm{~s}, 3 \mathrm{H})$, $3.50(\mathrm{t}, J=3.6 \mathrm{~Hz}, 1 \mathrm{H}), 3.04(\mathrm{~d}, J=3.0 \mathrm{~Hz}, 1 \mathrm{H}), 3.00(\mathrm{dd}, J=6.6,7.2 \mathrm{~Hz}, 1 \mathrm{H}), 2.94(\mathrm{q}, J$ $=13.2 \mathrm{~Hz}, 1 \mathrm{H}), 2.73(\mathrm{~s}, 3 \mathrm{H}), 2.54-2.48(\mathrm{ddt}, J=4.8,5.4,16.8 \mathrm{~Hz}, 1 \mathrm{H}), 2.35-2.31(\mathrm{~m}$, $1 \mathrm{H}), 2.03(\mathrm{t}, J=13.8 \mathrm{~Hz}, 1 \mathrm{H}), 0.83(\mathrm{~d}, J=7.2 \mathrm{~Hz}, 3 \mathrm{H}) ;{ }^{13} \mathrm{C} \mathrm{NMR}\left(\mathrm{CDCl}_{3}, 100 \mathrm{MHz}\right) \delta$ $173.4,171.5,170.0,165.6,159.2,138.1,138.0,137.0,135.2,133.4,129.7,129.3,129.1$, $129.1,128.4,128.2,127.7,126.8,123.5,114.3,91.6,80.2,77.4,76.5,59.0,55.4,50.8$, $49.9,48.9,47.7,45.1,39.0,33.7,32.2,29.9,29.6,28.6,23.9,22.9,14.6$; HRMS (EI) calculated for $\mathrm{C}_{41} \mathrm{H}_{43} \mathrm{~N}_{3} \mathrm{O}_{7}[\mathrm{M}+\mathrm{H}]$ : 690.3179, found: 690.3176 .

Crystallographic data: orthorhombic single crystal $\left(0.25 \times 0.1 \times 0.05 \mathrm{~mm}^{3}\right.$, Space group $\mathrm{P} 22_{1} 22_{1}$, Unit cell constants $a=8.260(1), b=16.714(3), c=26.608(6) \AA, \alpha=90^{\circ}, \beta=$ $\left.90^{\circ}, \gamma=90^{\circ}, V=3674(1) \AA^{3}, Z=4, D_{x}=1.251 \mathrm{~g} / \mathrm{cm}^{3}\right)$. X-ray diffraction data were collected using a Bruker SMART CCD diffractometer equipped with an LT-2 lowtemperature apparatus at $213 \mathrm{~K}$. Data were measured using omega scans of $0.3^{\circ}$ per frame for 30 seconds. A total of 1271 frames were collected with a maximum resolution of $0.80 \AA$. Cell parameters were retrieved using SMART software and refined using SAINT on all observed reflections. Data reduction was performed with SAINT and the structures are solved by the direct method using the SHELXS-97 program incorporated in 
SHELXTL-PC V 5.10 and refined by least squares method on $\mathrm{F}^{2}$. The final agreement factors are $R(F)=0.0534, R \mathrm{w}(F)=0.1121$.

The proposed structure of the bridged ring product was confirmed by $x$-ray crystallography. The structures of all other reported bridged rings $(8,12,16$, and 20$)$ were confirmed by $x$-ray crystallography or inferred by analogy to the proton NMR spectrum of this molecule.

Allyl carboxylate (+)-4. To a solution of $2(1.0 \mathrm{~g}, 1.4 \mathrm{mmol})$ in $15 \mathrm{~mL}$ of $\mathrm{MeOH}$ was added barium hydroxide-octahydrate $(879 \mathrm{mg}, 2.8 \mathrm{mmol})$. The reaction was stirred at ambient temperature for $12 \mathrm{~h}$. The reaction was quenched by the addition of $2 \mathrm{~N} \mathrm{HCl}$. The $\mathrm{pH}$ of the reaction mixture was brought to 2 by the slow addition of hydrochloric acid. A small volume of methanol was added to this mixture to clarify the solution. The aqueous reaction mixture was extracted five times with methylene chloride. The combined organic layers were washed with brine. The resultant organic layer was dried with magnesium sulfate and filtered through a short pad of silica gel. After removal of the solvent in vacuo, the residue was purified by silica gel chromatography $(3: 1$ ethyl acetate: hexanes to 9:1 ethyl acetate:methanol) yielding (+)-4 in 90\%. $[\alpha]^{20}{ }_{D}=+0.63^{0}$ (c $\left.=1.0, \mathrm{CHCl}_{3}\right) .{ }^{1} \mathrm{H} \mathrm{NMR}\left(\mathrm{CDCl}_{3}, 500 \mathrm{MHz}\right)$. See spectrum. ${ }^{13} \mathrm{C} \mathrm{NMR}\left(\mathrm{CDCl}_{3}, 100\right.$ MHz) $\delta 175.2,166.6,166.3,159.2,159.1,136.64,135.7,135.1,132.8,131.9,131.1$, $129.5,129.3,129.0,128.9,128.91,128.8,128.6,128.1,128.0,127.9,126.7,126.5,120.0$ $117.8,114.2,114.1,91.7,80.5,80.4,59.5,59.4,55.3,55.2,51.3,49.4,49.2,48.9,48.3$, 
46.4, 45.2. The absolute stereochemistry of (+)-4 could be inferred from the X-ray crystal information obtained on $\mathbf{8}$, which was prepared from (+)-4.

Allyl carboxylate (-)-4. To a solution of $\mathbf{3}(676 \mathrm{mg}, 0.94 \mathrm{mmol})$ in $15 \mathrm{~mL}$ of $\mathrm{MeOH}$ was added barium hydroxide-octahydrate $(594 \mathrm{mg}, 1.88 \mathrm{mmol})$. The reaction was stirred at ambient temperature for $12 \mathrm{~h}$. The reaction was quenched by the addition of $2 \mathrm{~N} \mathrm{HCl}$. The $\mathrm{pH}$ of the reaction mixture was brought to 2 by the slow addition of hydrochloric acid. A small volume of methanol was added to this mixture to clarify the solution. The aqueous reaction mixture was extracted five times with methylene chloride. The combined organic layers were washed with brine. The resultant organic layer was dried with magnesium sulfate and filtered through a short pad of silica gel. After removal of the solvent in vacuo, the residue was purified by flash chromatography (silica gel, 3:1 ethyl acetate:hexanes to 9:1 ethyl acetate:methanol) yielding (-)-4 in 93\%. $[\alpha]_{\mathrm{D}}^{20}=-$ $0.440^{\circ}\left(\mathrm{c}=1.0, \mathrm{CHCl}_{3}\right) .{ }^{1} \mathrm{H} \mathrm{NMR}\left(\mathrm{CDCl}_{3}, 500 \mathrm{MHz}\right)$. See spectrum. ${ }^{13} \mathrm{C} \mathrm{NMR}\left(\mathrm{CDCl}_{3}\right.$, $100 \mathrm{MHz}) \delta 178.2,166.6,166.3,159.2,159.0,136.7,135.7,135.1,133.0,131.9,129.8$, $129.5,129.3,129.0,129.0,128.9,129.0,128.6,128.1,128.0,127.9,126.7,126.5,119.7$, $117.8,114.2,113.2,91.7,80.5,80.2,59.5,59.4,55.6,55.2,51.1,49.5,49.2,48.9,48.1$, 46.7, 44.8. The absolute stereochemistry of (-)-4 could be inferred from the X-ray crystal information obtained on 6, which was prepared from (-)-4.

The resolved acids, (+)-4 and (-)-4, were used to prepare all reaction substrates. All metathesis reaction substrates were synthesized using conditions identical to those described for the preparation of 2 and 3 . Substrates $7,11,15$, and 19 were prepared from (+)-4. Substrates 9, 13, 17, and 21 were prepared from (-)-4. Metathesis reactions were 
carried out as described above, at $0.0005 \mathrm{M}$ and catalyzed by the ruthenium based olefin metathesis catalyst containing 1,3-dimesityl-4,5-dihydroimidazol-2-ylidene.

Metathesis substrate 7. Yield: $54 \%$. Pale yellow oil. ${ }^{1} \mathrm{H} \mathrm{NMR}\left(\mathrm{CDCl}_{3}, 500 \mathrm{MHz}\right)$. See spectrum. ${ }^{13} \mathrm{C}$ NMR $\left(\mathrm{CDCl}_{3}, 100 \mathrm{MHz}\right) \delta 173.1,172.1,169.6,167.1,166.8,159.2$, $137.0,136.9,136.8,135.8,135.7,135.2,133.5,133.4,132.0,131.2,129.4,129.2,129.0$, $128.9,128.86,128.7,128.6,128.1,128.0,127.2,127.1,126.9,126.87,126.6,119.8$, $117.9,115.7,114.1,114.1,91.5,91.5,80.0,79.9,75.7,71.6,59.0,59.0,55.3,55.2,52.9$, 51.0, 49.5, 49.2, 48.8, 48.5; 47.0, 45.0, 35.8, 29.5; Low Res. EIMS [M+H] calculated for $\mathrm{C}_{43} \mathrm{H}_{47} \mathrm{~N}_{3} \mathrm{O}_{8}:$ : 734.3, found: 734.3.

Bridged Macrocycle 8. Catalyst loading: $10 \mathrm{~mol} \%$. Reaction time: $12 \mathrm{~h}$. Yield: $52 \%$ $\left(R_{f}=0.79\right.$ ethyl acetate $)$. The product was recrystallized from ethyl acetate-methylene chloride. ${ }^{1} \mathrm{H}$ NMR $\left(\mathrm{CDCl}_{3}, 500 \mathrm{MHz}\right)$. See spectrum. ${ }^{13} \mathrm{C} \mathrm{NMR}\left(\mathrm{CDCl}_{3}, 100 \mathrm{MHz}\right) \delta$ $173.2,171.2,169.8,166.3,158.9,139.2,137.0,136.6,135.4,133.1,129.6,129.5,129.0$ $129.0,128.8,128.7,128.4,128.0,127.7,127.5,127.2,126.5,124.2,114.0,94.2,91.4$ $80.2,75.8,70.8,58.9,58.7,55.2,55.1,53.3,50.6,49.7,47.4,45.9,44.9,35.2,29.6,26.8$. HRMS (EI) calculated for $\mathrm{C}_{41} \mathrm{H}_{43} \mathrm{~N}_{3} \mathrm{O}_{8}[\mathrm{M}+\mathrm{H}]:$ : 706.3128, found: 706.3150 .

Crystallographic data: orthorhombic single crystal $\left(0.10 \times 0.12 \times 0.12 \mathrm{~mm}^{3}\right.$, Space group $\mathrm{P} 22_{1} 2_{1}{ }_{1}$, Unit cell constants $a=9.4799(5), b=17.1466(9), c=23.3272(13) \AA, \alpha=90^{\circ}, \beta$ $\left.=90^{\circ}, \gamma=90^{\circ}, V=3791.8(4) \AA^{3}, Z=4, D x=1.236 \mathrm{~g} / \mathrm{cm}^{3}\right)$. X-ray diffraction data were collected using a Bruker SMART CCD diffractometer equipped with an LT-2 lowtemperature apparatus at $213 \mathrm{~K}$. Data were measured using omega scans of $0.3^{\circ}$ per frame for 30 seconds. A total of 1271 frames were collected with a maximum resolution 
of $0.75 \AA$. Cell parameters were retrieved using SMART software and refined using SAINT on all observed reflections. Data reduction was performed with SAINT and the structures are solved by the direct method using the SHELXS-97 program incorporated in SHELXTL-PC V 5.10 and refined by least squares method on $\mathrm{F}^{2}$. The final agreement factors are $R(F)=0.0718, R \mathrm{w}(F)=0.1741$.

Metathesis substrate 9. Yield: $54 \%$. Pale yellow oil. ${ }^{1} \mathrm{H}$ NMR $\left(\mathrm{CDCl}_{3}, 500 \mathrm{MHz}\right)$. See spectrum. ${ }^{13} \mathrm{C}$ NMR $\left(\mathrm{CDCl}_{3}, 100 \mathrm{MHz}\right) \delta 137.1,172.1,169.6,167.1,166.8,159.2$, 137.0, 136.9, 136.8, 135.8, 135.7, 135.2, 133.5, 133.4, 132.0, 131.2, 129.4, 129.2, 129.0, $128.9,128.9,128.7,128.6,128.1,128.0,127.2,127.1,126.9,126.6,119.8,117.9,115.7$, $114.1,114.1,91.5,91.5,80.0,79.9,75.7,71.6,59.0,59.0,55.3,55.2,52.9,51.0,49.5$, 49.2, 48.8, 48.5; 47.0, 45.0, 35.8, 29.5; Low Res. EIMS [M+H] calculated for $\mathrm{C}_{43} \mathrm{H}_{47} \mathrm{~N}_{3} \mathrm{O}_{8}:$ : 734.3, found: 734.3 .

12-5-5-7 fused macrocycle 10. Catalyst loading: $10 \mathrm{~mol} \%$, reaction time: $16 \mathrm{~h}$, yield: $56 \%\left(\mathrm{R}_{\mathrm{f}}=0.34\right.$ ethyl acetate $) .{ }^{1} \mathrm{H}$ NMR $\left(\mathrm{CDCl}_{3}, 500 \mathrm{MHz}\right)$. See spectrum. ${ }^{13} \mathrm{C}$ NMR $\left(\mathrm{CDCl}_{3}, 100 \mathrm{MHz}\right) \delta 171.6,171.3,171.1,168.1,159.2,136.8,136.5,133.6,132.4,130.0$, $129.9,128.9,128.8,128.6,128.4,127.7,127.7,127.6,126.3,114.2,82.8,81.5,71.1$, 69.0, 59.0, 55.2, 55.1, 54.2, 52.1, 51.1, 45.7, 41.9, 34.8, 27.1; HRMS (EI) calculated for $\mathrm{C}_{41} \mathrm{H}_{43} \mathrm{~N}_{3} \mathrm{O}_{8}[\mathrm{M}+\mathrm{H}]:$ 706.3128, found: 706.3108 .

Metathesis substrate 11. Yield: $63 \%$. Pale yellow oil. ${ }^{1} \mathrm{H}$ NMR $\left(\mathrm{CDCl}_{3}, 500 \mathrm{MHz}\right)$. See spectrum. ${ }^{13} \mathrm{C} \mathrm{NMR}\left(\mathrm{CDCl}_{3}, 100 \mathrm{MHz}\right) \delta 173.4,173.4,171.9,169.5,166.9,166.5$, 
159.1, 159.0, 137.0, 137.0, 136.9, 136.6, 135.2, 135.1, 133.3, 133.3, 131.8, 131.1, 129.3, $129.1,128.9,128.8,128.7,128.4,128.1,128.0,128.0,127.0,126.9,126.4,126.3,126.2$, $119.8,117.7,115.5,114.1,114.0,91.6,91.5,80.1,80.1,78.3,59.1,58.9,55.2,55.1,51.3$, 51.2, 49.4, 49.1, 48.8, 48.5, 48.4, 48.3, 46.5, 44.9, 35.5, 29.4, 14.8, 14.6; Low Res. EIMS $[\mathrm{M}+\mathrm{H}]$ calculated for $\mathrm{C}_{42} \mathrm{H}_{45} \mathrm{~N}_{3} \mathrm{O}_{7}:$ 704.3, found: 704.3.

Bridged Macrocycle 12. Catalyst loading: $15 \mathrm{~mol} \%$, reaction time: $16 \mathrm{~h}$, yield: $66 \%\left(\mathrm{R}_{\mathrm{f}}\right.$ $=0.80$ ethyl acetate). The product was recrystallized from methylene chloride- ethyl acetate. ${ }^{1} \mathrm{H} \mathrm{NMR}\left(\mathrm{CDCl}_{3}, 500 \mathrm{MHz}\right)$. See spectrum. ${ }^{13} \mathrm{C} \mathrm{NMR}\left(\mathrm{CDCl}_{3}, 100 \mathrm{MHz}\right)$ $\delta 173.1,170.6,168.5,166.2,159.0,136.7,135.4,134.8,133.9,133.7,129.6,129.0$, $128.8,128.0,127.5,127.3,126.5,122.7,114.1,91.9,81.1,76.2,59.1,55.2,50.9,49.2$ 48.0, 47.5, 47.3, 45.0, 33.8, 25.8, 18.8; HRMS (EI) calculated for $\mathrm{C}_{40} \mathrm{H}_{41} \mathrm{~N}_{3} \mathrm{O}_{7}[\mathrm{M}+\mathrm{H}]$ : 676.3023, found: 676.3052 .

Crystallographic data: orthorhombic single crystal $\left(0.20 \times 0.10 \times 0.10 \mathrm{~mm}^{3}\right.$, Space group $\mathrm{P} 22_{1} 2_{1}$, Unit cell constants $a=13.6681(18), b=14.992(2), c=17.274(2) \AA, \alpha=90^{\circ}, \beta$ $\left.=90^{\circ}, \gamma=90^{\circ}, V=3539.6(8) \AA^{3}, Z=4, D x=1.268 \mathrm{~g} / \mathrm{cm}^{3}\right)$. X-ray diffraction data were collected using a Bruker SMART CCD diffractometer equipped with an LT-2 lowtemperature apparatus at $213 \mathrm{~K}$. Data were measured using omega scans of $0.3^{\circ}$ per frame for 30 seconds. A total of 1271 frames were collected with a maximum resolution of $0.75 \AA$. Cell parameters were retrieved using SMART software and refined using SAINT on all observed reflections. Data reduction was performed with SAINT and the structures are solved by the direct method using the SHELXS-97 program incorporated in 
SHELXTL-PC V 5.10 and refined by least squares method on $\mathrm{F}^{2}$. The final agreement factors are $R(F)=0.0630, R \mathrm{w}(F)=0.1433$.

Metathesis substrate 13. Yield: $60 \%$, pale yellow oil. ${ }^{1} \mathrm{H} \mathrm{NMR}\left(\mathrm{CDCl}_{3}, 500 \mathrm{MHz}\right)$. See spectrum. ${ }^{13} \mathrm{C} \mathrm{NMR}\left(\mathrm{CDCl}_{3}, 100 \mathrm{MHz}\right) \delta 173.2,171.7,169.4,167.0,166.7,159.1$, 159.0, 137.0, 136.7, 136.2, 136.1, 135.8, 135.8, 135.1, 133.10, 133.0, 131.9, 131.1, 129.4, $129.2,128.9,128.8,128.8,128.4,128.2,128.0,128.0,127.2,127.1,126.6,126.5,119.8$, $117.7,115.6,114.1,114.0,91.6,91.5,80.4,80.3,78.0,59.1,58.93,55.2,55.1,51.1,49.4$, 49.2, 48.7, 48.4, 47.8, 47.8, 46.8, 44.9, 35.8, 29.5, 15.8, 15.7; Low Res. EIMS [M+H] calculated for $\mathrm{C}_{42} \mathrm{H}_{45} \mathrm{~N}_{3} \mathrm{O}_{7}$ : 704.3, found: 704.3.

12-5-5-7 fused ring macrocycle 14. Catalyst loading: 15 mol \%, reaction time: $26 \mathrm{~h}$, yield: $46 \%\left(\mathrm{R}_{\mathrm{f}}=0.36\right.$ ethyl acetate $) .{ }^{1} \mathrm{H} \mathrm{NMR}\left(\mathrm{CDCl}_{3}, 500 \mathrm{MHz}\right)$. See spectrum. ${ }^{13} \mathrm{C}$ $\mathrm{NMR}\left(\mathrm{CDCl}_{3}, 100 \mathrm{MHz}\right) \delta 172.0,171.3,170.9,167.7,159.2,137.0,136.4,133.8,133.0$, $129.9,129.8,129.5,128.7,128.6,128.5,127.9,127.8,127.6,125.3,114.3,84.1,82.1$, 67.6, 55.3, 54.8, 53.6, 51.2, 49.4, 45.7, 42.0, 35.8, 29.2, 13.2; HRMS (EI) calculated for $\mathrm{C}_{40} \mathrm{H}_{41} \mathrm{~N}_{3} \mathrm{O}_{7}[\mathrm{M}+\mathrm{H}]:$ 676.3023, found: 676.3051 .

Metathesis substrate 15-Ph. Yield: 53\%. Pale yellow oil. ${ }^{1} \mathrm{H}$ NMR $\left(\mathrm{CDCl}_{3}, 500\right.$ $\mathrm{MHz})$. See spectrum. ${ }^{13} \mathrm{C} \mathrm{NMR}\left(\mathrm{CDCl}_{3}, 100 \mathrm{MHz}\right) \delta 173.4,172.7,169.7,166.9,159.2$, $137.4,137.1,136.7,135.2,135.1,135.1,133.3,133.3,131.8,131.1,129.4,129.2,129.0$, $128.9,128.8,128.7,128.6,128.1,128.0,127.1,126.5,126.4,117.8,115.6,114.1,114.1$, $91.6,91.5,80.1,80.0,76.0,59.2,59.0,55.2,55.18,51.4,51.3,49.4,49.2,48.8,48.3$, 
46.6, 45.0, 44.0, 43.9, 35.5, 29.4; Low Res. EIMS [M+H] calculated for $\mathrm{C}_{42} \mathrm{H}_{43} \mathrm{~N}_{3} \mathrm{O}_{7}$ : 690.3, found: 690.3 .

Bridged Macrocycle 16-Ph. Catalyst loading: 15 mol \%. Reaction time: 18 h. Yield: $51 \%\left(\mathrm{R}_{\mathrm{f}}=0.63\right.$ ethyl acetate $) .{ }^{1} \mathrm{H}$ NMR $\left(\mathrm{CDCl}_{3}, 500 \mathrm{MHz}\right)$. See spectrum. ${ }^{13} \mathrm{C}$ NMR $\left(\mathrm{CDCl}_{3}, 100 \mathrm{MHz}\right) \delta 173.1,171.4,169.0,166.2,159.0,136.8,135.9,135.5,135.4,133.7$, $129.6,129.4,129.1,128.98,128.9,128.5,128.1,127.2,126.6,126.5,126.2,125.9,123.0$, $114.2,114.1,91.8,80.9,72.5,59.1,55.2,50.8,49.4,47.6,47.3,45.0,43.7,33.9,26.1$; HRMS (EI) calculated for $\mathrm{C}_{40} \mathrm{H}_{39} \mathrm{~N}_{3} \mathrm{O}_{7}[\mathrm{M}+\mathrm{H}]:$ 662.2866, found: 662.2833 .

Metathesis substrate 17-Ph. Yield: $60 \%$. Pale yellow oil. ${ }^{1} \mathrm{H}$ NMR $\left(\mathrm{CDCl}_{3}, 500\right.$ MHz). See spectrum. ${ }^{13} \mathrm{C}$ NMR $\left(\mathrm{CDCl}_{3}, 100 \mathrm{MHz}\right) \delta 173.2,172.5,169.6,167.1,159.2$, 159.1, 137.1, 137.1, 136.9, 136.8, 136.0, 133.3, 133.3, 131.9, 131.2, 129.4, 129.2, 129.0, $128.9,128.9,128.7,128.6,128.1,128.0,127.2,126.5,126.3,119.9,117.8,115.7,114.1$, 114.1, 91.6, 91.5, 80.3, 80.2, 75.4, 59.2, 59.0, 55.3, 55.2, 51.0, 49.5, 49.3, 48.8, 48.5, 46.9, 45.0, 44.0, 35.7, 29.4; Low Res. EIMS [M+H] calculated for $\mathrm{C}_{41} \mathrm{H}_{43} \mathrm{~N}_{3} \mathrm{O}_{7}$ : 690.3, found: 690.3 .

12-5-5-7 fused ring macrocycle 18-Ph. Catalyst loading: 15 mol \%, Reaction time: 18 h. Yield: $55 \%\left(\mathrm{R}_{\mathrm{f}}=0.32\right.$ ethyl acetate $) .{ }^{1} \mathrm{H} \mathrm{NMR}\left(\mathrm{CDCl}_{3}, 500 \mathrm{MHz}\right)$ See spectrum. ${ }^{13} \mathrm{C}$ NMR $\left(\mathrm{CDCl}_{3}, 100 \mathrm{MHz}\right) \delta 172.1,171.9,170.8,167.8,159.2,144.3,137.2,136.4,133.3$, $133.1,129.9,129.6,129.3,129.0,128.8,128.8,128.7,128.5,127.8,127.5,126.5,114.2$, 
$83.7,81.9,75.3,67.9,55.3,54.8,53.7,51.2,48.3,47.5,45.7,44.6,42.0,35.6,28.8$; HRMS (EI) calculated for $\mathrm{C}_{39} \mathrm{H}_{39} \mathrm{~N}_{3} \mathrm{O}_{7}[\mathrm{M}+\mathrm{H}]:$ 662.2866, found: 662.2871 .

Metathesis substrate 15-Me. Yield: 55\%. Pale yellow oil. ${ }^{1} \mathrm{H} \mathrm{NMR}\left(\mathrm{CDCl}_{3}, 500 \mathrm{MHz}\right)$ See spectrum. ${ }^{13} \mathrm{C}$ NMR $\left(\mathrm{CDCl}_{3}, 100 \mathrm{MHz}\right) \delta 173.3,172.7,170.1,167.0,166.7,159.2$, 159.0, 137.1, 136.7, 135.3, 135.2, 135.1, 133.5, 133.4, 131.9, 131.2, 129.4, 129.2, 129.0, $128.9,128.8,128.1,128.0,127.1,127.0,126.5,119.9,117.8,115.6,114.1,114.1,91.6$ $91.5,80.1,80.0,71.5,59.2,59.9,55.2,55.2,51.5,51.4,49.5,49.2,48.9,48.4,46.7,45.0$, 43.5, 35.6, 29.5, 17.5; Low Res. EIMS [M+H] calculated for $\mathrm{C}_{36} \mathrm{H}_{41} \mathrm{~N}_{3} \mathrm{O}_{7}: 628.3$, found: 628.2 .

Bridged Macrocycle 16-Me. Catalyst loading: 15 mol \%. Reaction time: 20 h. Yield: $52 \%\left(\mathrm{R}_{\mathrm{f}}=0.43\right.$ ethyl acetate $) .{ }^{1} \mathrm{H}$ NMR $\left(\mathrm{CDCl}_{3}, 500 \mathrm{MHz}\right)$. See spectrum. ${ }^{13} \mathrm{C}$ NMR $\left(\mathrm{CDCl}_{3}, 100 \mathrm{MHz}\right) \delta 173.3,173.2,171.5,169.5,166.2,158.9,136.9,136.1,135.4,133.4$, $129.5,129.4,129.0,128.1,127.2,126.5,123.4,114.0,91.7,80.8,68.4,58.9,58.7,55.2$, 51.7, 50.6, 49.3, 47.1, 44.9, 43.4, 34.4, 26.7, 17.0, 15.7; HRMS (EI) calculated for $\mathrm{C}_{34} \mathrm{H}_{37} \mathrm{~N}_{3} \mathrm{O}_{7}[\mathrm{M}+\mathrm{H}]: 600.2710$, found: 600.2686 .

Metathesis substrate 17-Me. Yield: 60\%. Pale yellow oil. ${ }^{1} \mathrm{H}$ NMR $\left(\mathrm{CDCl}_{3}, 500\right.$ MHz). See spectrum. ${ }^{13} \mathrm{C}$ NMR $\left(\mathrm{CDCl}_{3}, 100 \mathrm{MHz}\right) \delta 173.3,172.5,170.0,167.2,166.8$, 159.0, 137.0, 136.7, 135.8, 135.7, 135.1, 133.4, 131.9, 131.2, 129.5, 129.4, 129.2, 129.0, $128.9,128.1,128.04,127.9,127.1,127.0,126.5,119.9,117.9,115.7,114.2,114.1$, $114.08,91.5,91.5,80.2,80.1,71.2,59.2,59.0,55.2,55.19,51.0,49.5,49.3,48.8,48.5$, 
47.0, 45.0, 43.6, 35.7, 29.5, 17.5; Low Res. EIMS [M+H] calculated for $\mathrm{C}_{36} \mathrm{H}_{41} \mathrm{~N}_{3} \mathrm{O}_{7}$ : 628.3, found: 628.3 .

12-5-5-7 fused ring macrocycle 18-Me. Catalyst loading: 15 mol \%. Reaction time: 32 h. Yield: $48 \%\left(\mathrm{R}_{\mathrm{f}}=0.20\right.$ ethyl acetate). ${ }^{1} \mathrm{H}$ NMR $\left(\mathrm{CDCl}_{3}, 500 \mathrm{MHz}\right)$. See spectrum. ${ }^{13} \mathrm{C}$ NMR $\left(\mathrm{CDCl}_{3}, 100 \mathrm{MHz}\right) \delta 177.9,172.0,153.1,149.8,133.4,131.7,130.7,130.1,130.0$, $129.7,129.5,129.4,128.8,128.5,128.5,127.8,127.4,114.1,94.3,84.1,81.8,76.4,72.6$, 70.4, 66.9, 55.3, 53.9, 52.3, 51.1, 45.5, 42.0, 37.3, 29.7, 25.4, 19.7, 17.8, 17.5; HRMS (EI) calculated for $\mathrm{C}_{34} \mathrm{H}_{37} \mathrm{~N}_{3} \mathrm{O}_{7}[\mathrm{M}+\mathrm{H}]$ : 600.2710 , found: 600.2686 .

Metathesis substrate 19. To a solution of $(+)-4(115 \mathrm{mg}, 0.24 \mathrm{mmol})$ in $\mathrm{CH}_{2} \mathrm{Cl}_{2}$ were added 1-(3-dimethylaminopropyl)-3-ethylcarbodiimide (EDC) (52 mg, $0.3 \mathrm{mmol}$ ), triethylamine $(0.100 \mathrm{~mL}, 0.7 \mathrm{mmol})$, dimethylaminopyridine (DMAP) $(7 \mathrm{mg}, 0.06$ $\mathrm{mmol}$ ), and (S)-phenylgycinol (32 $\mathrm{mg}, 0.24 \mathrm{mmol})$. The reaction mixture was stirred at ambient temperature for $16 \mathrm{~h}$. The reaction mixture was quenched by the addition of $2 \mathrm{~N}$ potassium hydroxide and water. The solution was extracted five times with hexanes: ethyl acetate (1:1). The combined organic layers were washed with twice with $2 \mathrm{~N} \mathrm{HCl}$, saturated sodium bicarbonate, and brine. The organic layer was then dried over magnesium sulfate and subsequently filtered over a short pad of silica gel. The residue left after removal of solvent in vacuo was purified by flash chromatography (silica gel, 4:1 ethyl acetate:hexanes) affording the desired product in $75 \%$ yield.

The reaction product $(56 \mathrm{mg}, 0.09 \mathrm{mmol})$ was added to a solution containing 4-pentenoic acid (9 mg, $0.09 \mathrm{mmol}$ ), 1-(3-dimethylaminopropyl)-3-ethylcarbodiimide (EDC) (21 mg, 
$0.11 \mathrm{mmol})$, triethylamine (0.04 $\mathrm{mL}, 0.3 \mathrm{mmol})$, and dimethylaminopyridine (DMAP) (2.2 $\mathrm{mg}, 0.02 \mathrm{mmol}$ ) dissolved in methylene chloride. After removal of solvent in vacuo, the crude reaction mixture was applied directly to a silica gel column. The title compound was isolated (3:1 ethyl acetate:hexanes) in $80 \%$ yield as a pale yellow oil. ${ }^{1} \mathrm{H}$ NMR $\left(\mathrm{CDCl}_{3}, 500 \mathrm{MHz}\right) . \quad$ See spectrum. ${ }^{13} \mathrm{C} \mathrm{NMR}\left(\mathrm{CDCl}_{3}, 100 \mathrm{MHz}\right) \delta 173.9,172.9$, $169.8,169.7,167.0,166.7,159.2,159.0,138.2,136.7,136.7,136.6,135.2,132.2,131.9$, $131.2,129.4,129.2,129.0,128.9,128.8,128.1,128.0,127.1,127.0,127.0,126.7,126.5$, $119.9,117.7,115.5,114.1,91.1,91.1,80.4,80.3,66.0,59.6,59.5,55.2,55.2,53.2,53.1$, 52.5, 49.4, 49.2, 48.9, 48.3, 45.0, 33.2, 28.6; Low Res. EIMS [M+H] calculated for $\mathrm{C}_{41} \mathrm{H}_{43} \mathrm{~N}_{3} \mathrm{O}_{7}: 690.3$, found: 690.3.

Bridged Macrocycle 20. To a solution of $19(49 \mathrm{mg}, 0.07 \mathrm{mmol})$ in $\mathrm{CH}_{2} \mathrm{Cl}_{2}(150 \mathrm{~mL})$ was added the ruthenium based olefin metathesis catalyst containing 1,3-dimesityl-4, 5dihydroimidazol-2-ylidene (11 mg, $0.01 \mathrm{mmol})$. The catalyst was added portion-wise (5 mol \% catalyst every $6 \mathrm{~h}$ ) until reaction was complete. The reaction mixture was stirred at $40{ }^{\circ} \mathrm{C}$ for $12 \mathrm{~h}$. TLC analysis indicated that the reaction was complete. After quenching the reaction with ethyl vinyl ether and removal of the solvent, the residue was purified by flash chromatography (silica gel, 2:1 ethyl acetate:hexanes) to afford 20 $(63 \%)$ as a brown solid $\left(\mathrm{R}_{\mathrm{f}}=0.64\right.$, ethyl acetate $) .{ }^{1} \mathrm{H} \mathrm{NMR}\left(\mathrm{CDCl}_{3}, 500 \mathrm{MHz}\right)$. See spectrum. ${ }^{13} \mathrm{C}$ NMR $\left(\mathrm{CDCl}_{3}, 100 \mathrm{MHz}\right)$ 8173.6, 172.6, 170.6, 166.3, 159.0, 139.3, $137.9,137.0,136.5,135.5,131.6,130.2,129.8,129.6,129.2,129.0,128.9,128.7,128.4$, $128.4,128.1,127.8,127.5,127.2,126.9,126.5,124.2,114.2,114.1,91.0,81.0,80.6$, 76.7, 68.2, 66.0, 59.1, 55.9. 55.3, 55.2, 54.6, 53.9, 51.6, 51.5, 51.1, 50.8, 48.8, 46.5, 45.2, 
33.2, 28.9, 27.1; HRMS (EI) calculated for $\mathrm{C}_{39} \mathrm{H}_{39} \mathrm{~N}_{3} \mathrm{O}_{7}$ [M+H]: 662.2866, found: 662.2849 .

Metathesis substrate 21. To a solution of (-)-4 (115 mg, $0.2 \mathrm{mmol})$ in $\mathrm{CH}_{2} \mathrm{Cl}_{2}$ were added 1-(3-dimethylaminopropyl)-3-ethylcarbodiimide (EDC) (52 mg, $0.3 \mathrm{mmol}$ ), triethylamine $(0.100 \mathrm{~mL}, 0.7 \mathrm{mmol})$, dimethylaminopyridine (DMAP) (7 mg, 0.06 mmol), and (S)-phenylgycinol (32 $\mathrm{mg}, 0.2 \mathrm{mmol})$. The reaction mixture was stirred at ambient temperature for $16 \mathrm{~h}$. The reaction mixture was quenched by the addition of $2 \mathrm{~N}$ potassium hydroxide and water. The solution was extracted five times with hexanes: ethyl acetate (1:1). The combined organic layers were washed twice with $2 \mathrm{~N} \mathrm{HCl}$, saturated sodium bicarbonate, and brine. The organic layer was then dried over magnesium sulfate and subsequently filtered over a short pad of silica gel. The residue left after removal of solvent in vacuo was purified by flash chromatography (silica gel, 4:1 ethyl acetate:hexanes) affording the desired product in $68 \%$.

The reaction product $(56 \mathrm{mg}, 0.09 \mathrm{mmol})$ was added to a solution containing 4-pentenoic acid (9 mg, $0.08 \mathrm{mmol}$ ), 1-(3-dimethylaminopropyl)-3-ethylcarbodiimide (EDC) (18 mg, $0.1 \mathrm{mmol})$, triethylamine $(0.033 \mathrm{~mL}, 0.24 \mathrm{mmol})$, and dimethylaminopyridine (DMAP) ( $2 \mathrm{mg}, 0.02 \mathrm{mmol}$ ) dissolved in methylene chloride. After removal of solvent in vacuo, the crude reaction mixture was applied directly to a silica gel column. The title compound was isolated (3:1 ethyl acetate:hexanes) in $82 \%$ yield. ${ }^{1} \mathrm{H} \mathrm{NMR}\left(\mathrm{CDCl}_{3}, 500\right.$ MHz). See spectrum. ${ }^{13} \mathrm{C}$ NMR $\left(\mathrm{CDCl}_{3}, 100 \mathrm{MHz}\right) \delta 173.9,172.9,169.6,169.5,167.0$, 166.6, 159.2, 159.0, 137.8, 136.7, 136.6, 136.5, 135.2, 135.3, 132.2, 131.9, 131.1, 129.4, $129.2,129.0,128.9,128.9,128.9,128.1,127.9,127.9,127.1,127.0,126.5,124.5,120.9$, 
$117.7,115.6,114.2,114.2,91.2,91.1,80.5,80.4,66.3,59.7,59.5,55.2,55.1,53.3,53.2$, 52.3, 49.4, 49.2, 48.9, 48.3, 48.3, 48.2, 45.0, 33.3, 28.7; Low Res. EIMS [M+H] calculated for $\mathrm{C}_{41} \mathrm{H}_{43} \mathrm{~N}_{3} \mathrm{O}_{7}: 690.3$, found: 690.3 .

12-5-5-7 fused ring macrocycle 22. To a solution of 21 (37 mg, $0.06 \mathrm{mmol})$ in $\mathrm{CH}_{2} \mathrm{Cl}_{2}$ $(120 \mathrm{~mL})$ was added the ruthenium based olefin metathesis catalyst containing 1,3dimesityl-4, 5-dihydroimidazol-2-ylidene $(6.9 \mathrm{mg}, 0.02 \mathrm{mmol})$. The catalyst was added portion-wise $(5 \mathrm{~mol} \%$ catalyst every $6 \mathrm{~h}$ ) until reaction was complete. The reaction mixture was stirred at $40{ }^{\circ} \mathrm{C}$ for $22 \mathrm{~h}$. TLC analysis indicated that the reaction was complete. After quenching the reaction with ethyl vinyl ether and removal of the solvent, the residue was purified by flash chromatography (silica gel, 2:1 ethyl acetate:hexanes) to afford $22(76 \%)$ as a brown solid $\left(\mathrm{R}_{\mathrm{f}}=0.32\right.$ ethyl acetate). ${ }^{1} \mathrm{H}$ NMR $\left(\mathrm{CDCl}_{3}, 500 \mathrm{MHz}\right)$. See spectrum. ${ }^{13} \mathrm{C}$ NMR $\left(\mathrm{CDCl}_{3}, 100 \mathrm{MHz}\right) \delta 173.7,172.8,169.8,168.1,159.2,148.4$, $138.9,137.4,136.5,133.9,133.4,131.3,129.7,129.5,129.0,128.7,128.6,128.5,128.3$, $127.8,127.7,126.8,114.2,83.9,82.3,76.7,68.6,66.6,64.9,64.6,55.7,55.3,54.8,54.6$, 51.2, 47.3, 45.7, 42.1, 39.3, 33.6, 28.0; HRMS (EI) calculated for $\mathrm{C}_{39} \mathrm{H}_{39} \mathrm{~N}_{3} \mathrm{O}_{7}[\mathrm{M}+\mathrm{H}]$ : 662.2866, found: 662.2870 . 
$500 \mathrm{MHz}$ in $\mathrm{CDCl}_{3}$

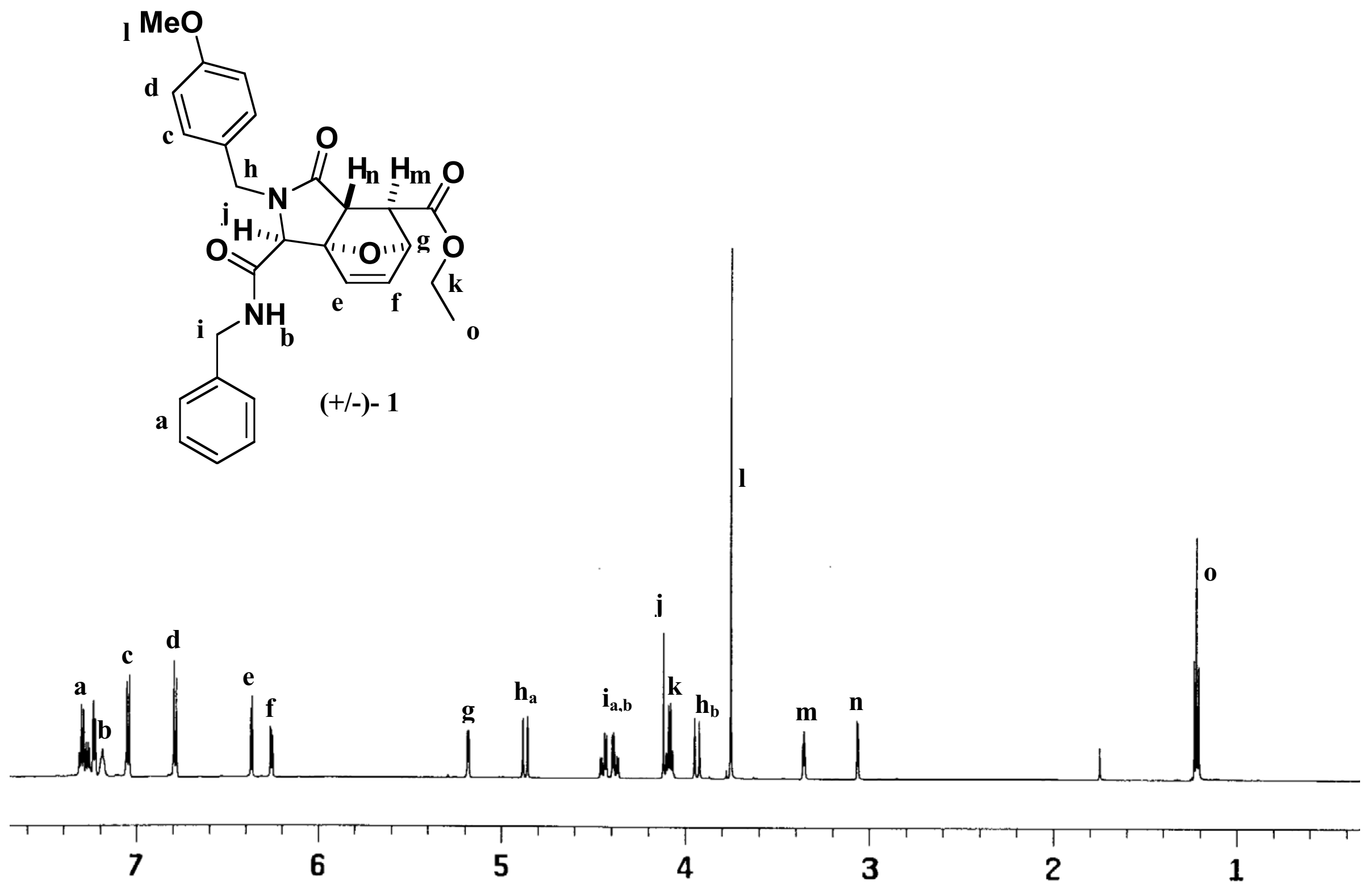


$500 \mathrm{MHz}-\mathrm{gCOSY} \mathrm{CDCl}_{3}$

$\mathrm{MeO}$
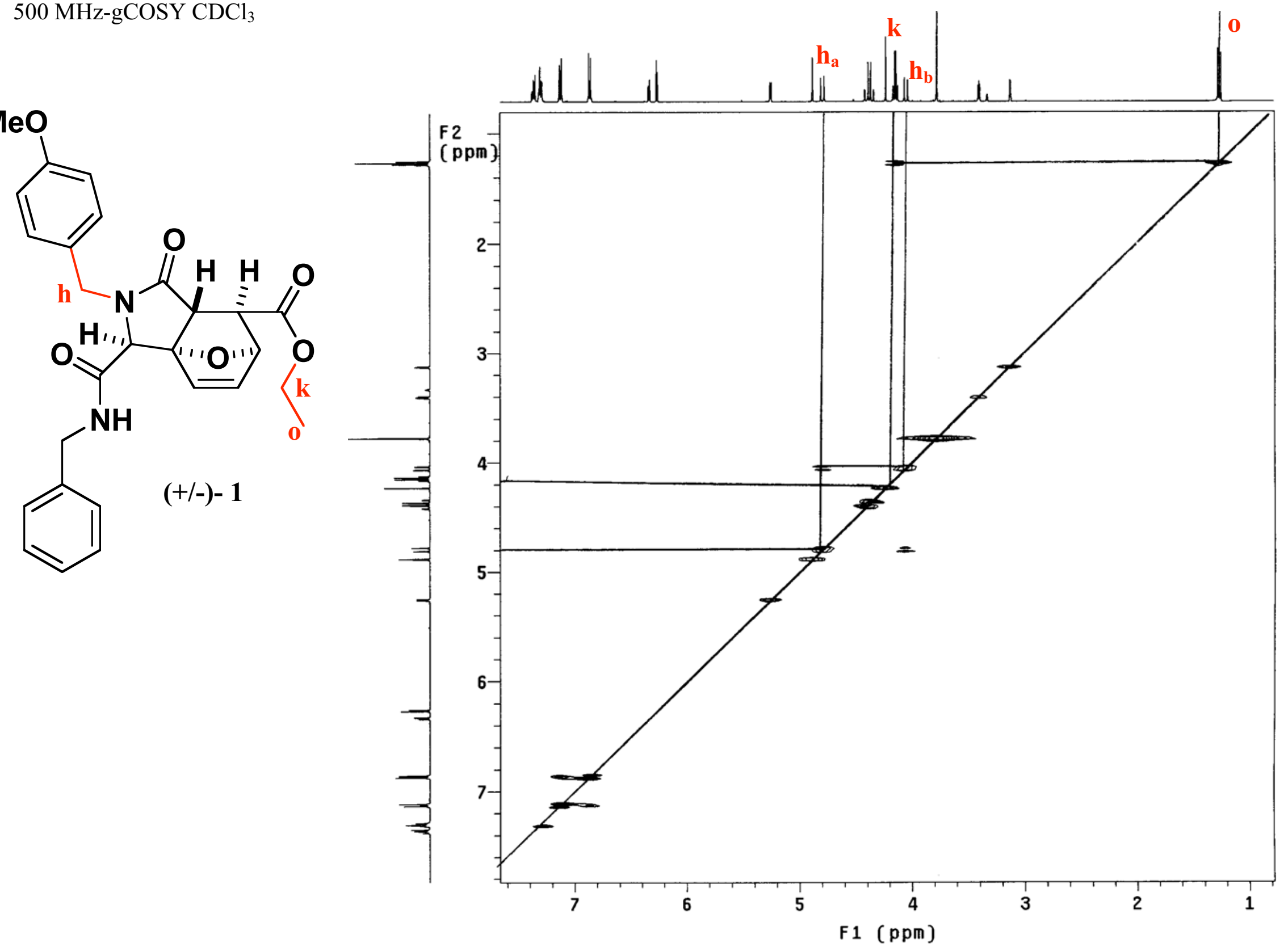
$500 \mathrm{MHz}-\mathrm{gCOSY} \mathrm{CDCl}_{3}$

$\mathrm{MeO}$

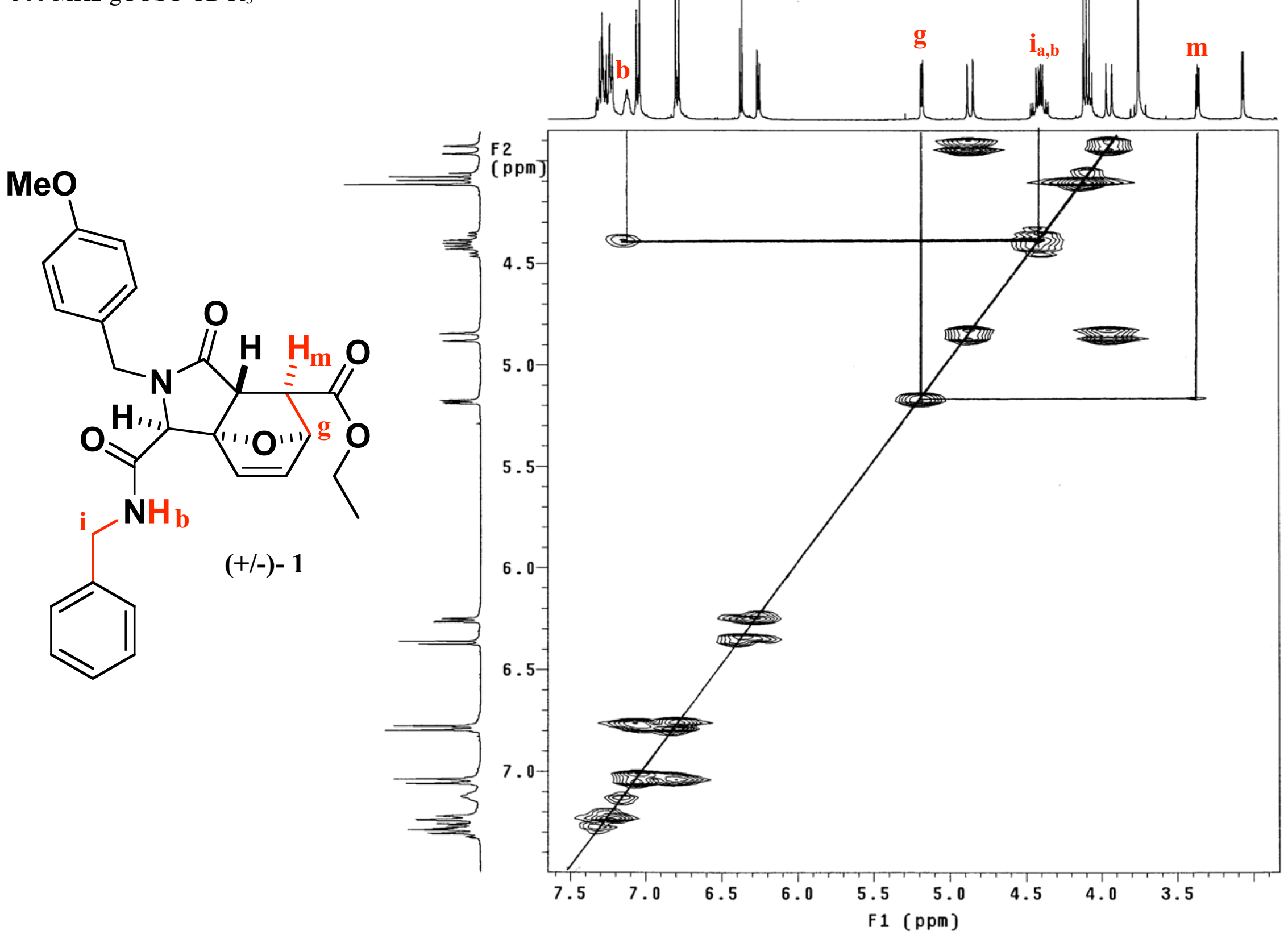




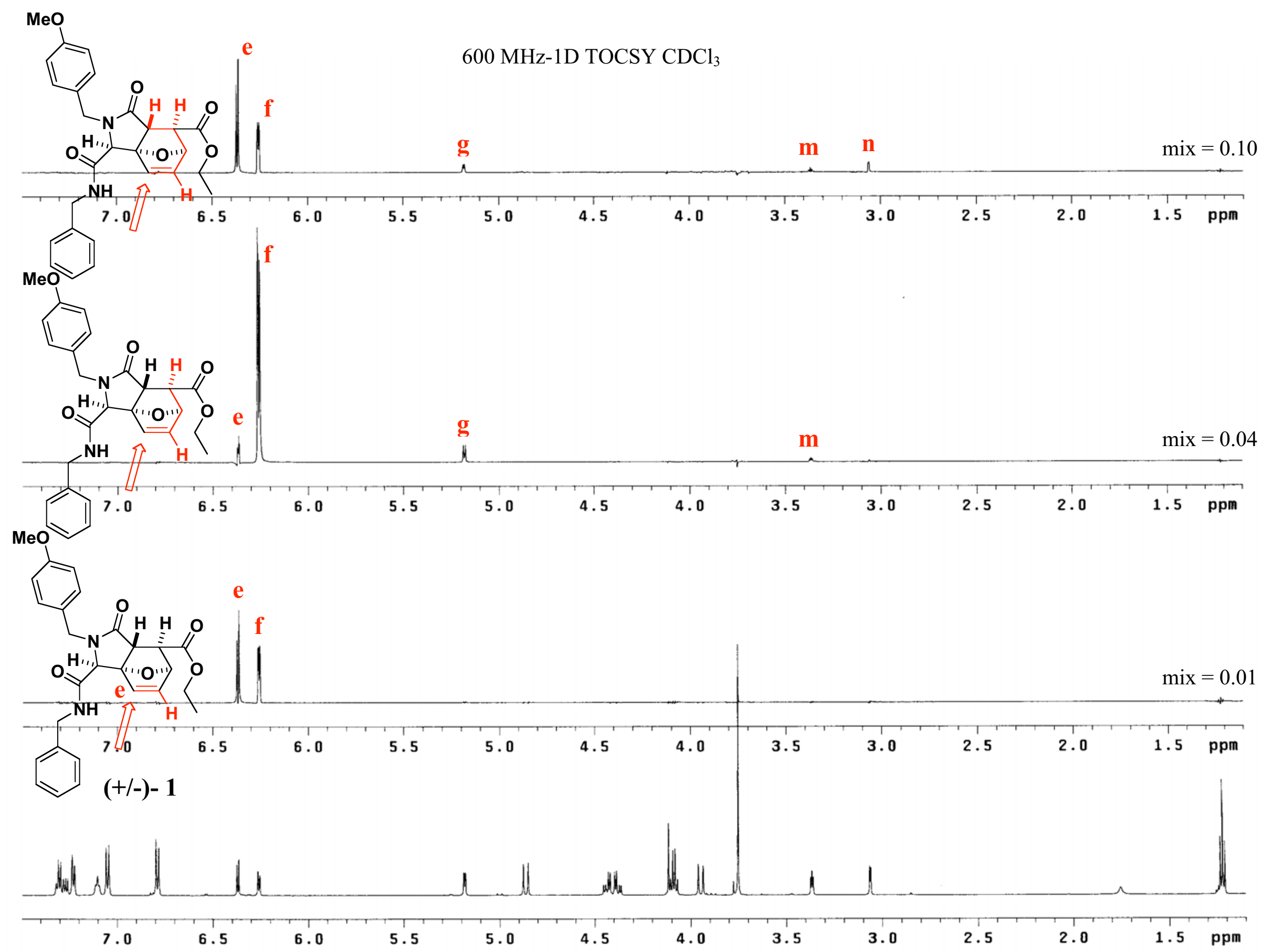


$600 \mathrm{MHz}-\mathrm{nOe} \mathrm{CDCl}_{3}$

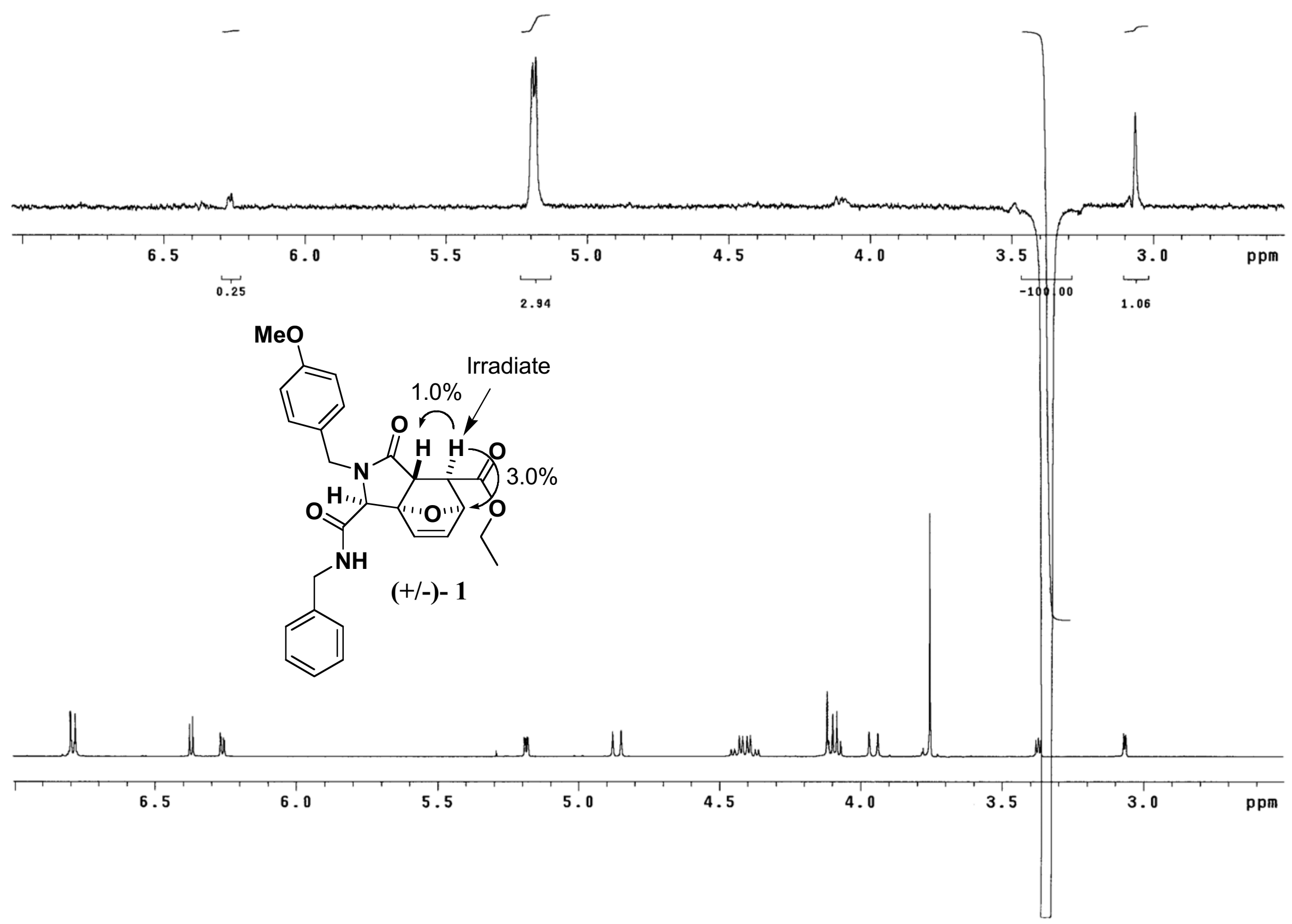


$400 \mathrm{MHz}-\mathrm{DEPT} \mathrm{CDCl}_{3}$ (+/-)-1
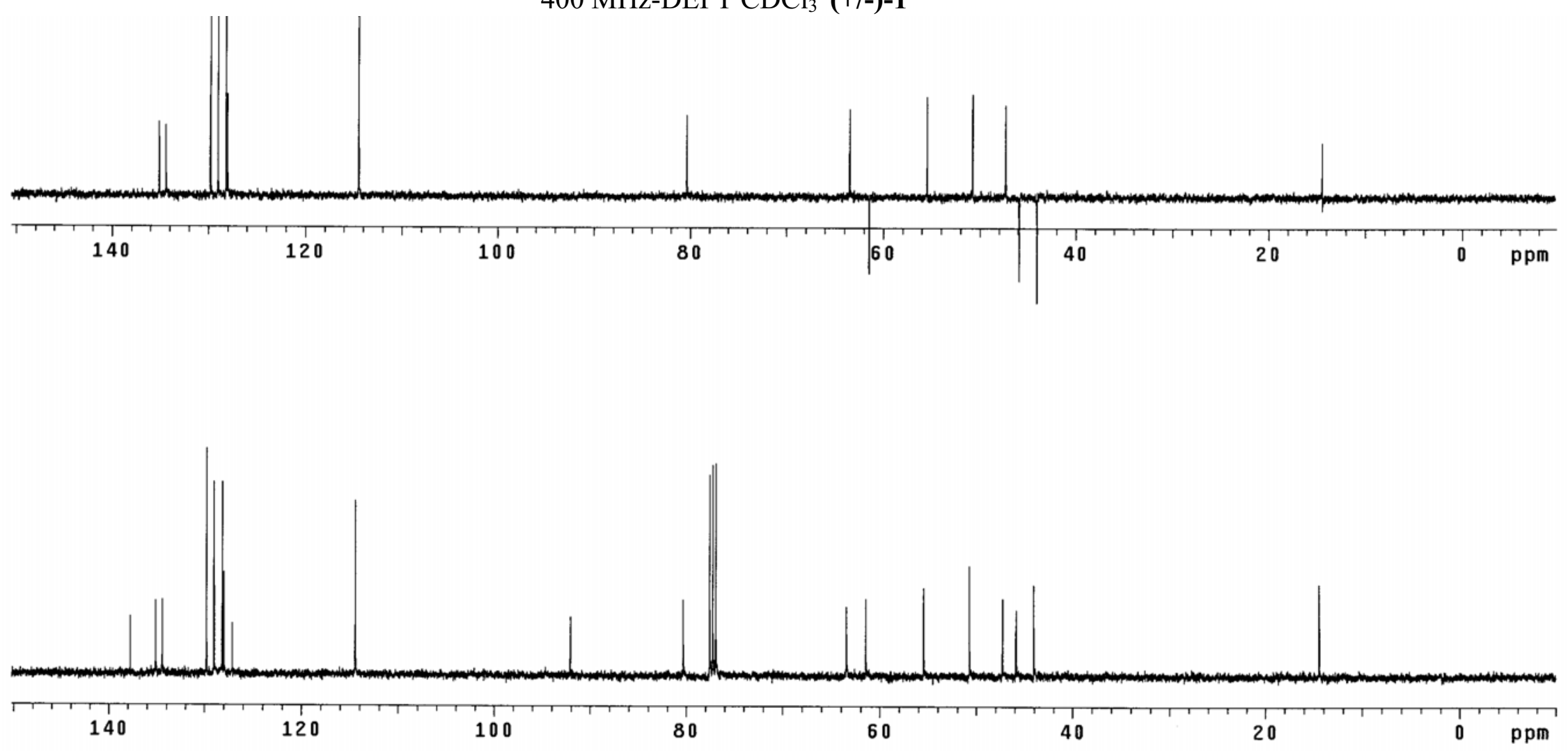

$400 \mathrm{MHz}^{13} \mathrm{C} \mathrm{CDCl}_{3}$ (+/-)-1

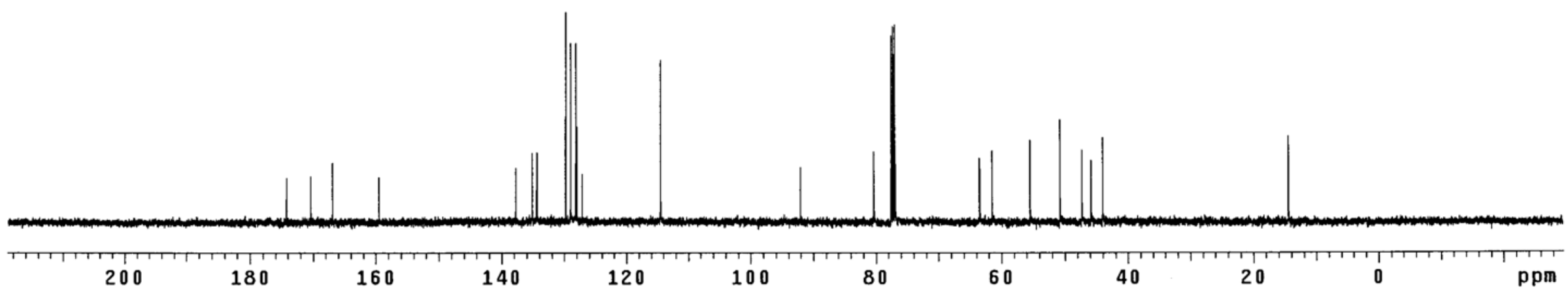


400 MHz-gHMQC $\mathrm{CDCl}_{3}$ (+/-)-1

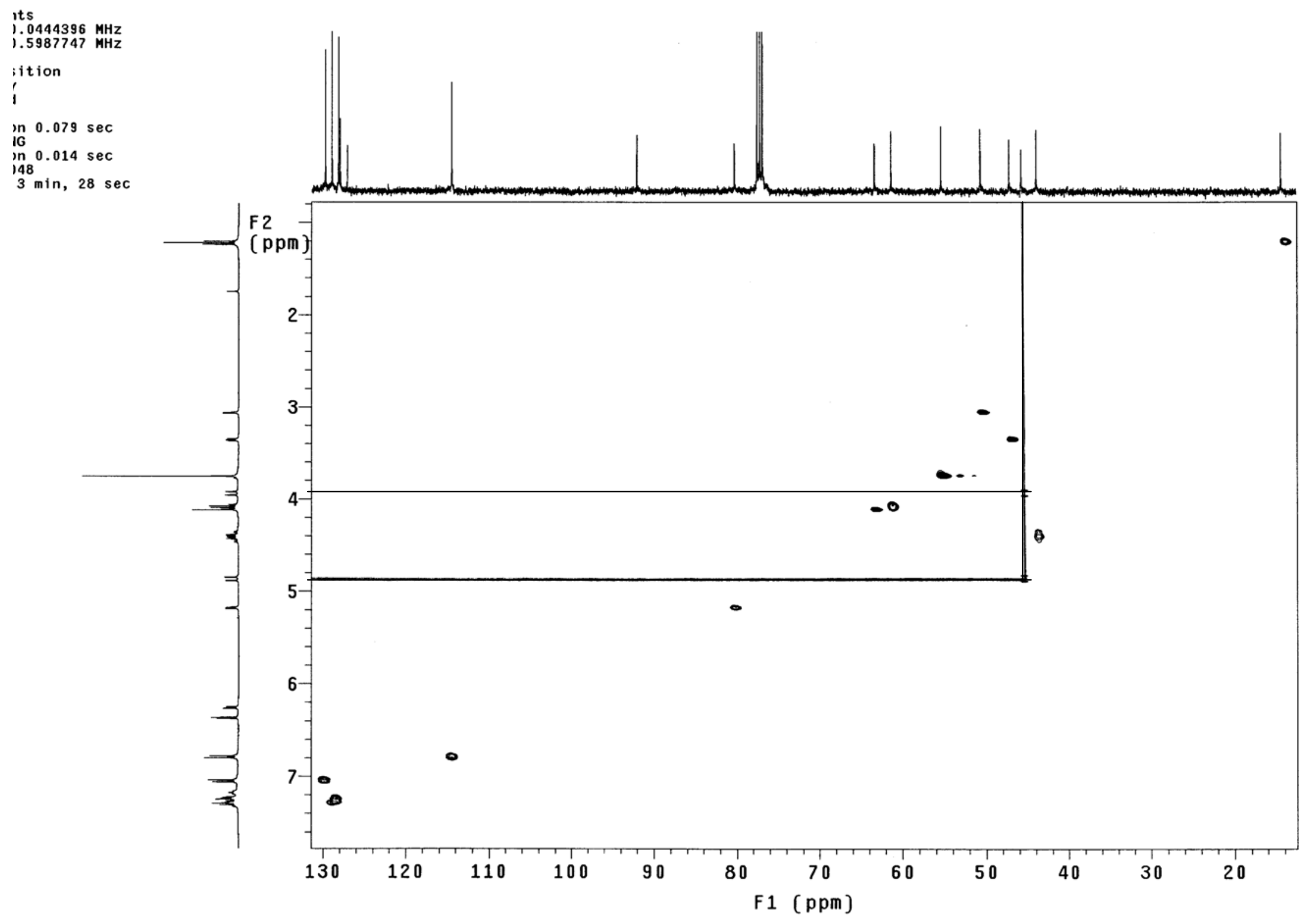




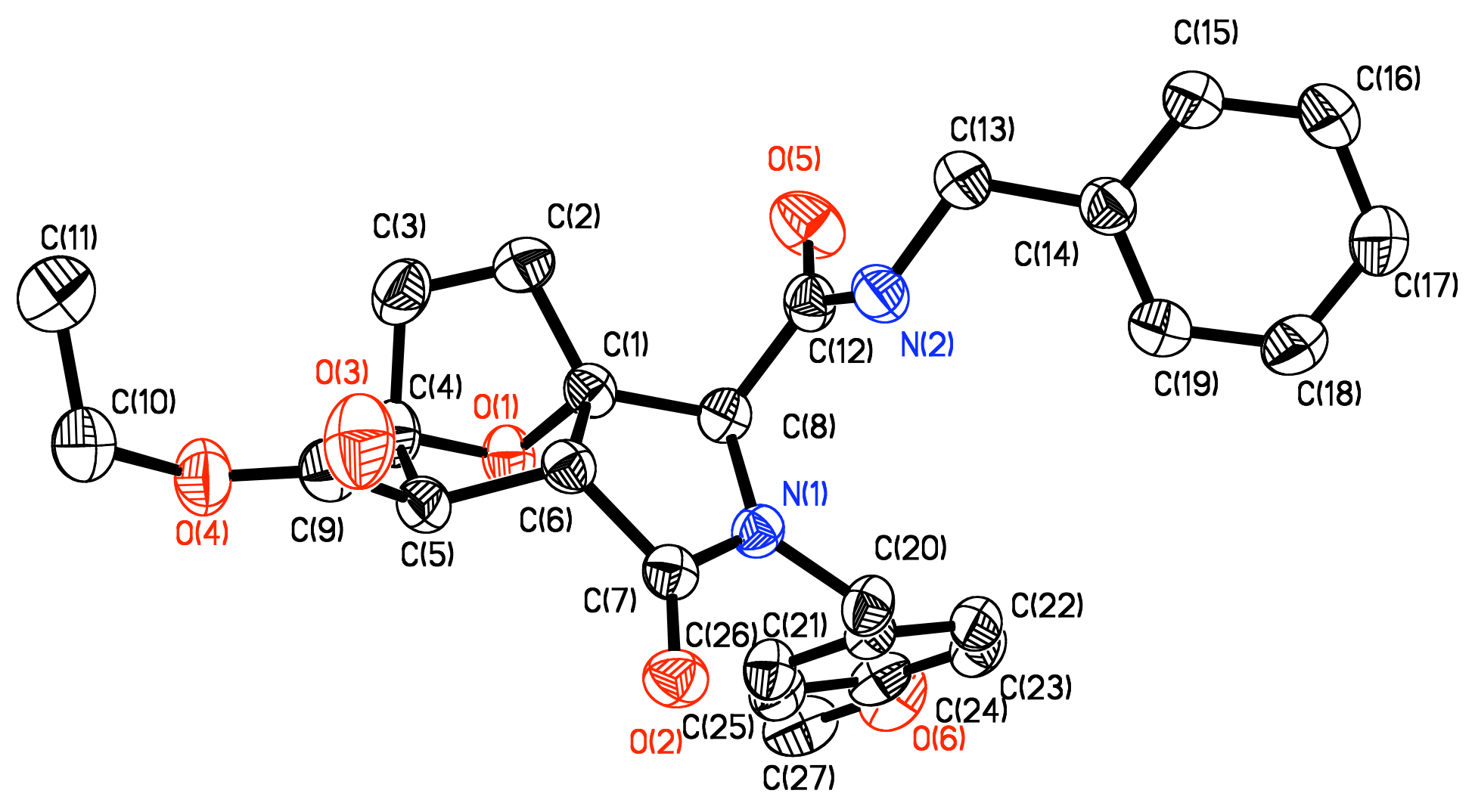




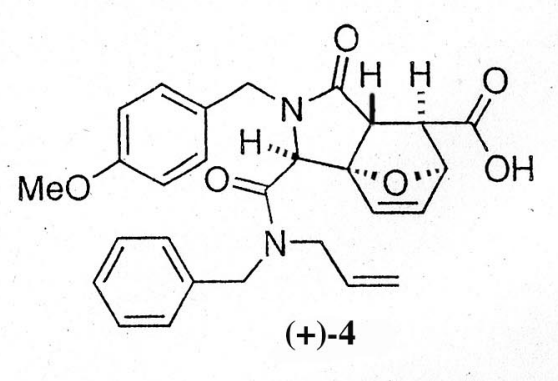




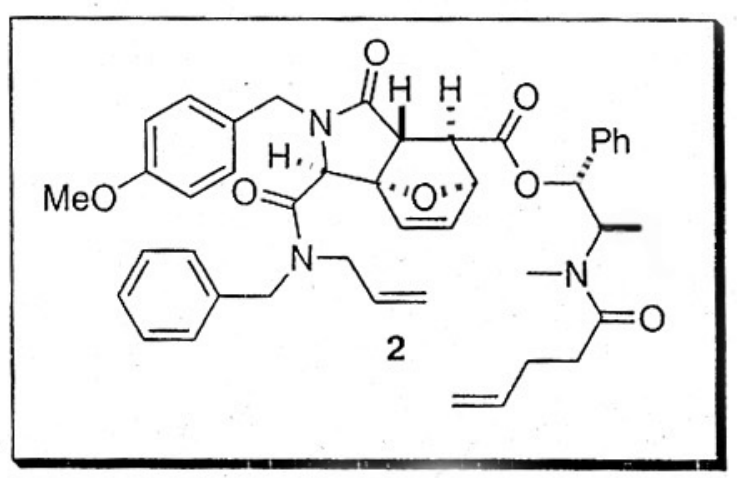




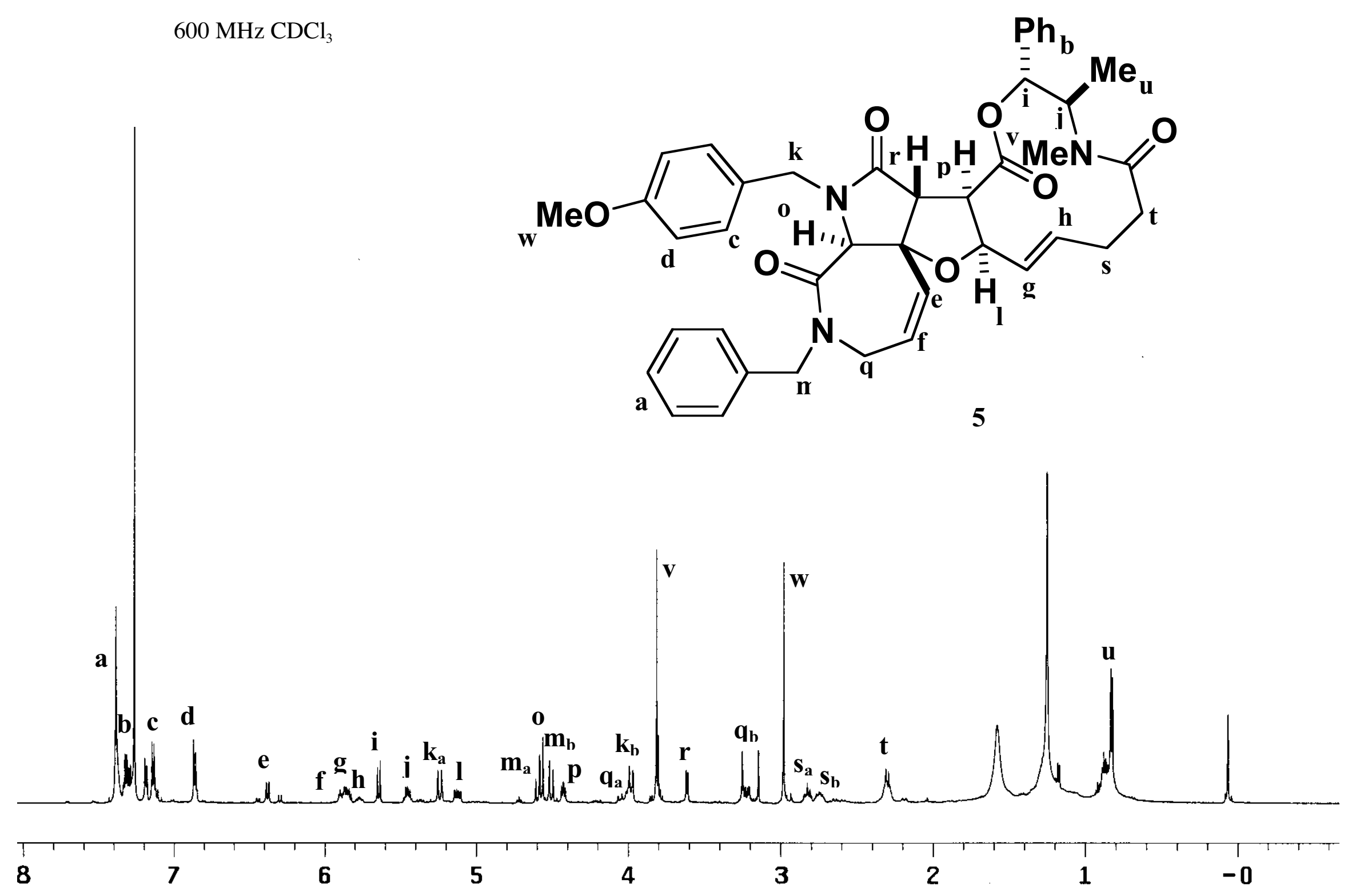




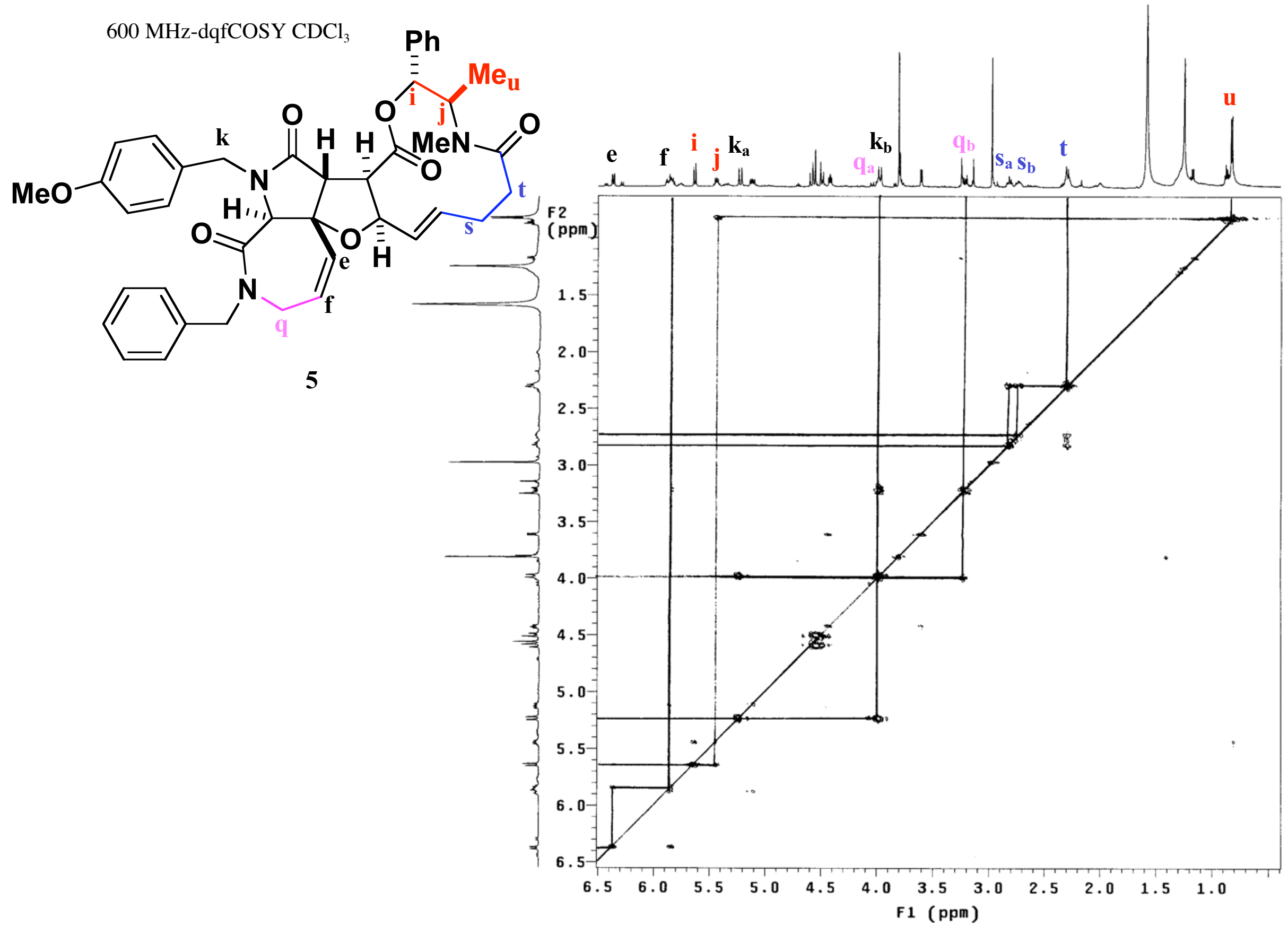




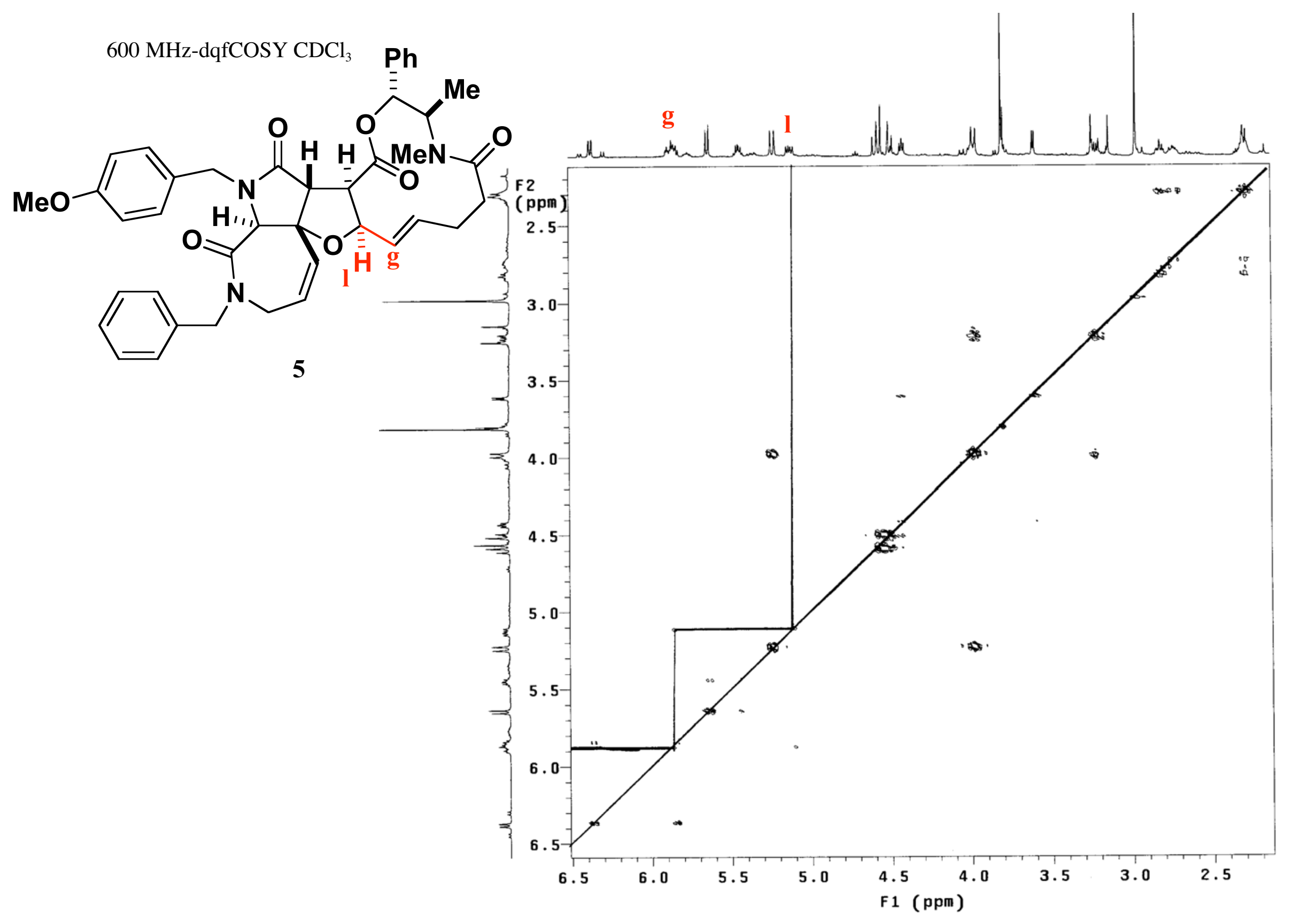


$600 \mathrm{MHz}-1 \mathrm{D}$ TOCSY $\mathrm{CDCl}_{3}$

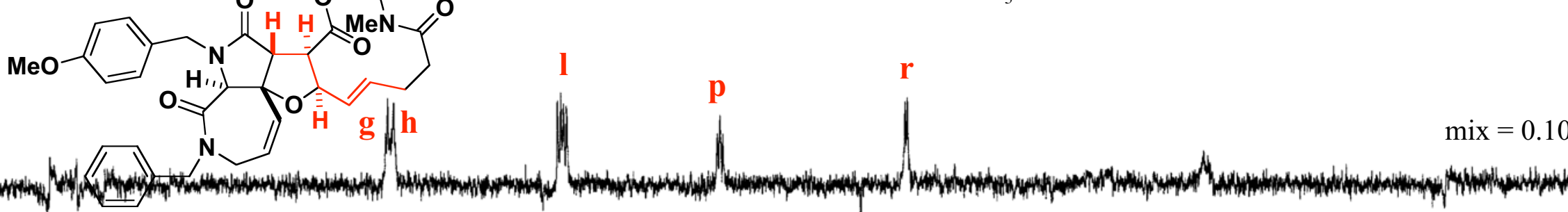
6

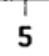

\begin{tabular}{l|l|l|}
1 &
\end{tabular}

1 ppm

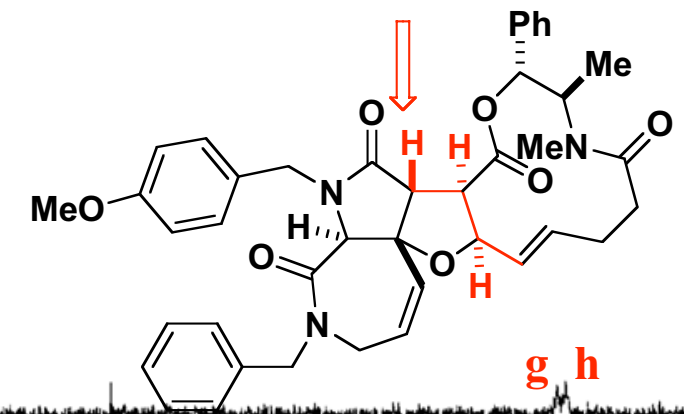

$\operatorname{mix}=0.04$

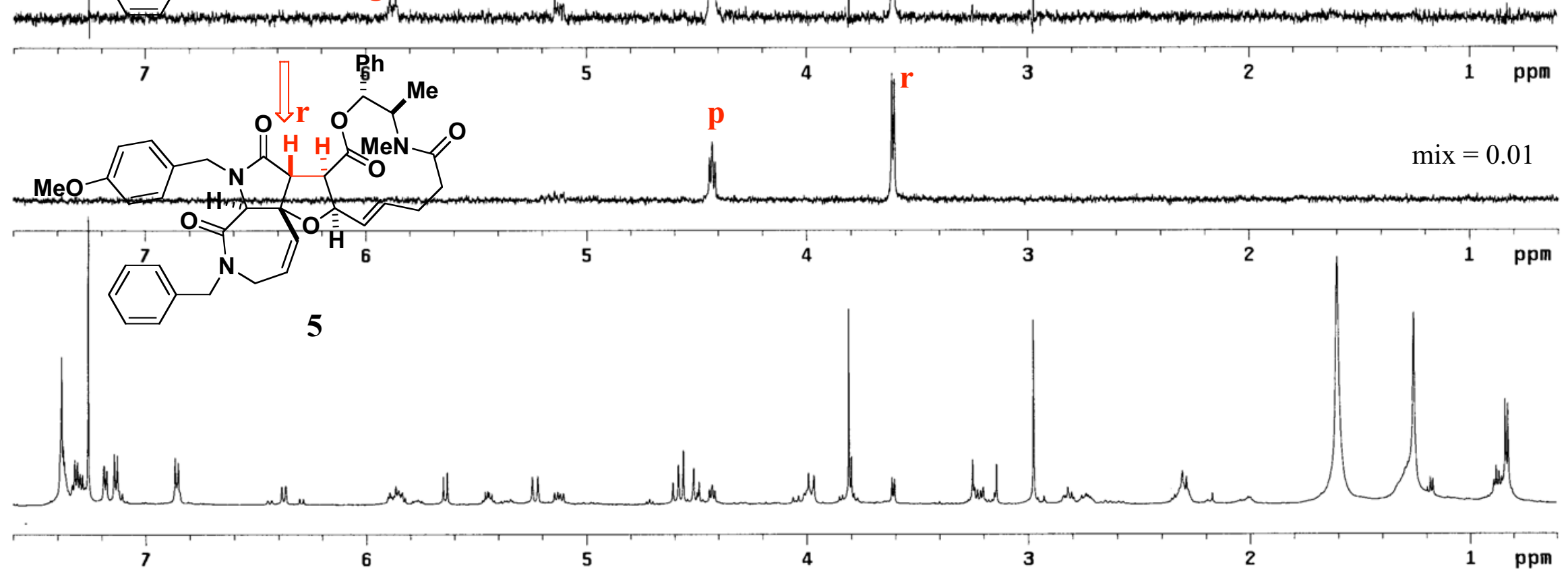



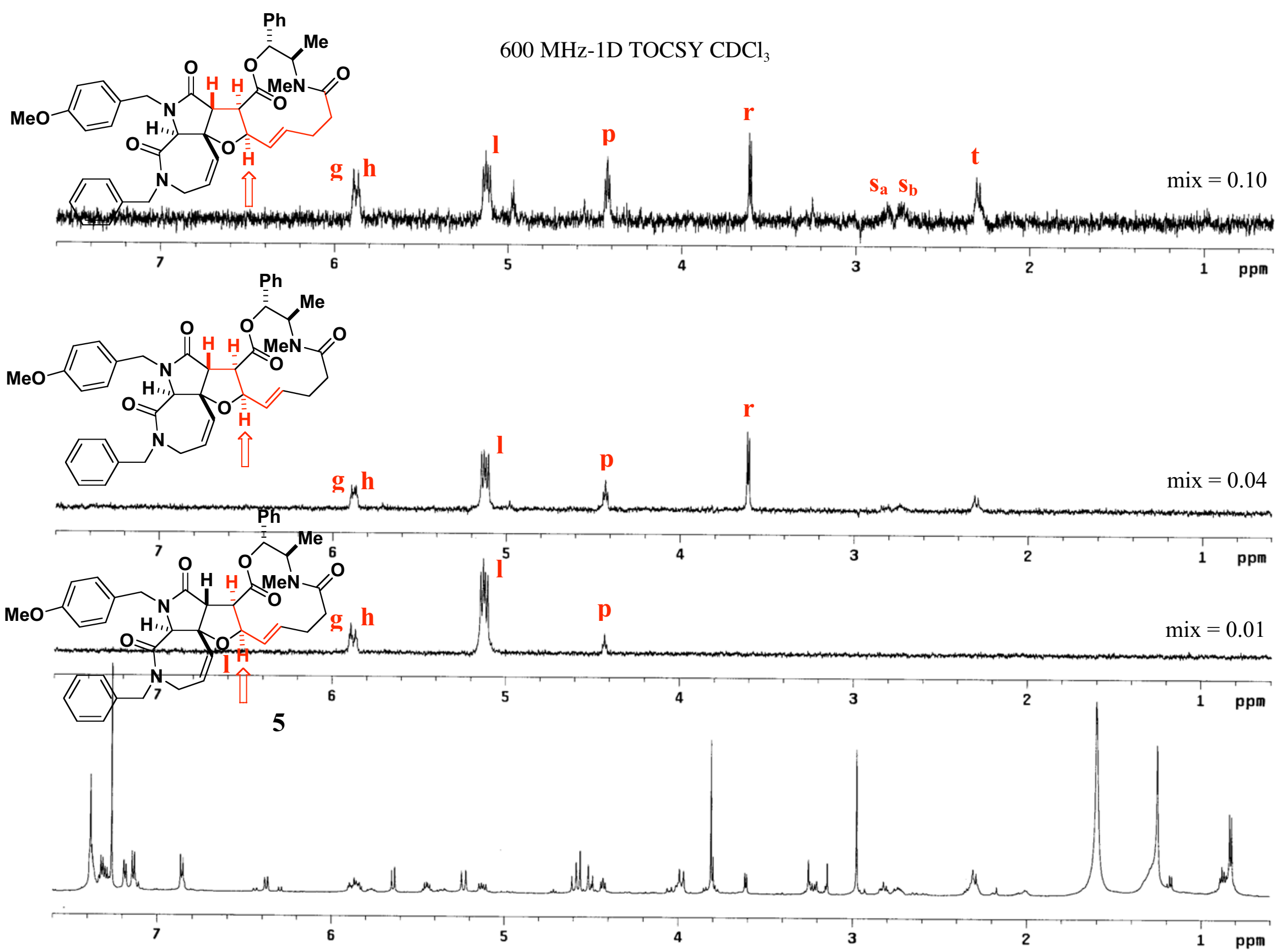


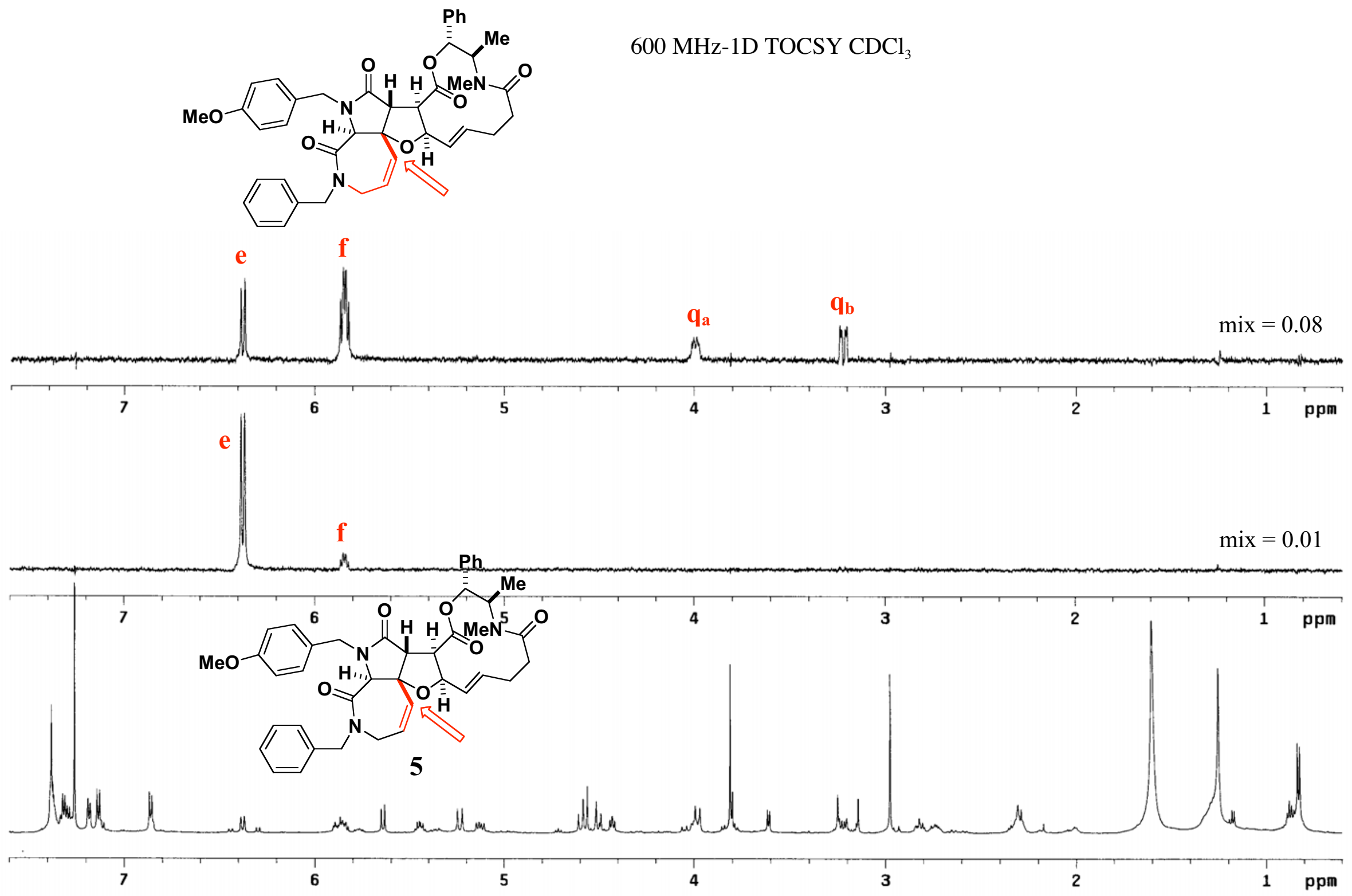



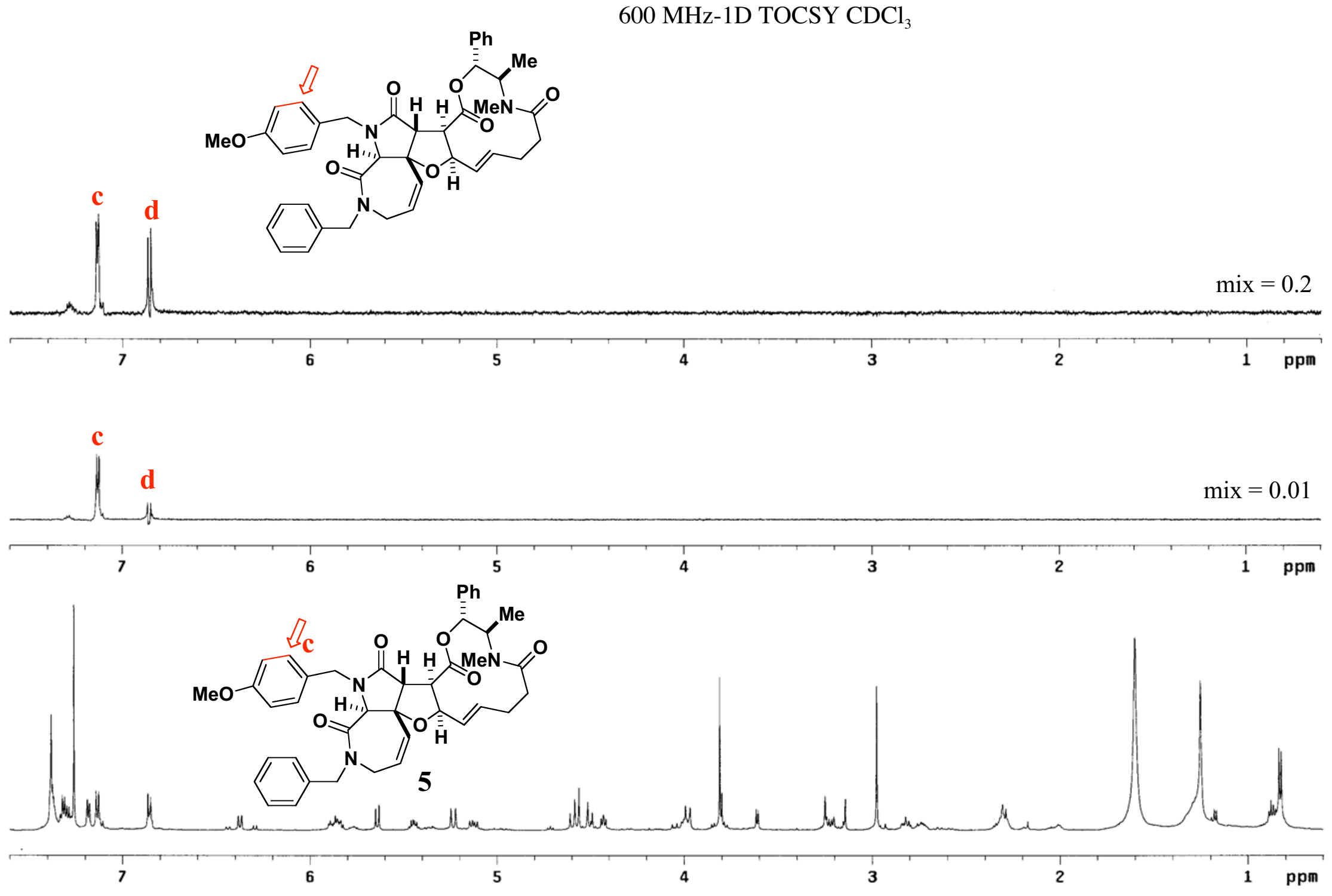

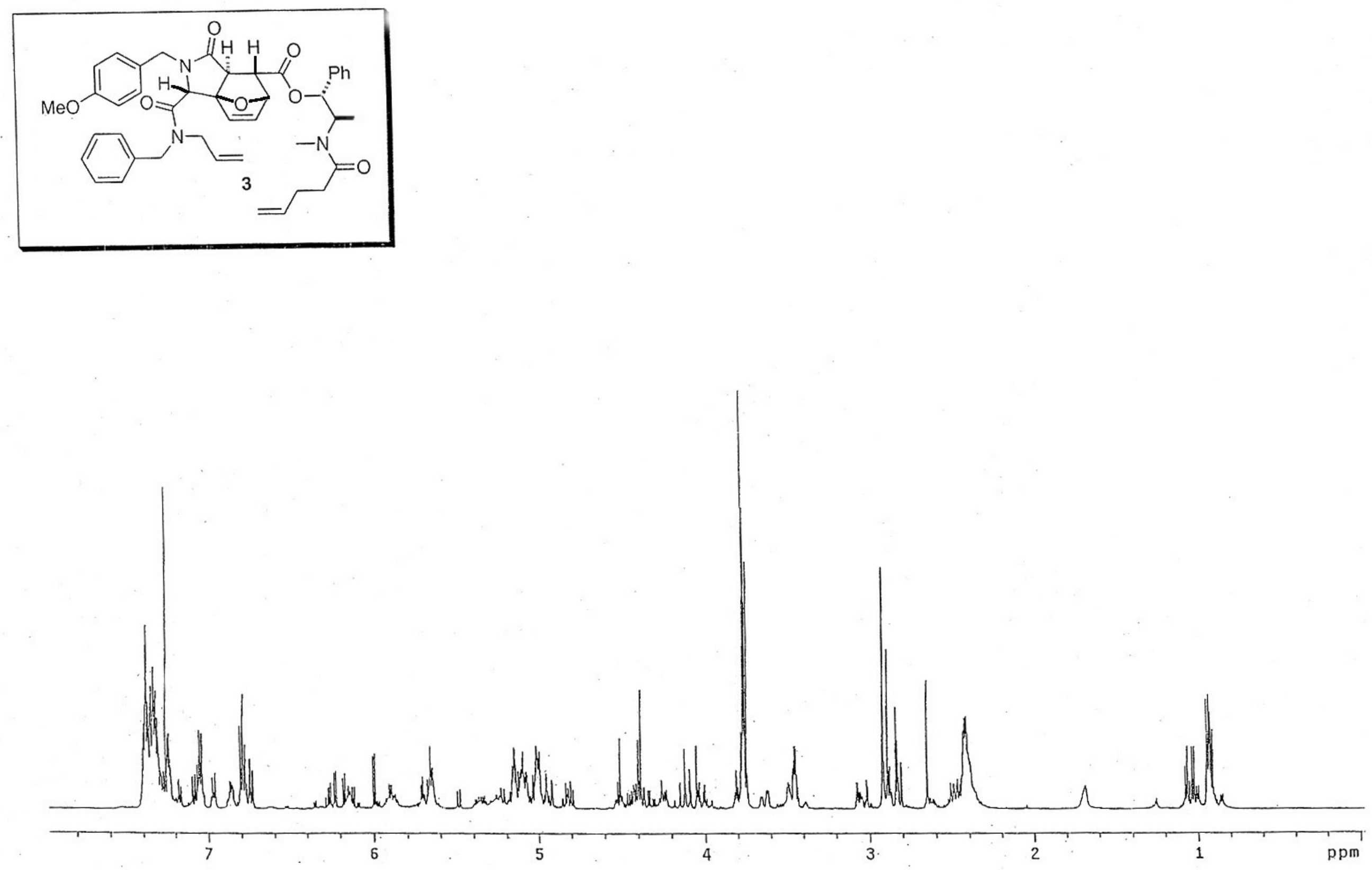

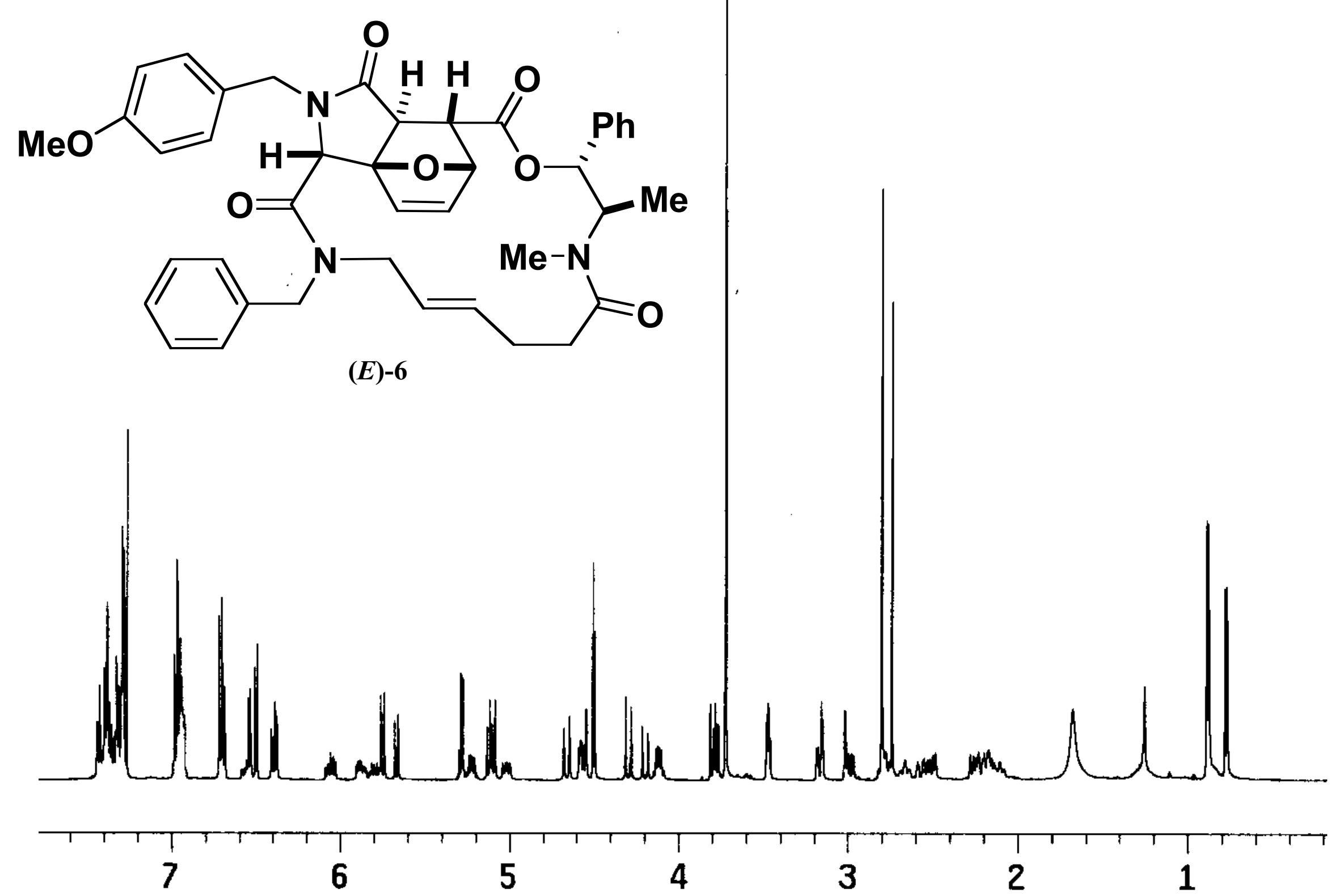


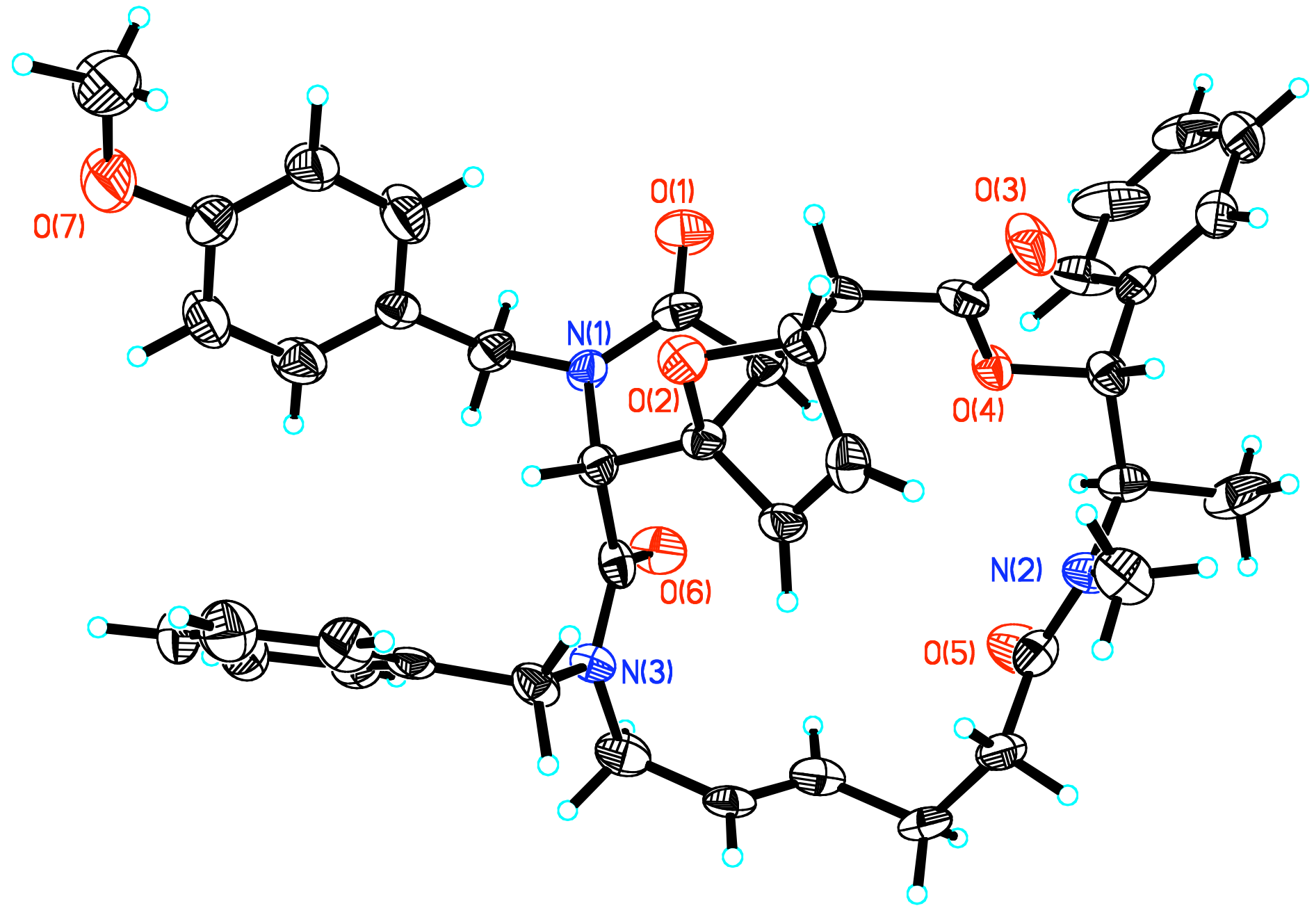


$600 \mathrm{MHz}^{-1} \mathrm{H} \mathrm{NMR} \mathrm{CDCl}_{3}$

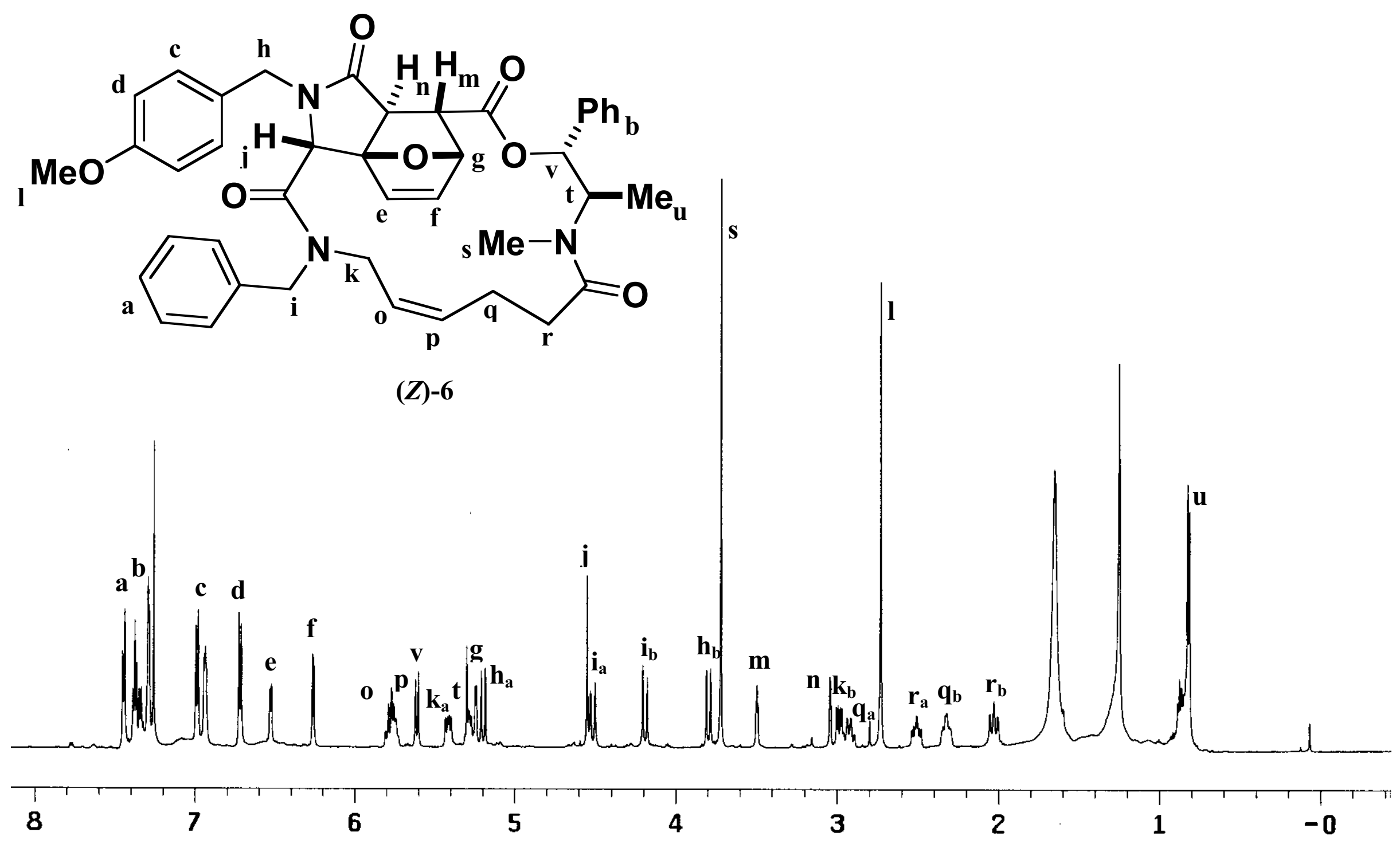


$600 \mathrm{MHz}$-dqfCOSY $\mathrm{CDCl}_{3}$

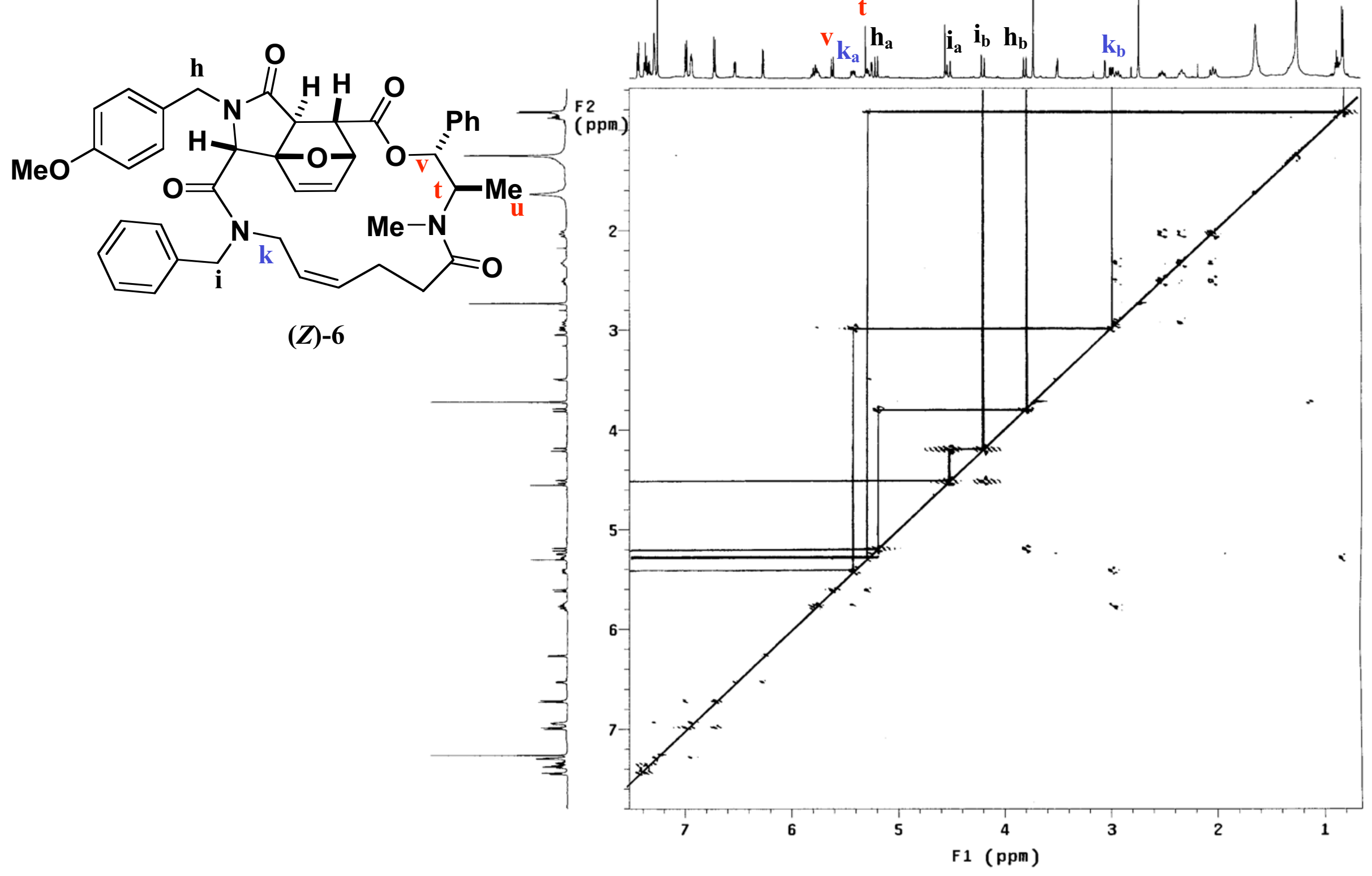


$600 \mathrm{MHz}-\mathrm{gCOSY} \mathrm{CDCl}_{3}$

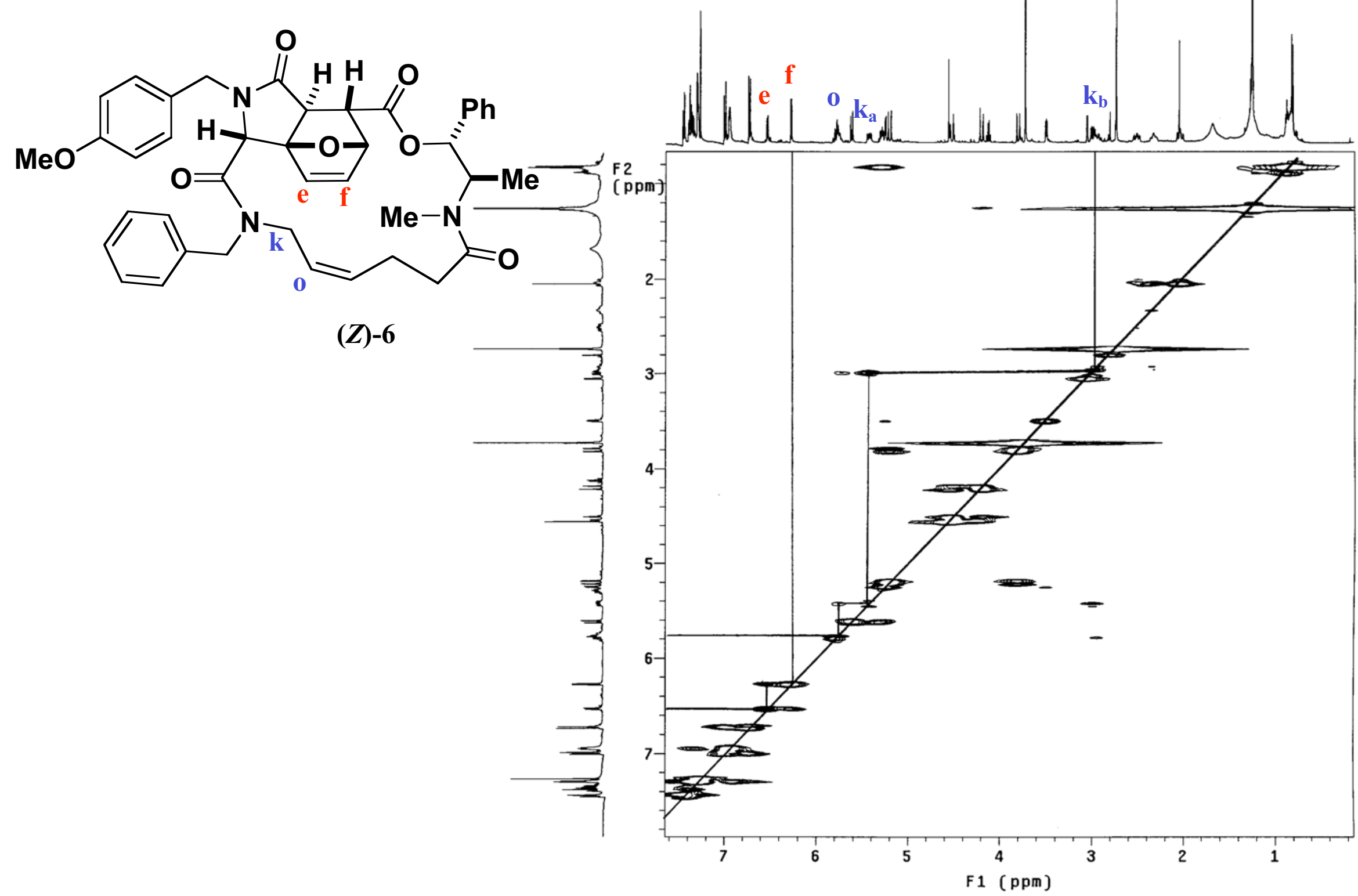


$600 \mathrm{MHz}-1 \mathrm{D}$ TOCSY $\mathrm{CDCl}_{3}$

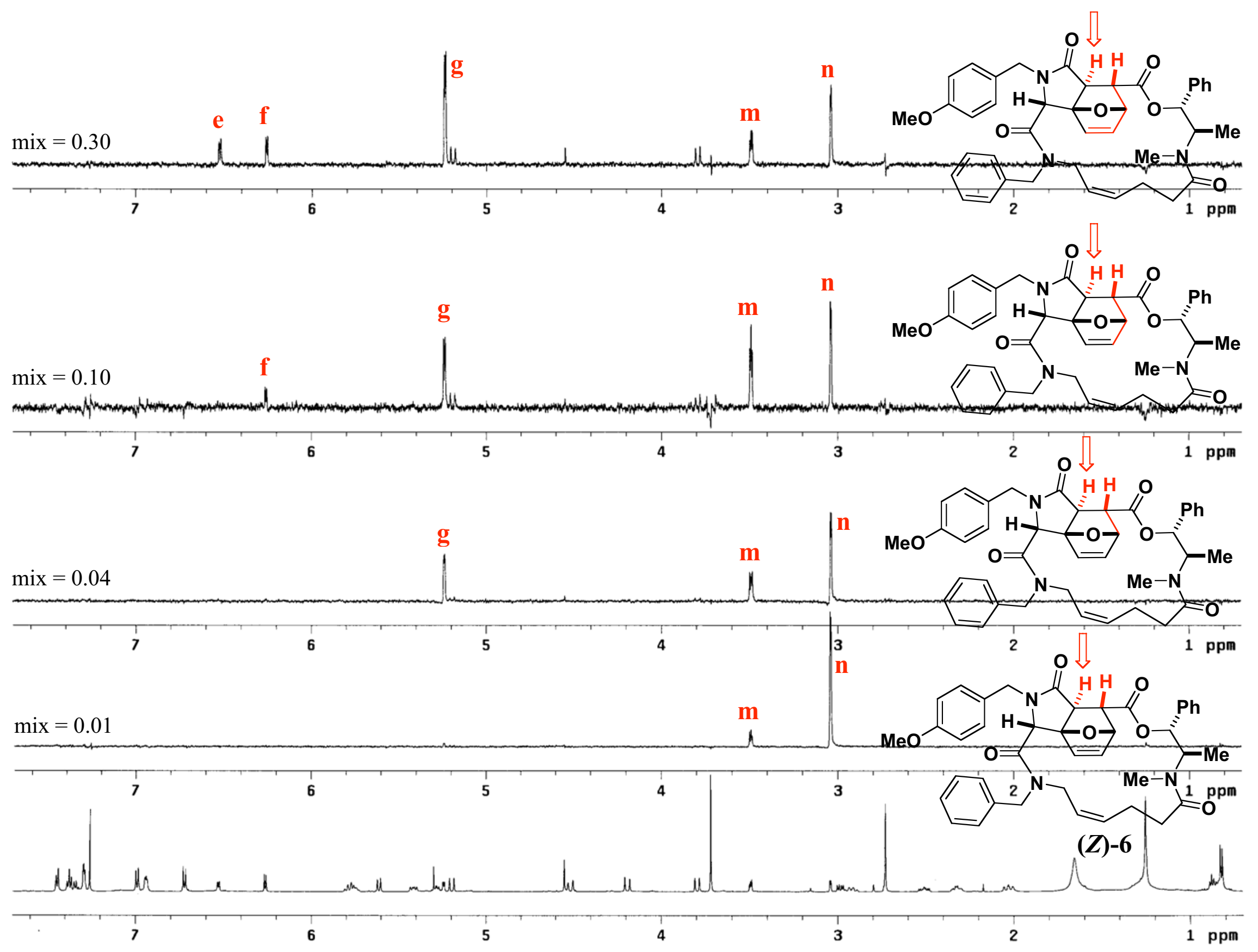


$600 \mathrm{MHz}-1 \mathrm{D}$ TOCSY $\mathrm{CDCl}_{3}$
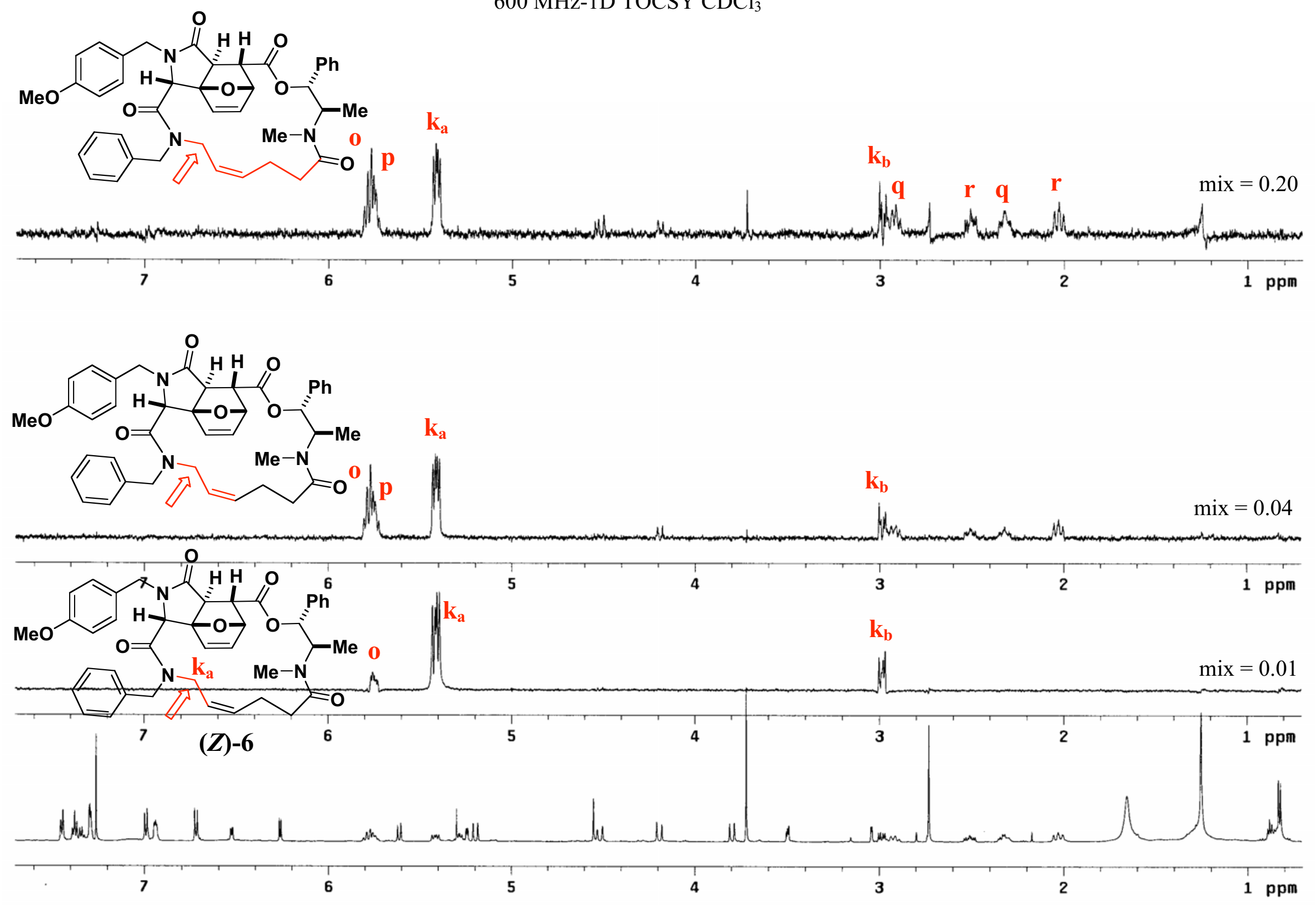
$600 \mathrm{MHz}-\mathrm{nOe} \mathrm{CDCl}_{3}$

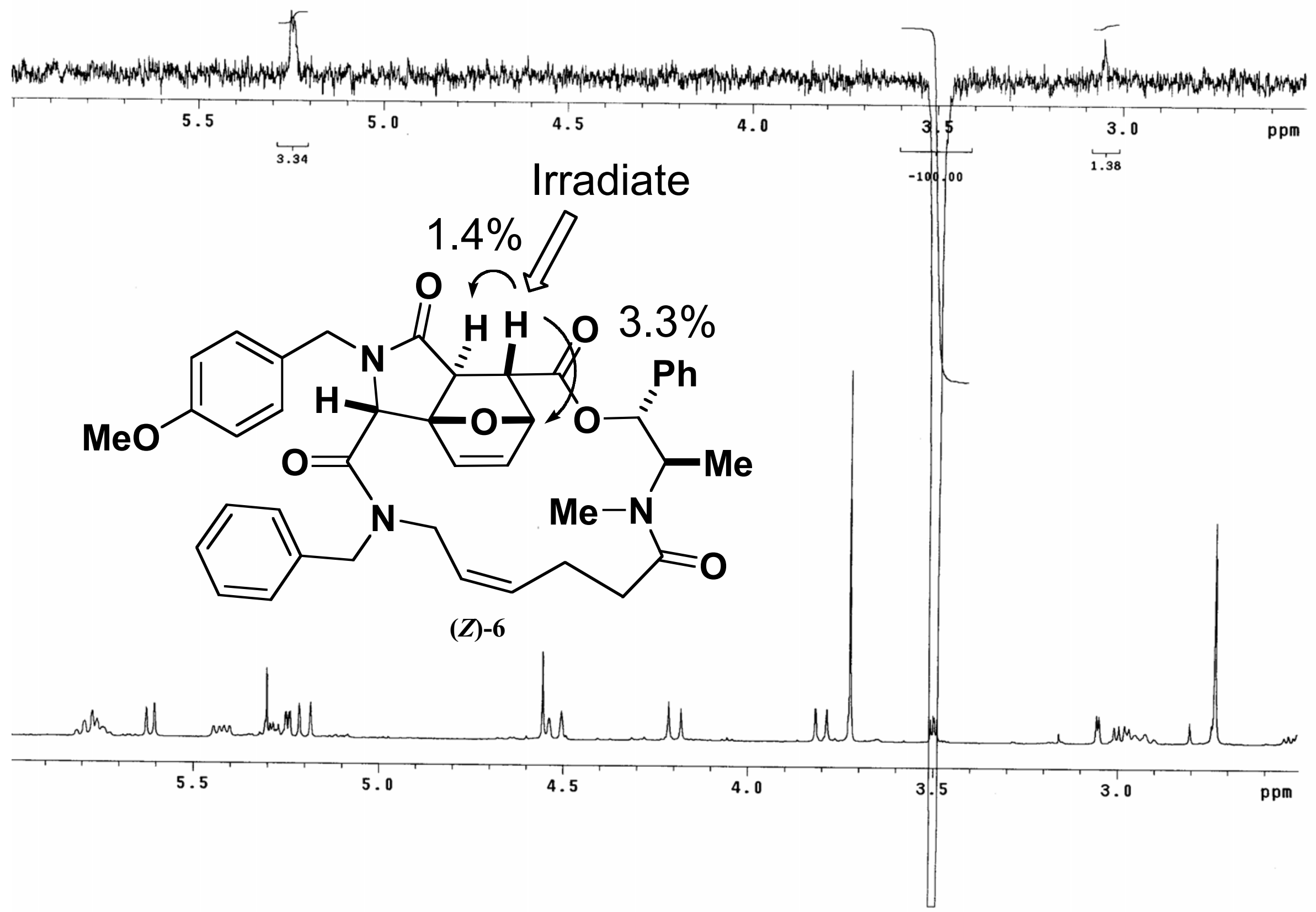




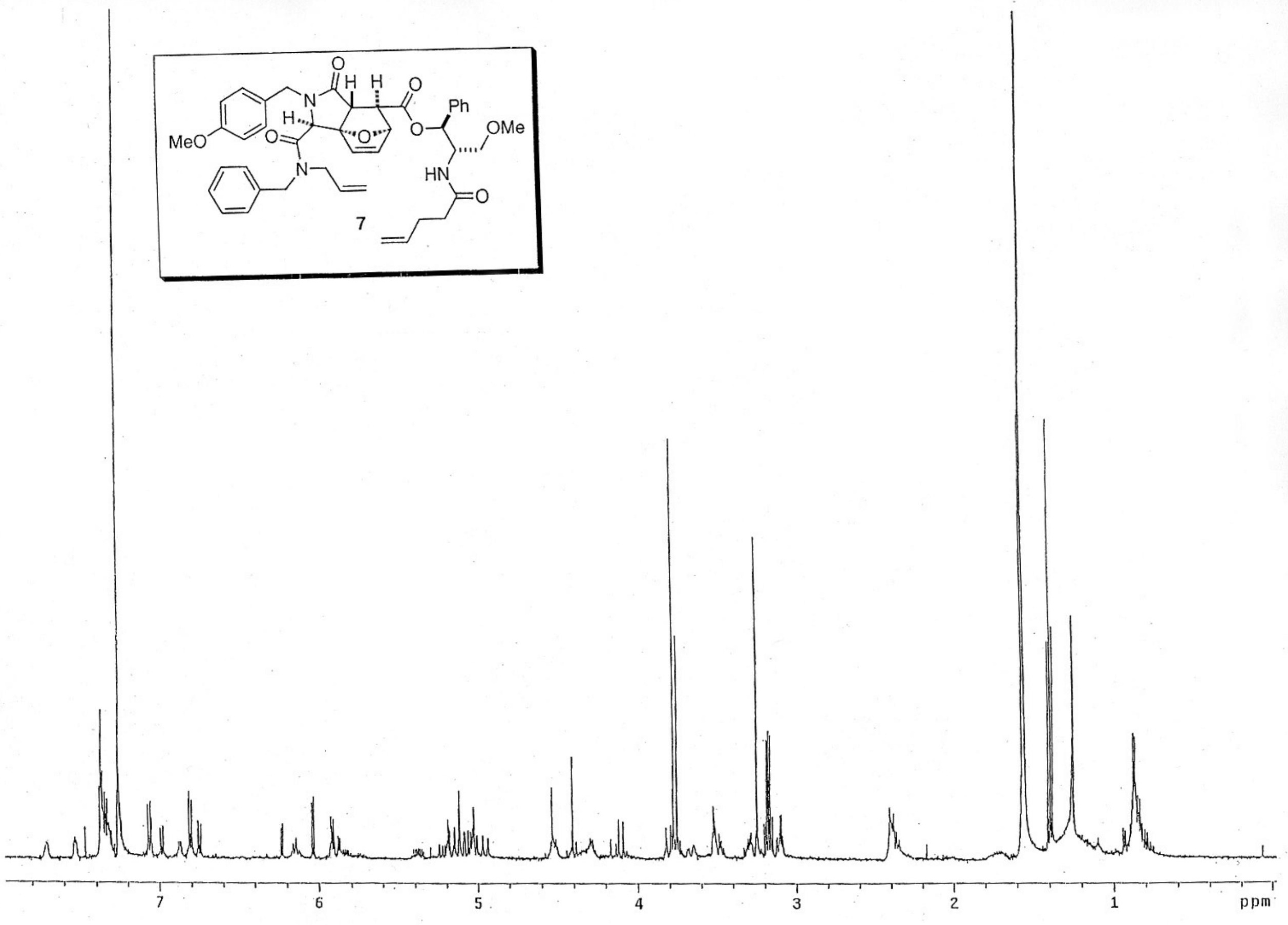



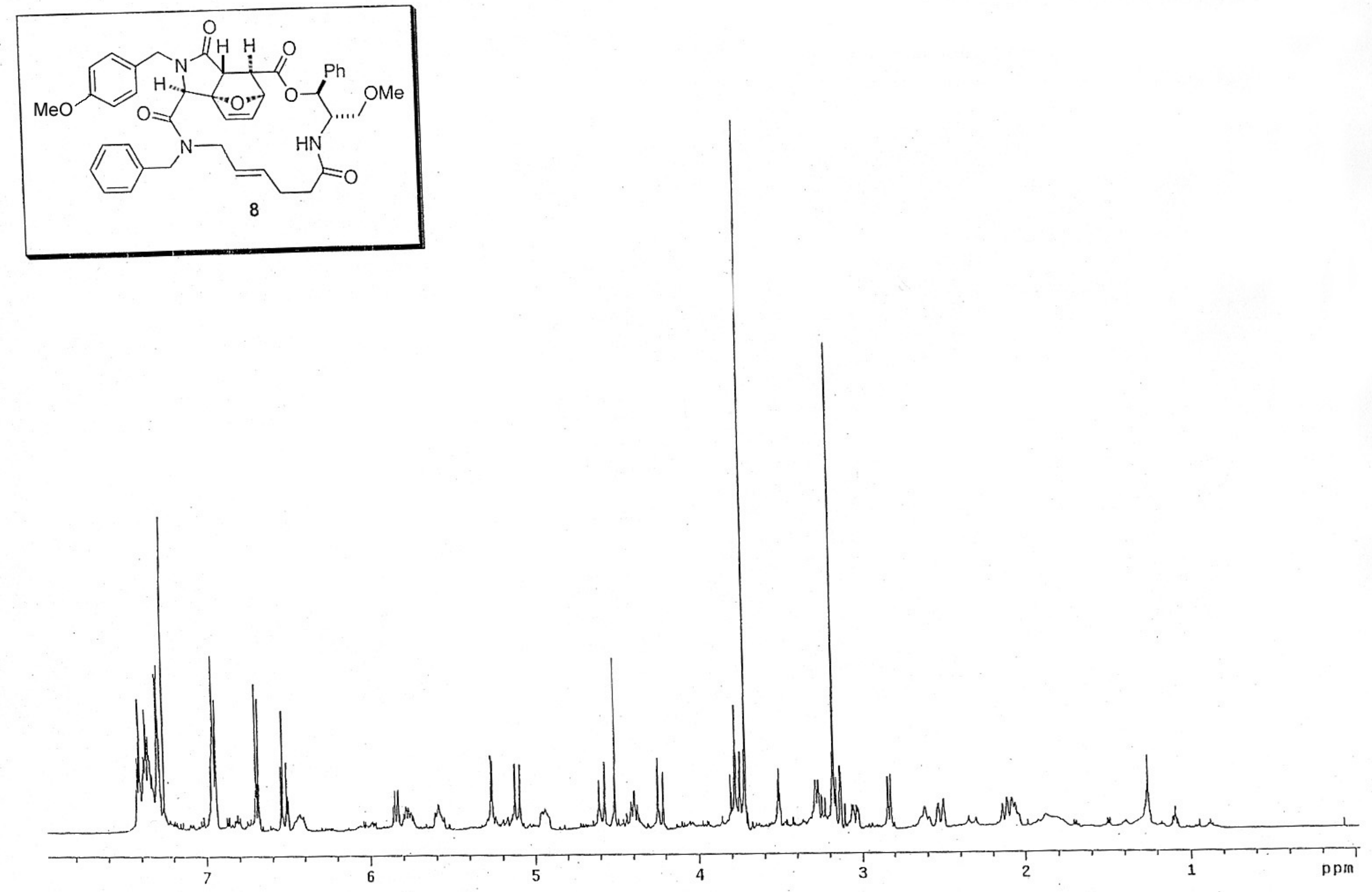


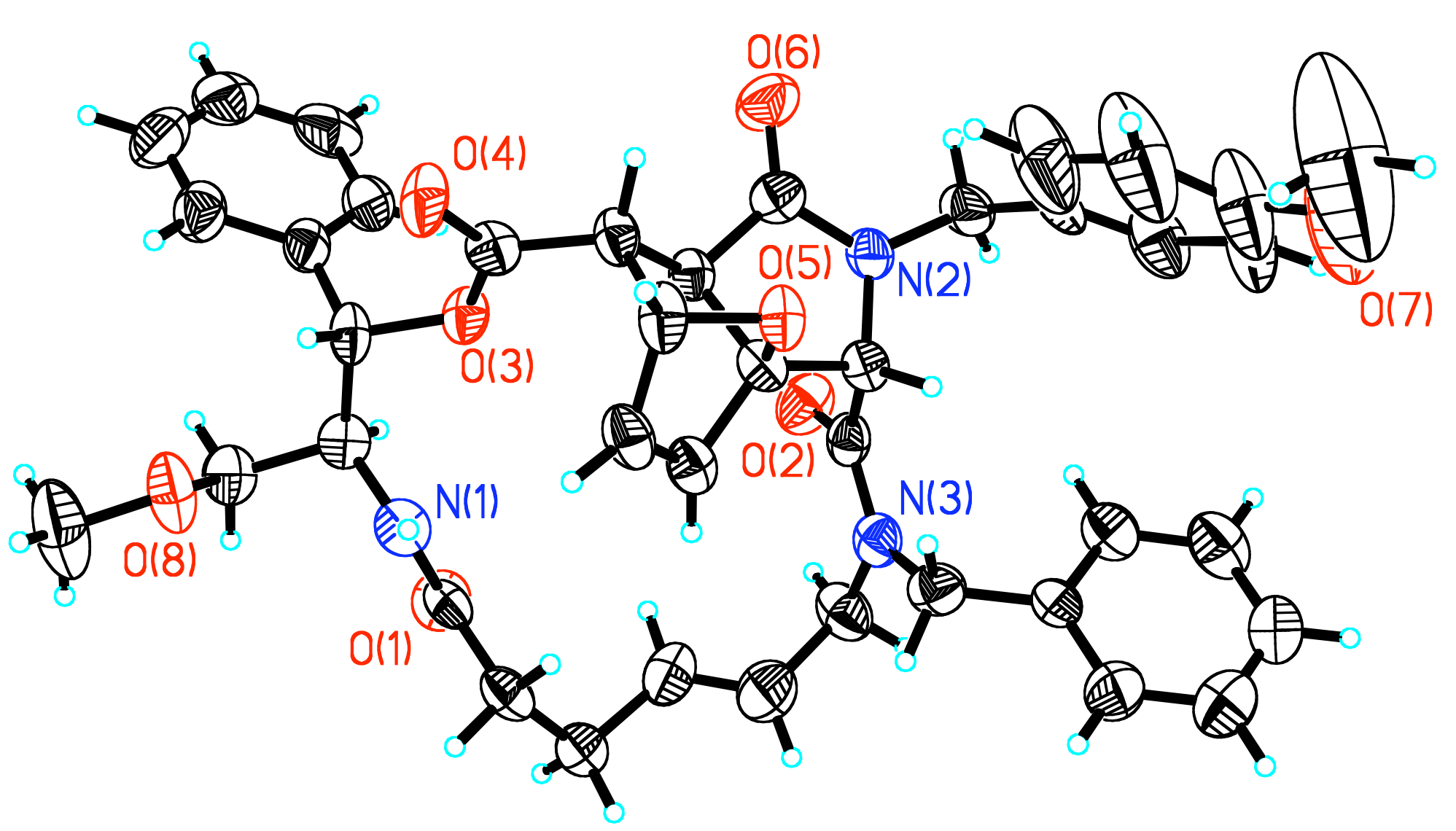



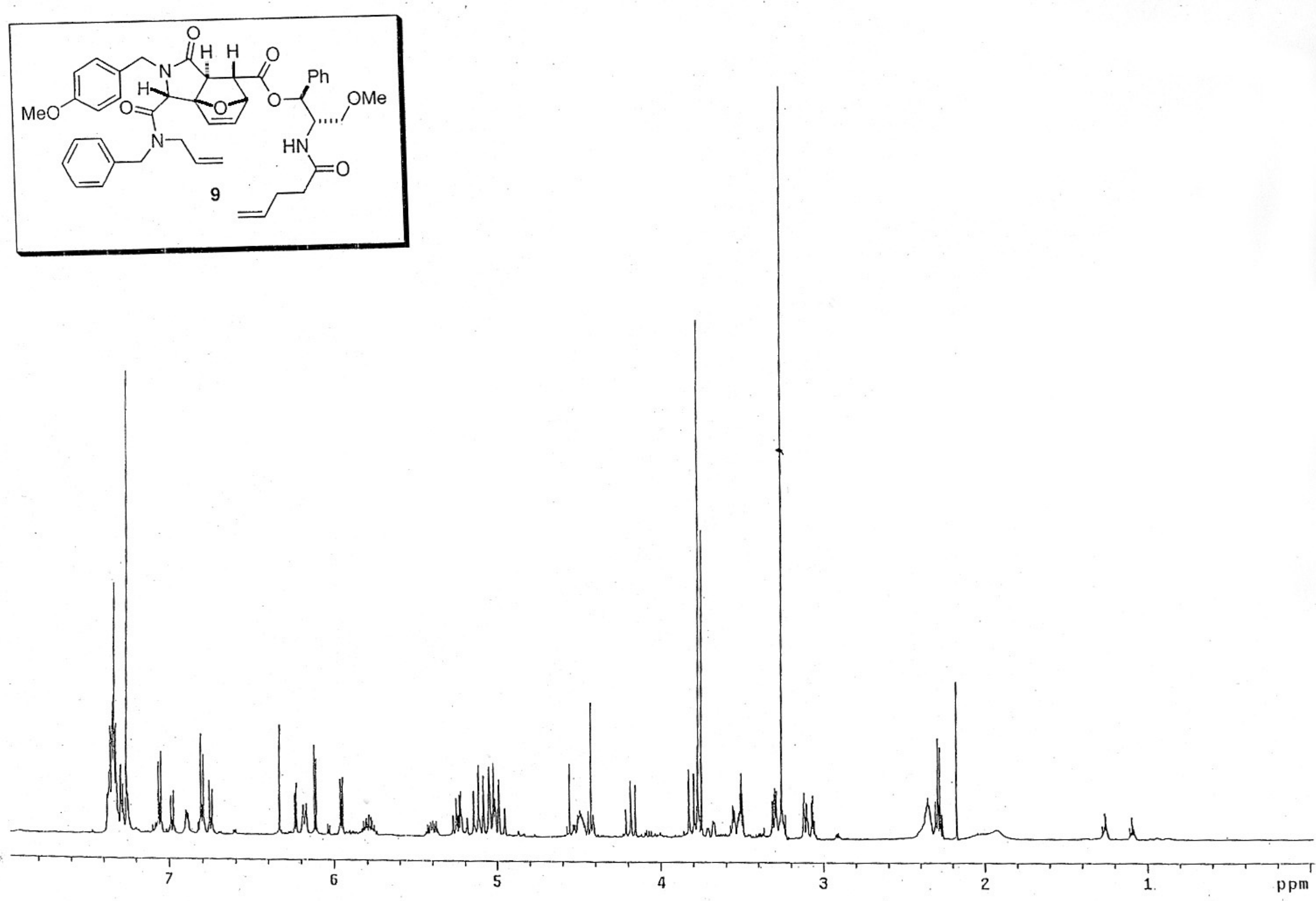

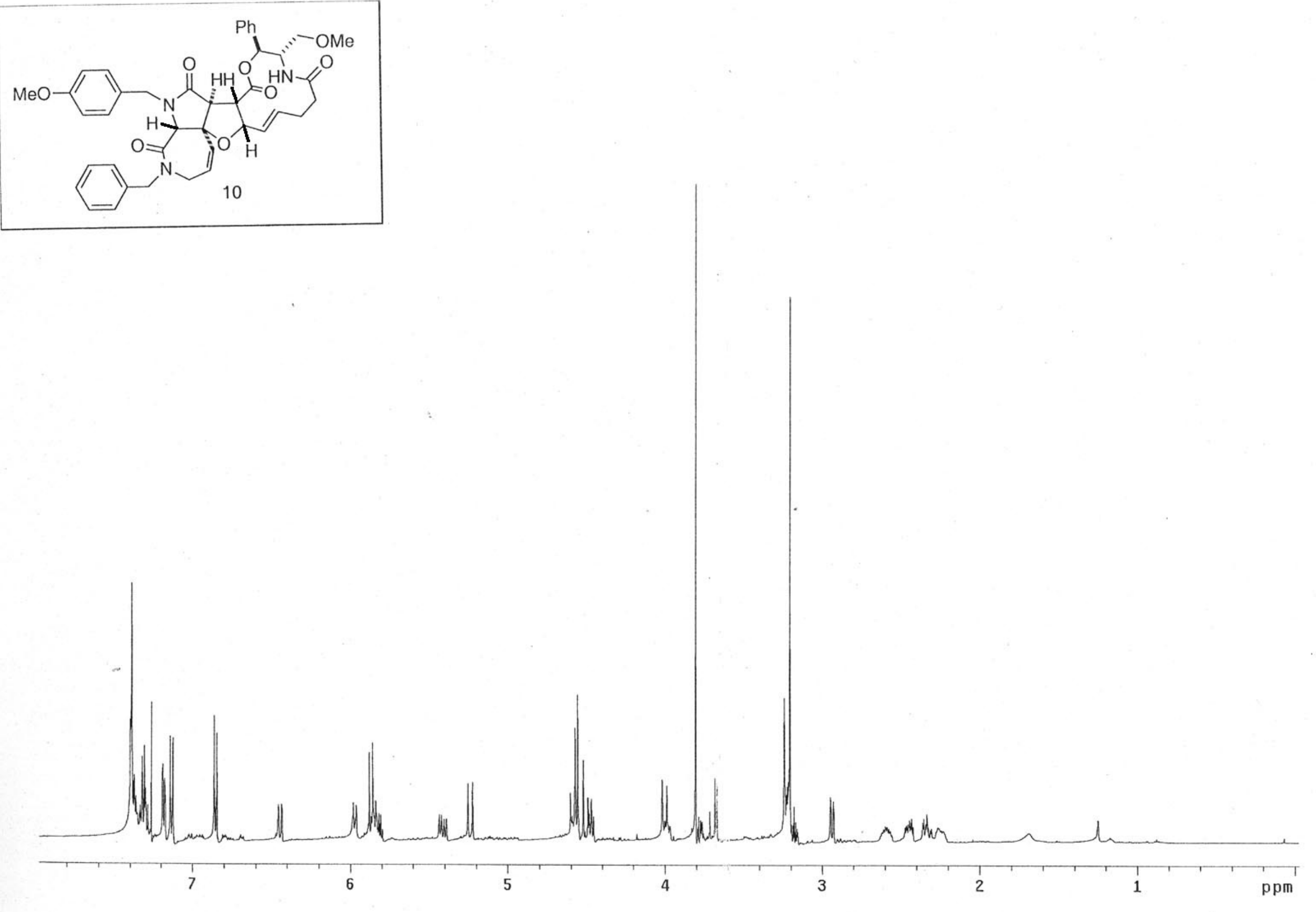


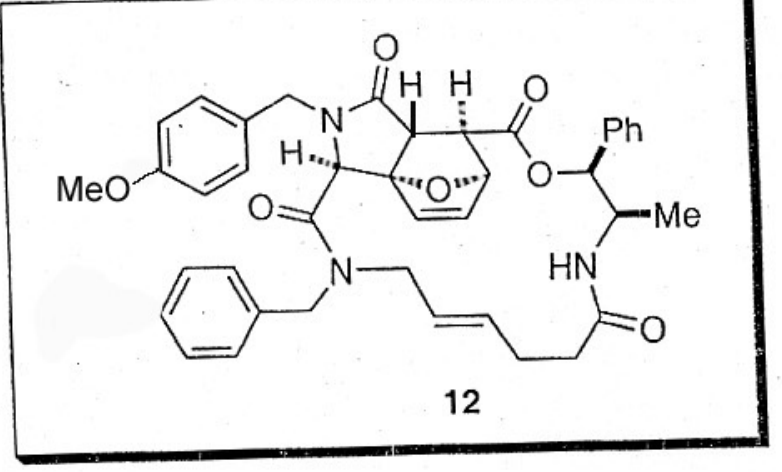

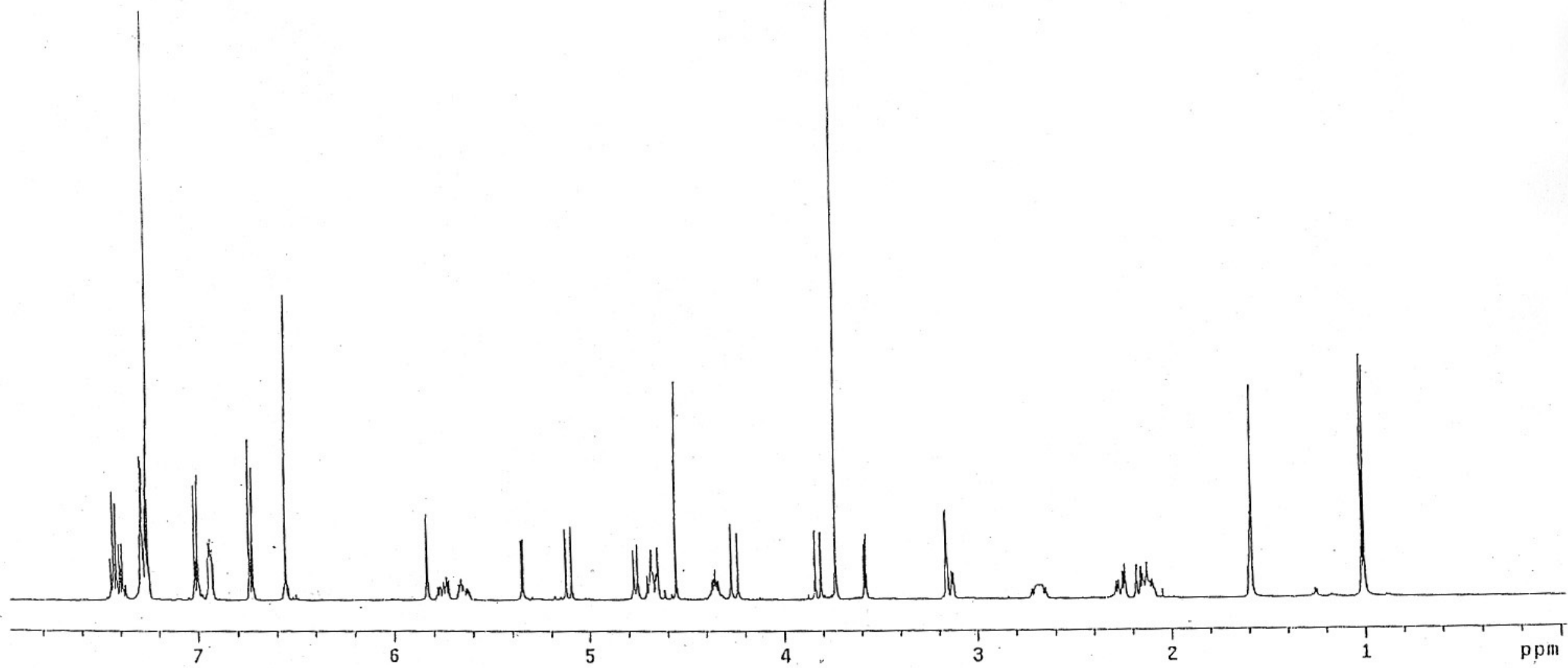




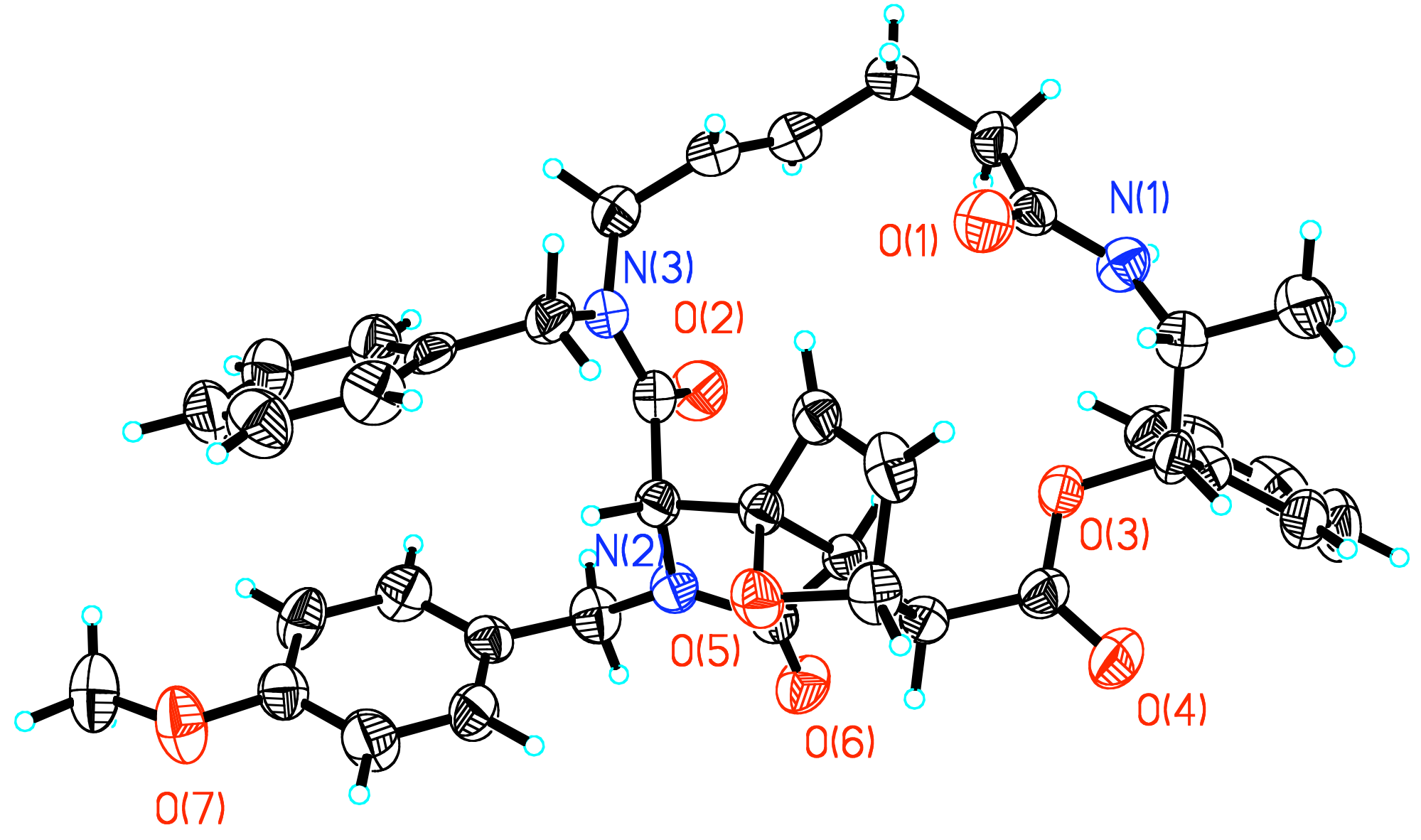



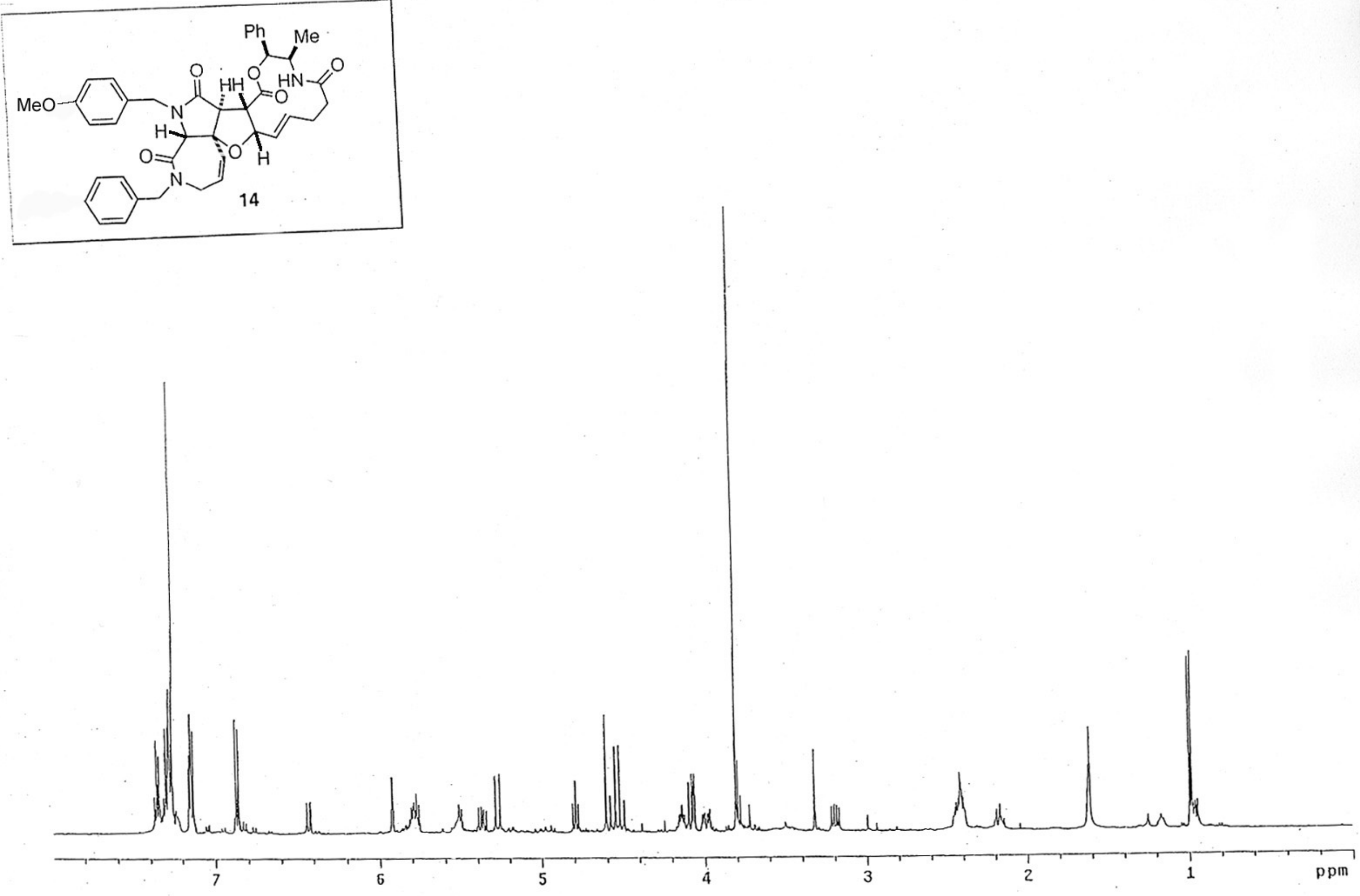


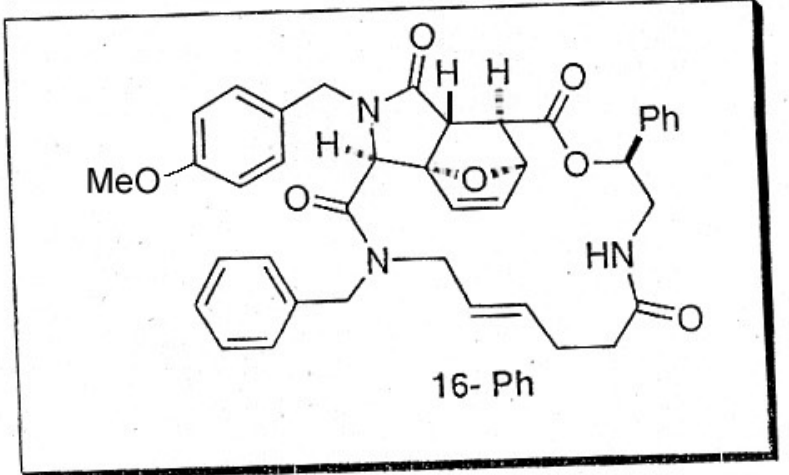




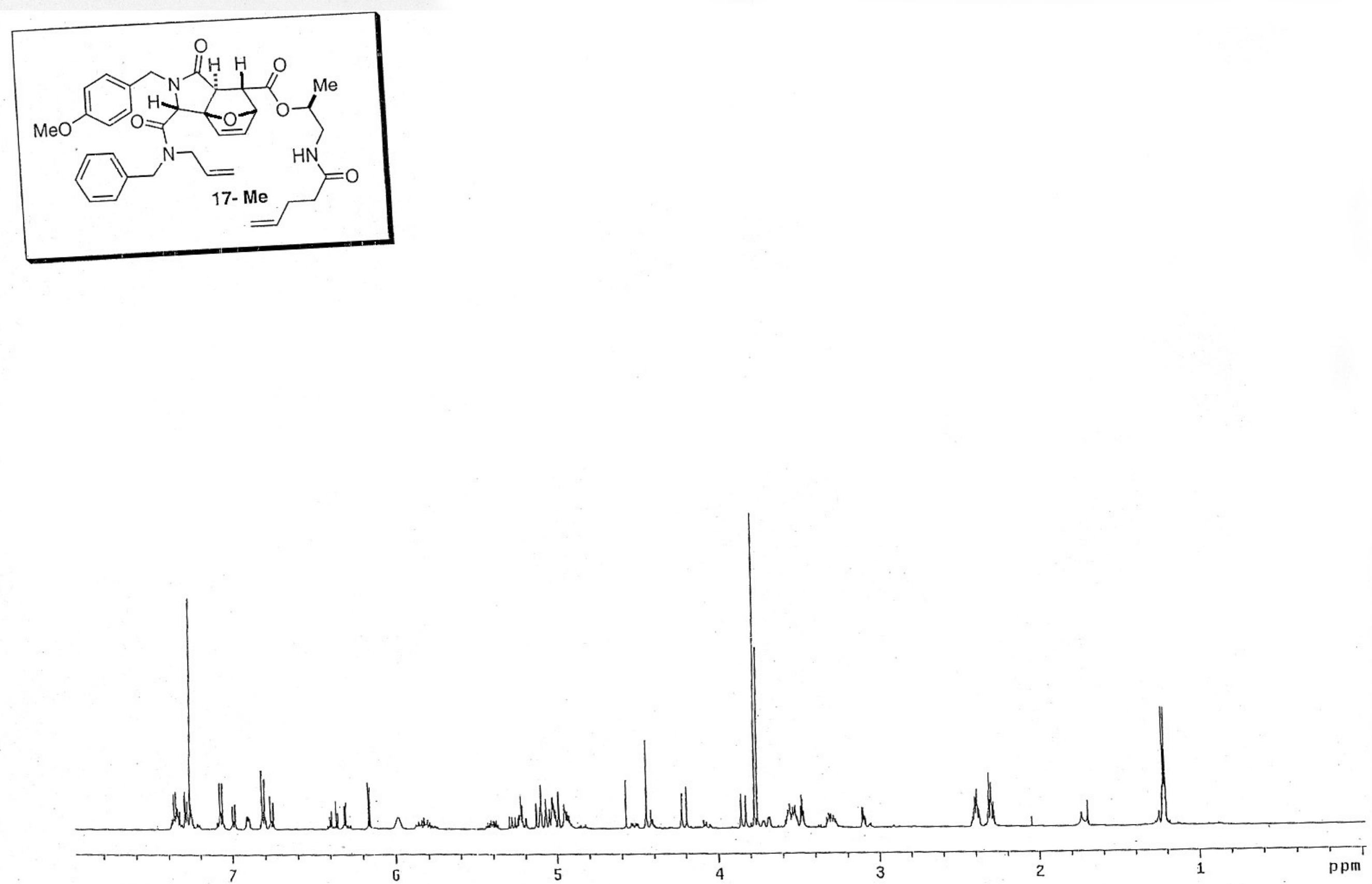



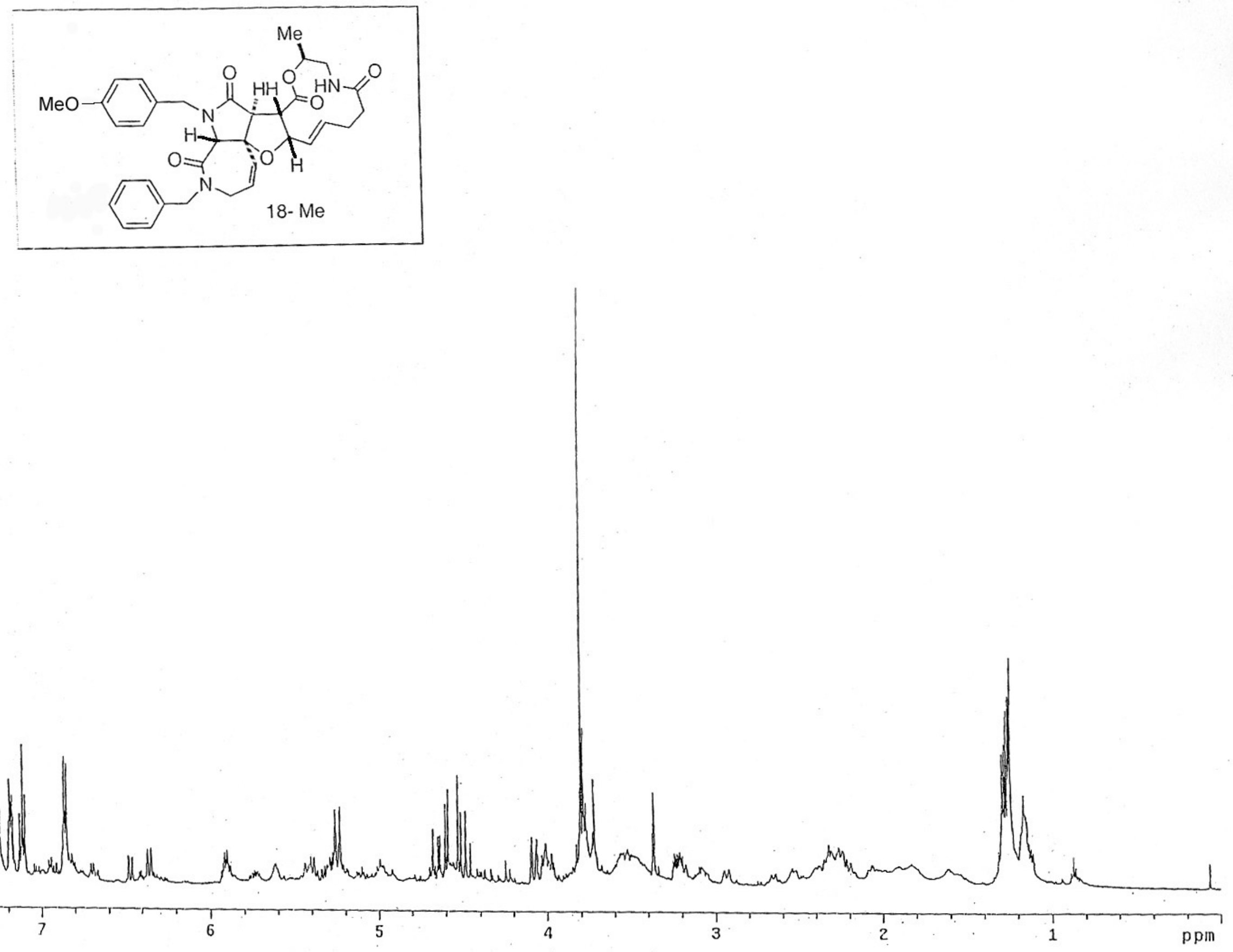

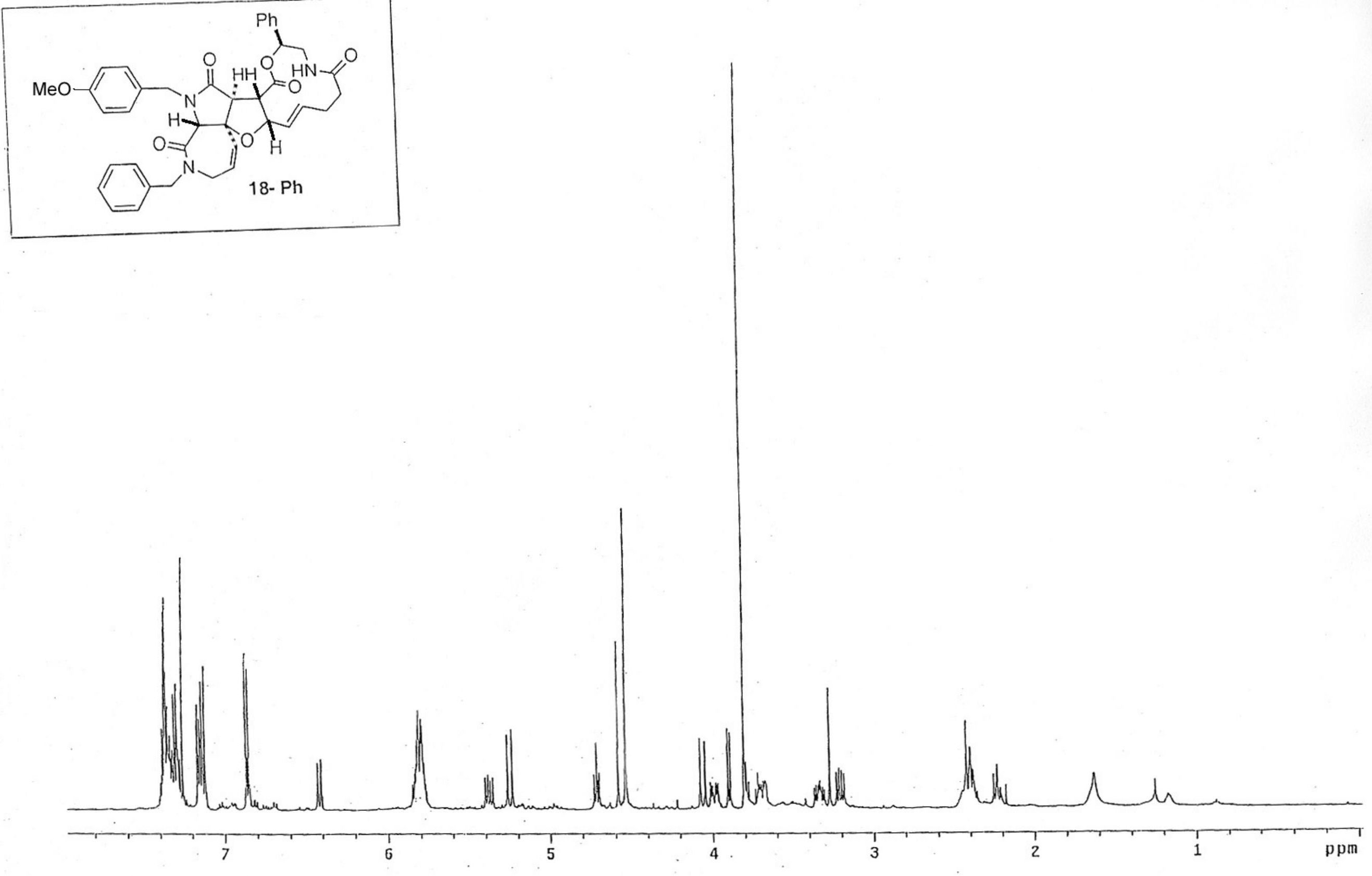


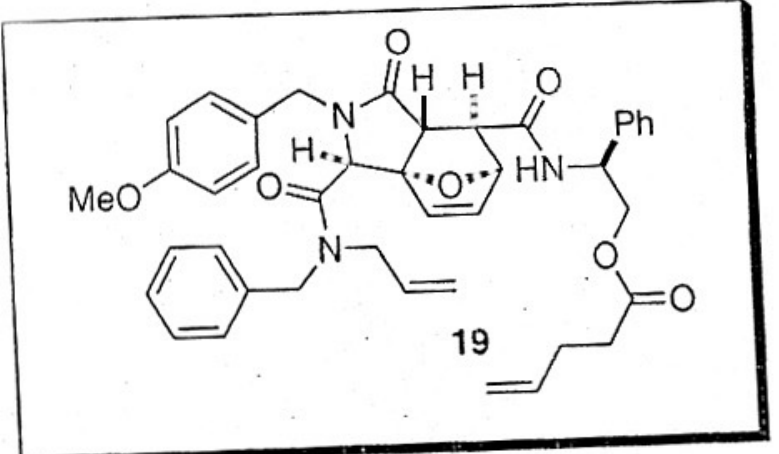




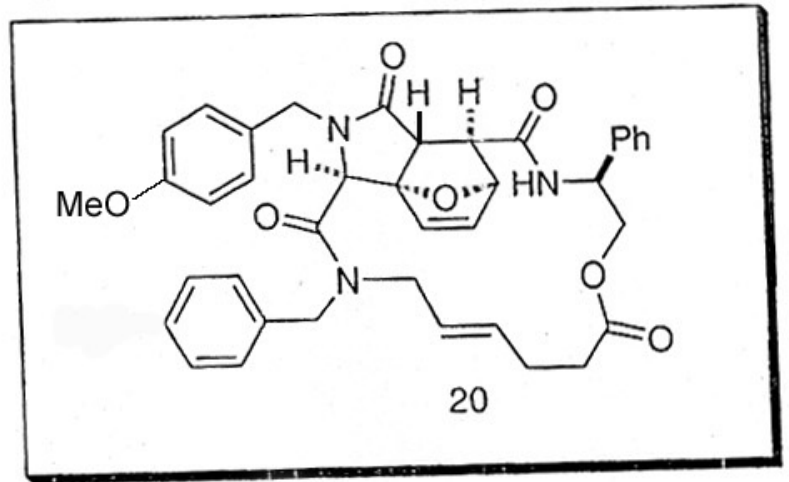



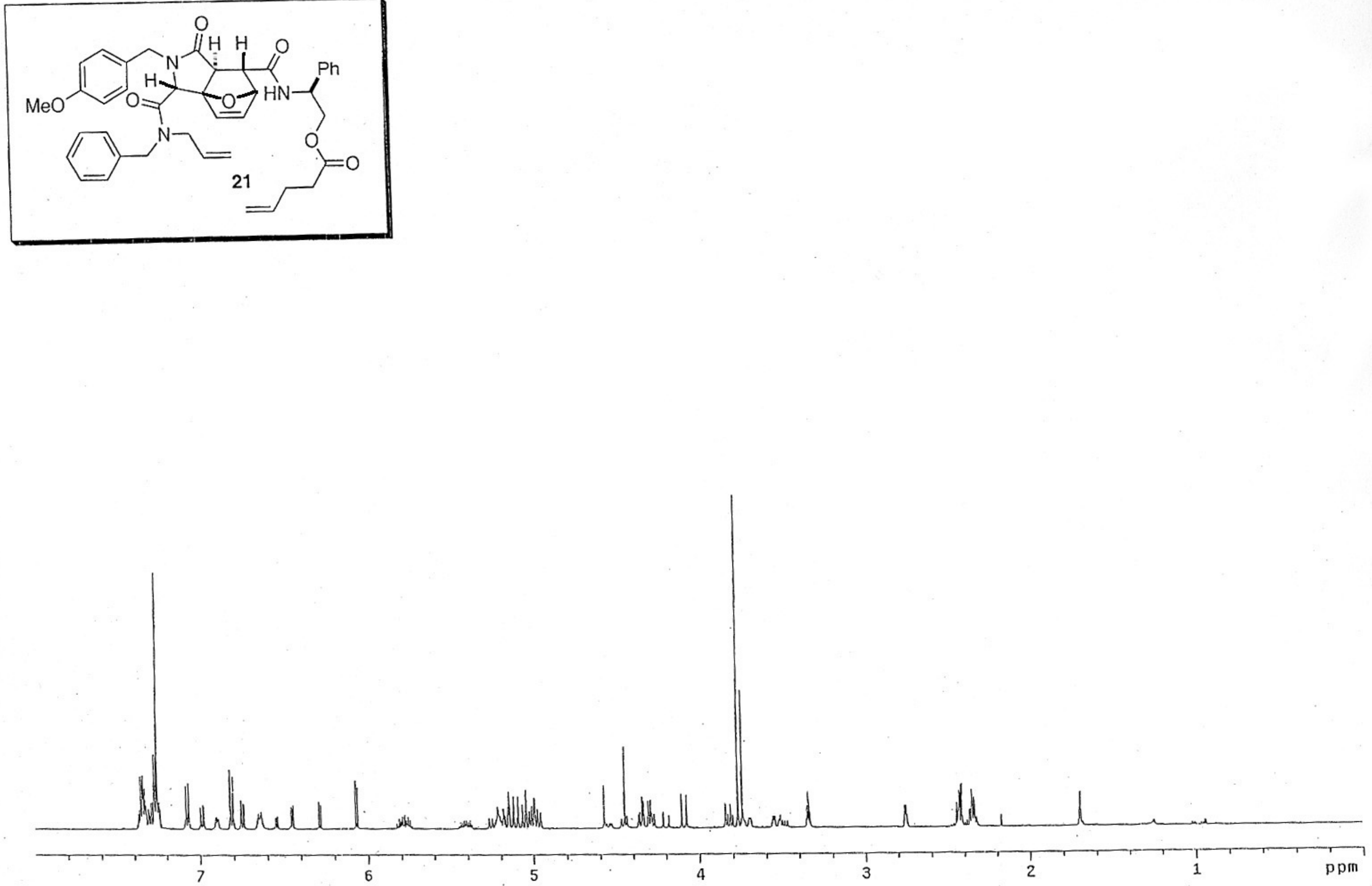

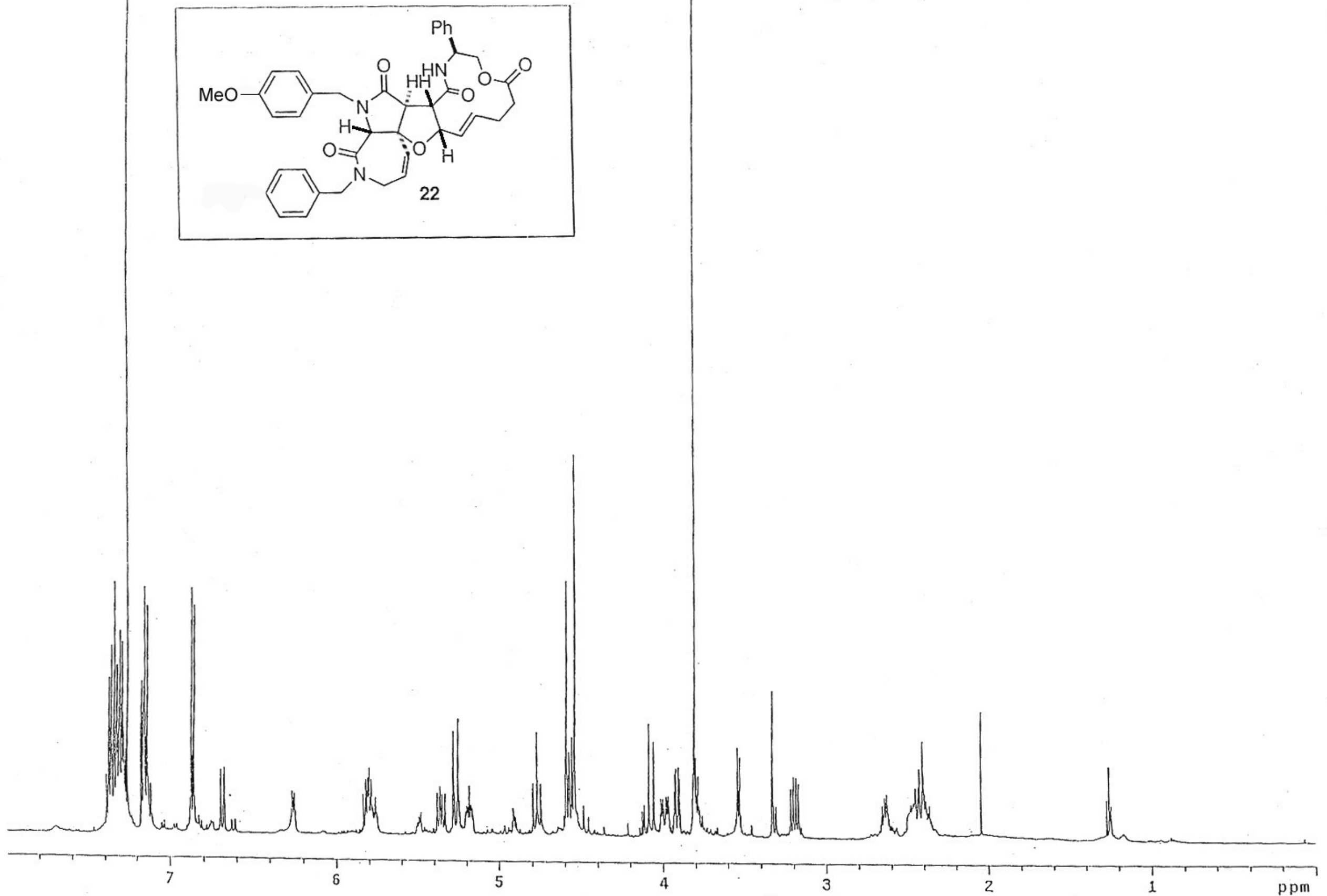